\title{
Effects of multiple stressors on aquatic macroinvertebrate communities in a mixed-land-use watershed
}

Joellen Stivala

jmstivala@mix.wvu.edu

Follow this and additional works at: https://researchrepository.wvu.edu/etd

Part of the Environmental Indicators and Impact Assessment Commons, Environmental Monitoring Commons, and the Water Resource Management Commons

\section{Recommended Citation}

Stivala, Joellen, "Effects of multiple stressors on aquatic macroinvertebrate communities in a mixed-landuse watershed" (2021). Graduate Theses, Dissertations, and Problem Reports. 8236.

https://researchrepository.wvu.edu/etd/8236

This Thesis is protected by copyright and/or related rights. It has been brought to you by the The Research Repository @ WVU with permission from the rights-holder(s). You are free to use this Thesis in any way that is permitted by the copyright and related rights legislation that applies to your use. For other uses you must obtain permission from the rights-holder(s) directly, unless additional rights are indicated by a Creative Commons license in the record and/ or on the work itself. This Thesis has been accepted for inclusion in WVU Graduate Theses, Dissertations, and Problem Reports collection by an authorized administrator of The Research Repository @ WVU. For more information, please contact researchrepository@mail.wvu.edu. 
Effects of multiple stressors on aquatic macroinvertebrate communities in a mixed-landuse watershed

Joellen M. Stivala

\begin{abstract}
Thesis submitted to the
Davis College of Agriculture, Natural Resources, and Design

at West Virginia University

in partial fulfillment of the requirements for the degree of
\end{abstract}

Master of Science

in

Forestry

Kirsten Stephan, Ph.D., Chair

Eric Merriam, Ph.D.

Jason Hubbart, Ph.D.

Division of Forestry and Natural Resources

Morgantown, West Virginia

2021

Keywords: macroinvertebrates, land use, stream condition, impairment, water quality, physical habitat, aquatic ecosystem, environmental stressors, mixed-land-use, urbanization

Copyright 2021 Joellen Stivala 


\begin{abstract}
Effects of multiple stressors on aquatic macroinvertebrate communities in a mixed-landuse watershed
\end{abstract}

Joellen M. Stivala

As urbanization continues, there is a need to identify and understand environmental stressors that impact stream condition in mixed-land-use watersheds. This study analyzed four years of aquatic macroinvertebrate community and environmental data collected from ten sites located at the mouths of first-order tributaries and along the main stem creek of a $23-\mathrm{km}^{2}$, mixed-land-use watershed in central Appalachia. The main objectives were to 1) determine stream ecological integrity by analyzing stream macroinvertebrate taxonomic and trait-based composition and 2) assess which of 23 environmental variables explained significant variability in common community composition metrics (WVSCI, GLIMPSS, Biotic Index, \% clingers, etc.). Results indicated that trait-based metrics had a stronger relationship with land use characteristics compared to taxonomic metrics. Regression analyses and ANOVAs revealed that, across all four years, increased total dissolved solids and conductivity were significant predictors of poor stream condition while increased $\mathrm{pH}$ and \% agricultural land use (within the observed range of $5-26 \%$ ) were significant predictors of improved stream condition. Multivariate analysis indicated that the most impaired sites had the greatest density of National Pollution Discharge Elimination System (NPDES) outlets. Overall, macroinvertebrates were more sensitive to in-stream water chemistry variables compared to physical habitat variables. These findings support the use of aquatic macroinvertebrates to detect environmental stressors in mixed-land-use watersheds. Results indicate that management approaches in West Run Watershed, WV, USA, should focus on storm water management and mitigating the effects of past mining to improve stream condition. 


\section{Acknowledgements}

I would like to thank my advisor, Dr. Kirsten Stephan, for the opportunity to teach, learn, and conduct research under her guidance. Thank you for your patience and commitment to bettering my understanding of the scientific process.

I would also like to thank my committee members Dr. Eric Merriam, for lending his expertise of macroinvertebrates, and Dr. Jason Hubbart, for the inspiration on project development. Gratitude is owed to Dr. Jim Anderson, who granted me access to macroinvertebrates collected in 2016-2018. This project would not be possible without his contribution. Dr. Ida Holaskova deserves major thanks for her dedication to and support of the statistical analysis.

Thank you, Donna Hartman, a mentor that never hesitated to answer any of my insectrelated questions. Her guidance was crucial in learning the identification of macroinvertebrates. I could not have worked on the timeline I did without our lab technician, Abigail Clasgens, who helped sort and identify macroinvertebrates.

Lastly, I would like to thank my family and friends for their endless support throughout this process. A special thank you to my partner, Andrew Hirsch, for constant encouragement and love. I dedicate this work to my grandmother, who empowered me at a young age to follow what makes me happy. I would not have accomplished this without her.

Funding for this project was provided by the Appalachian Freshwater Initiative (National Science Foundation cooperative agreement no. OIA-1458952), the USDA National Institute of Food and Agriculture, Mclntire Stennis Cooperative Research Program (project \# WVA00129), and the West Virginia Agricultural and Forestry Experiment Station. 


\section{Table of Contents}

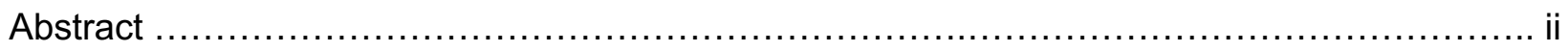

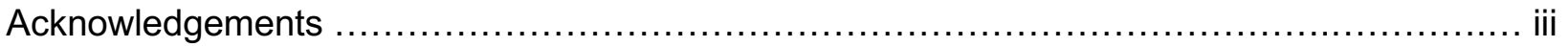



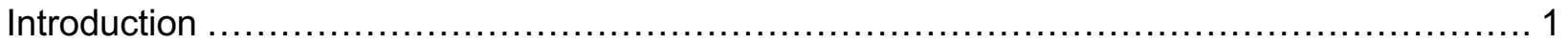

Role of aquatic macroinvertebrates in stream ecosystem function................................... 1

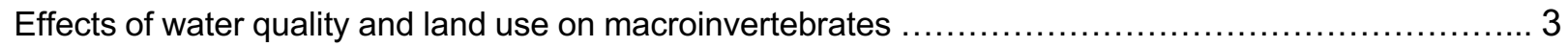



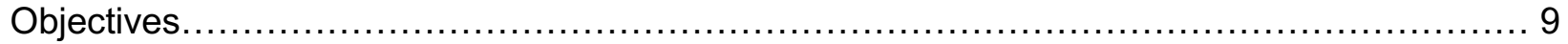

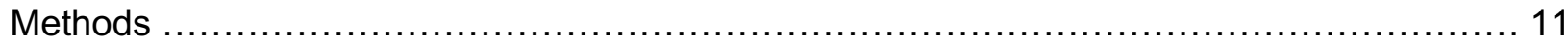

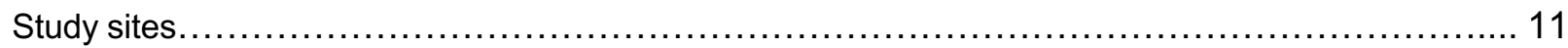

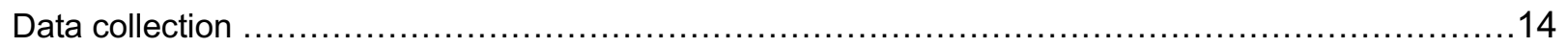

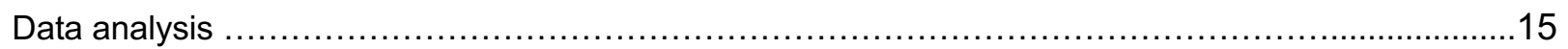

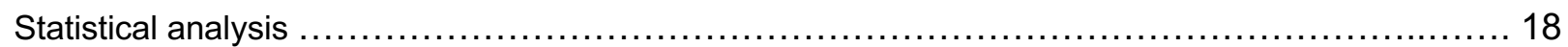

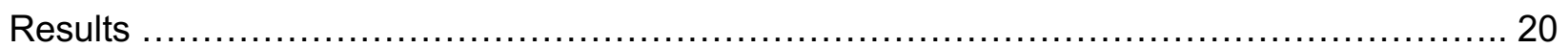

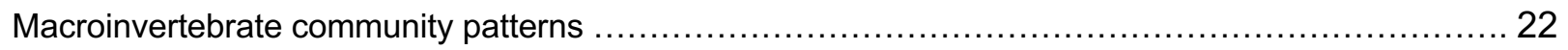

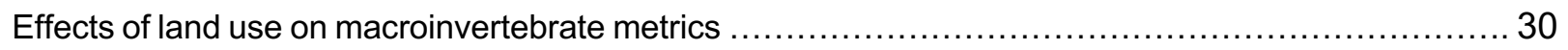

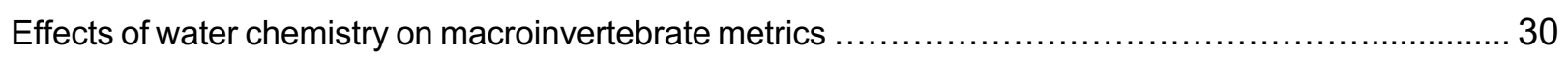

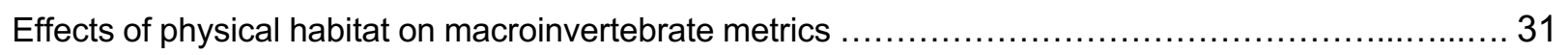

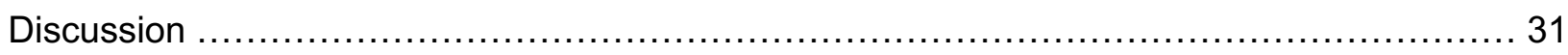

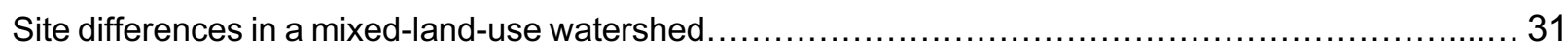



Macroinvertebrate functional traits and response to environmental factors.......................... 34

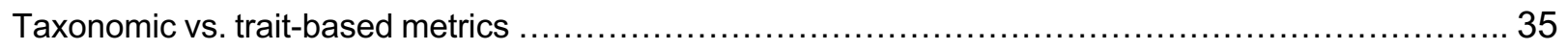



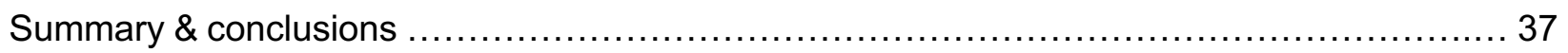

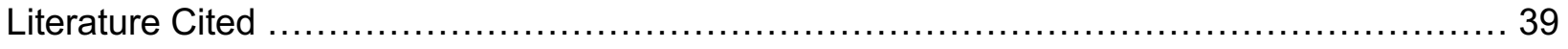

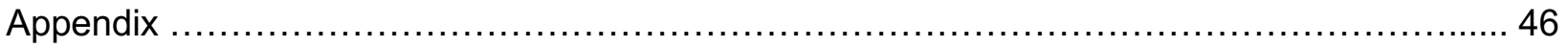

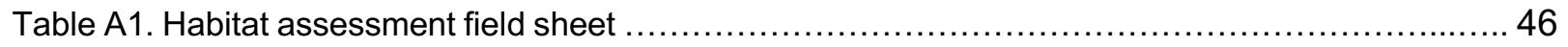

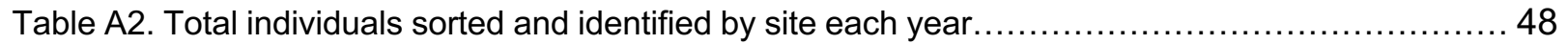

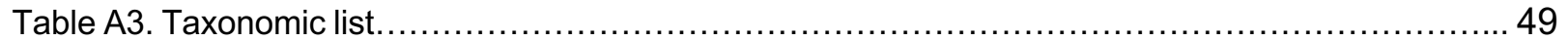

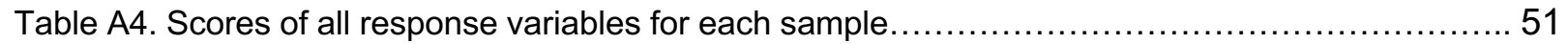



Figure A2. Average relative abundance of families per site of the full dataset.......................... 56

Figure A3-A11. Regressions for WVSCI, GLIMPSS (CF), Family BI, Genus BI, \% Scraper, \% Burrower, $\%$ Clinger, $\%$ Collector-gatherers, $\%$ Collector-filterers, respectively............................ 57 


\section{List of Tables \& Figures}

Table 1. Sample locations with associated sub-watershed land use characteristics 14

Table 2. List of the twenty-three environmental variables and associate definitions.

Table 3. West Virginia specific response variables and definitions ..........................18

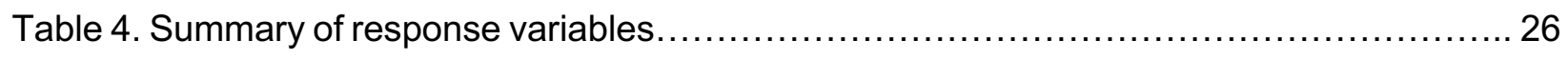

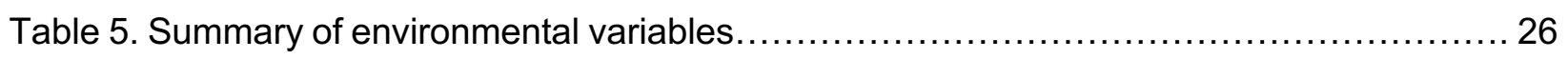

Table 6. Results from the simple regressions and ANOVAs.............................. 27

Table 7. Results from multiple regression backwards elimination............................29

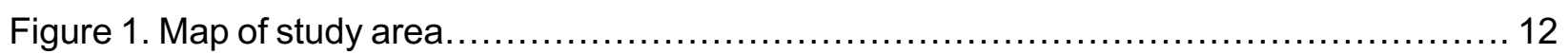



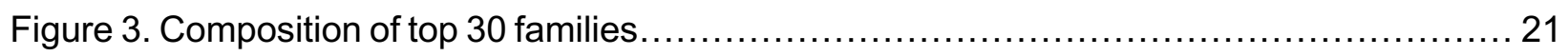

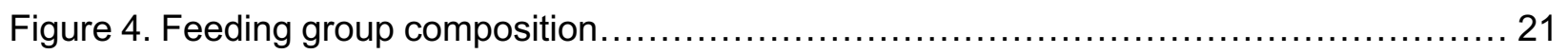



Figure 6. Detrended Correspondence Analysis (DCA) ordination diagram displaying Species

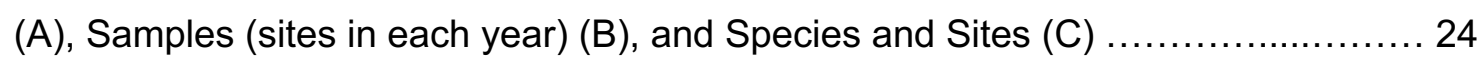

Figure 7. Canonical Correspondence Analysis (CCA) ordination diagrams of environmental variables and macroinvertebrate families $(A)$ and Samples (sites in different

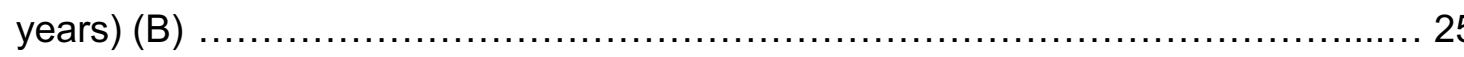




\section{Introduction}

Land use is an important factor in the structure of aquatic communities (Lenat and Crawford 1994). Land use practices can dramatically impact aquatic ecological integrity, i.e., the ability to support the ecosystem's natural range of composition, diversity, and functional organization (Karr 1991). Aquatic ecological integrity (also referred to as stream health or stream condition) supports the provisioning of ecosystem services (Grizzetti et al. 2015) that directly and indirectly benefit human populations (Bolund and Hunhammar 1999). Ecosystem services provided by streams include (but are not limited to) fish production, provisioning of drinking and non-drinking water (e.g., irrigation), and recreation activities (Grizzetti et al. 2015). While these uses tend to involve larger water bodies, small headwater streams typically drain $80 \%$ of the total catchment area (Meyer and Wallace 2001) and, therefore, are a fundamental aspect of aquatic ecosystem service management. Small, low-order streams play an important role in regulating ecosystem services because of the natural processes that occur in them, such as sediment deposition, denitrification, filtering of organic material, and dissolution (MacDonald and Coe 2007). The efficiency of some natural processes tends to decline downstream because, as stream size increases, water velocity increases and benthic frictional resistance decreases, and the ability for pollutants to settle or dissociate decreases (Alexander et al. 2007).

Economic development and human population represent threats to small streams. The environmental impairment of stream health (e.g., via sedimentation, thermal pollution, or chemical pollution) can be particularly severe in urban areas and developing states (Allan 2004). For example, in West Virginia 44\% of streams were designated as impaired in 2016 (WVDEP 2016). In watersheds impacted by human activity, stream condition may be assessed by in-stream response variables (indicators) such as benthic macroinvertebrates (Bonada et al 2006). Since benthic macroinvertebrates reflect their local physicochemical environment, their community structure can be used to assess stream ecological integrity.

\section{$\underline{\text { Role of aquatic macroinvertebrates in stream ecosystem function }}$}

Benthic macroinvertebrates are small aquatic organisms that lack a backbone and are large enough to see with a naked eye. They occur in a variety of waterbodies where they are often found attached to rock substrate, vegetation, or burrowed in sediment. Macroinvertebrates support higher trophic levels (e.g., fish) directly as food source while feeding on lower trophic 
levels, such as, periphyton, algae, plant matter, or other invertebrates (Covich et al. 1999; Cummins 1973). Most macroinvertebrates are primary consumers and detritivores and may be classified into functional groups by feeding type (e.g., shredders, collectors, scrapers). Shredders characteristically feed on large organic matter, collectors feed on fine particulate organic matter, and scrapers feed on periphyton and associated materials on the surface of plants and rocks (Merritt et al. 2019). Functional groups can be broken down further by their feeding mechanism (e.g., filterers or gatherers). Collectors can feed by filtering suspended material (collector-filterers) or by gathering material from sediment deposits (collector-gatherers) (Cummins and Klug 1979; Merritt et al. 2019). Thus, macroinvertebrates are essential in the breakdown of organic matter and the biogeochemical cycling of carbon, nitrogen, and sulfur (Cao et al. 2018). It is estimated that macroinvertebrates can break down up to $73 \%$ of riparian litterfall inputs to streams (Covich et al. 1999). Through the processes of feeding, excretion, and burrowing into sediments, macroinvertebrates release nutrients into the aquatic ecosystem that enhance microbial and plant growth (Covich et al. 1999).

Macroinvertebrates can also be classified by mode of existence or how they maintain their location (termed habit). Habit classification results from the habitat in which macroinvertebrates spend their life. Habitat features, such as sediment size (cobble vs. gravel), lotic or lentic water, or food sources, influence the distribution of macroinvertebrate habits found at a given location (Merritt et al. 2019). Some common habit-trait classifications are skaters, swimmers, clingers, sprawlers, climbers, and burrowers. The presence/absence of certain macroinvertebrate habit traits are indicative of the available habitat in a particular stream. If habitat is altered by environmental factors, environmental impacts can be detected by quantifying macroinvertebrate communities based on trait-based metrics (Poff et al. 2006).

In streams with fluctuating physical conditions (e.g., urban streams), the structural composition of the biotic community is expected to be of great importance in stabilizing the ecosystem's energy flow (Vannote et al. 1980). Structure can be characterized by both taxonomic composition (i.e., richness and relative abundance) and functional traits. A recent study demonstrated that species relative abundance is the key contributor to aquatic ecosystem function, not species richness (Cao et al. 2018). Cao et al. (2018) found that relative abundance of Oligochaeta (worms), dominant taxon, collector-gatherers, and Crustacean/Mollusca affected $\mathrm{N}$ and $\mathrm{P}$ cycling in freshwater streams of southwest China. However, there is also evidence that high macroinvertebrate species richness is essential in maintaining aquatic ecologic integrity (Wallace and Webster 1996). The importance of community composition is demonstrated in the River Continuum Concept (Vannote et al. 1980) that highlights the complementarity of different 
functional groups. In lower-order streams, shredders use specialized feeding appendages to convert large pieces of organic (leaf) litter into smaller fragments that are carried downstream along with fecal remnants. Collectors rely on shredders for the availability of suspended fragments as a food source (Covich et al. 1999). The removal of shredders in an ecosystem may contribute to a cascading effect that results in the loss of other specialized species and a reduction of detrital carbon cycling through the aquatic ecosystem (Covich et al. 1999). Thus, the absence of a particular feeding functional group, or the specific taxa that compose that group, may help managers to identify a possible problem and more aptly mitigate it (Bonada et al. 2006). A major factor influencing the abundance and diversity of macroinvertebrates and the function of aquatic ecosystems is land use due to its effects on water quality and physical habitat.

Effects of water quality, physical habitat, and land use on aquatic macroinvertebrates

Macroinvertebrates are constantly exposed to their physical (e.g., water velocity, sediment) and chemical (e.g., pH, ions) environment. Easily measurable water quality parameters that affect benthic macroinvertebrate composition are temperature, $\mathrm{pH}$, conductivity, and total dissolved solids (TDS) (WVDEP 2018).

\section{Streamwater temperature}

The majority of freshwater organisms are ectothermic. Therefore, temperature fluctuations can have a strong influence on metabolic processes (Hester and Doyle 2011). Changes in stream temperature regimes can be due to topography (geology, aspect, riparian vegetation, land use), streambed characteristics (sediment conduction, groundwater input, hyporheic exchange), and stream discharge (volume, inflow/outflow, turbulence) (Caissie 2006). Slight increases in stream temperature can impact growth and reproduction of organisms (Dodds and Whiles 2010; Hester and Doyle 2011). Sensitive species (Ephemeroptera, Plecoptera) generally have low thermal tolerance while less sensitive species (Diptera, Odonta) have relatively high thermal tolerance (Quinn et al. 1994; Dallas et al. 2012). Previous work showed that increased stream temperatures resulted in decreased macroinvertebrate species diversity (Quinn et al. 1994) and inhibited the ability of scrapers to control periphyton biomass in streams (Caissie 2006). 


\section{Streamwater $\mathrm{pH}$}

Aquatic ecosystems with $\mathrm{pH}$ values of 6.5 to 9 tend to be the most suitable for aquatic life, while a $\mathrm{pH}<4$ and a $\mathrm{pH}>11$ are unsuitable for survival of aquatic life (Boyd 2015). $\mathrm{A} \mathrm{pH}$ outside optimal range lowers invertebrate diversity, impeding energy transfer and nutrient cycling (Dodds and Whiles 2010). In most aquatic ecosystems, $\mathrm{pH}$ is near neutral (Dodds and Whiles 2010), but in forested areas $\mathrm{pH}$ tends to be lower because of the presence of humic acids (Boyd 2015). Humic substances, derived from the decomposition of organic material, generally have a net negative charge, thus, have a strong affinity for hydrogen ions.

Additionally, water bodies in humid areas tend to have lower $\mathrm{pH}$ values due to highly leached soils relative to those located in arid or semi-arid regions or areas dominated by limestone (Boyd 2015). A decrease in pH (acidification) can also result from acid precipitation, increased atmospheric $\mathrm{CO}_{2}$ concentration, acidic runoff (e.g., from mining activities, see below), or acid springs (Dodds and Whiles 2010). If a stream pH $<4.0$ is detected, the stream is considered impaired by the West Virginia Department of Environmental Protection (WVDEP) (Gerritsen et al. 2000).

\section{Conductivity and Total Dissolved Solids}

Conductivity and Total Dissolved Solid (TDS) concentrations impact survival, growth, or reproduction of macroinvertebrate species (Olson and Hawkins 2017). High conductivity (expressed as Specific Conductance (SC) at $25^{\circ} \mathrm{C}$ ) can potentially be toxic to freshwater macroinvertebrates by ions disrupting the water balance of the organism and ion exchange through permeable membranes (Pond et al. 2008). If conductivity of a stream is $>1000 \mu \mathrm{S} / \mathrm{cm}$ it is considered impaired by WVDEP (Gerritsen et al. 2000), but biologic impairment has also been detected at conductivities $>500 \mu \mathrm{S} / \mathrm{cm}$ (Merriam et al. 2011; Cormier et al. 2012). A protective benchmark of $300 \mu \mathrm{S} / \mathrm{cm}$ has been recommended based on the finding that $95 \%$ of genera are prevented from extirpation at or below at $300 \mu \mathrm{S} / \mathrm{cm}$ (Cormier et al. 2012).

Increased SC is one of the most dominant stressors in mining-impacted streams in West Virginia (Pond et al. 2008; Merriam et al. 2011). In Appalachia, changes in macroinvertebrate taxonomic composition have been observed in cases where SC increased by $100-200 \mu \mathrm{S} / \mathrm{cm}$ (Olson and Hawkins 2017). Another study in Nevada, USA, observed a 20\% reduction in taxa abundance when SC increased $300 \mu \mathrm{S} / \mathrm{cm}$ above normal levels (Vander Laan et al. 2013). However, some members of Plecoptera (stoneflies) and Trichoptera (caddisflies) are not strongly affected by TDS concentrations, and Chironomidae (midges), Gastropoda (snails and 
slugs), and Baetidae (small minnow mayflies) tend to have lower fitness at lower SC $(<150-300$ $\mu \mathrm{S} \mathrm{cm}^{-1}$ ) compared to higher SC (>300 $\mu \mathrm{S} \mathrm{cm}^{-1}$ ) (Olson and Hawkins 2017).

TDS is commonly used as a surrogate for specific conductance as they are positively correlated (Boyd 2015). Concentrations of total dissolved solids (TDS) comprise both uncharged molecules (dissolved organic compounds) and ionic compounds (Dodds and Whiles 2010) and are indicative of the degree of mineralization or organic material in the water body (Boyd 2015). In most cases, TDS of freshwater systems is between 500-1,000 mg L-1 (Boyd 2015).

\section{Effects of forested land use on stream macroinvertebrates}

Decreases in forest cover generally result in degradation of macroinvertebrate communities. Compared to all other land uses, forested streams have higher Ephemeroptera (mayflies), Plecoptera, and Trichoptera (EPT) abundance and richness, low Biotic Index (BI; low values indicate the presence of macroinvertebrates that have relatively low tolerance of pollution), and high taxonomic richness (Lenat and Crawford 1994; Riley et al. 2007; Quinn 2000). For example, a study conducted in North Carolina found significantly higher EPT richness and lower BI values in the forested catchment (EPT 29.0, BI 5.60) compared to agricultural $(14.0,6.99)$ and urban $(4.5,7.98)$ catchments (Lenat and Crawford 1994). Of the dominant species present, the forested catchment had a higher percent of collectors (80\%) compared to agricultural (66\%) and urban (56\%) catchments (Lenat and Crawford 1994). Shredders made up a small portion of the community (4\%) in the forested catchment but were absent in the agricultural and urban catchments (Lenat and Crawford 1994). Although the forested catchment in Lenat and Crawford's (1994) study contained $75 \%$ forest cover, $23 \%$ agricultural land, and little new urban development, it still contained more favorable stream conditions for macroinvertebrates relative to the other catchments.

Even in non-forested settings, macroinvertebrates that are sensitive to sedimentation, high temperatures, and low dissolved oxygen respond positively to the presence of riparian forest cover (Chase et al. 2016). In agricultural areas, even minimal riparian tree cover along streams was found to sequester agriculturally derived phosphate $\left(\mathrm{PO}_{4}\right)$, keep water temperatures cool, increase dissolved oxygen, and decrease summer drying of streams (Chase et al. 2016). Previous research suggested that within a highly mixed-land-use watershed, a water temperature tipping point emerges when forested land use drops below $74.2 \%$ (Horne and Hubbart 2020). In urban areas, increased forest cover through riparian buffers along streets reduced urban stream sedimentation and nutrient contamination, and increased groundwater recharge (Matteo et al. 2006). 


\section{Effects of agricultural land use on stream macroinvertebrates}

Streams impacted by agricultural land use tend to have low EPT richness but high taxa richness of more tolerant macroinvertebrates relative to forested streams (Lenat and Crawford 1994). In sites dominated by agricultural land use, macroinvertebrate abundance reaches its peak in the summer season, when the autochthonous energy source, periphyton, is the greatest (Lenat and Crawford 1994). While pasture land has been shown to have lower EPT richness than forested catchments, intense cultivation, such as row cropping, can have a detrimental effect on stream condition relative to pasture land (Allan 2004; Quinn 2000; Storey and Cowely 1997).

Converting previously forested land into row crop agriculture can modify the hydrology by reducing infiltration rates and increasing surface runoff (Chase et al. 2016). In combination with agricultural fertilizers, this commonly results in increased nutrient loading of the stream (e.g., nitrogen, phosphorous, and potassium) (Chase et al. 2016). Large increases of plant nutrients, such as nitrogen and phosphorous, proliferate the production of green plants (taxonomically comprising algae and land plants) that invade macroinvertebrate habitat (Quinn 2000; Riley et al. 2007). Nitrogen fertilizer inputs increase with the percent agriculture per catchment area. In forested catchments of New England, $\mathrm{N}$ inputs into streams were approximately $60 \mathrm{~kg} \mathrm{~km}^{-2} \mathrm{yr}^{-1}$, whereas in a catchment of $35 \%$ agriculture, $\mathrm{N}$ inputs were approximately $1000 \mathrm{~kg} \mathrm{~km}^{-2} \mathrm{yr}^{-1}$ (Boyer et al. 2002). When a threshold of nutrient enrichment is exceeded, eutrophication can occur with excessive aquatic plant growth and subsequent decay depleting stream water dissolved oxygen content. This hypoxia can result in a decline of macroinvertebrates (Riley et al. 2007). However, when less than $30 \%$ of catchment area is in agricultural land use, slight nutrient enrichment in the absence of hypoxia can actually increase the abundance of sensitive taxa due to stimulating the growth of the primary feeding source, periphyton (Riley et al. 2007).

While agriculture negatively impacts benthic macroinvertebrate assemblages, it does so to a lesser extent than urban land use (Riley et al. 2007). Receiving waters surrounded by agricultural land use areas can still support a number of tolerant taxa, whereas receiving waters in urban land use areas tend to have lower total taxa richness (Lenat and Crawford 1994). When comparing land use impacts using the Biotic Index (BI), forested streams generally score a low $\mathrm{BI}$ rating which indicates good water quality, agricultural streams score fair water quality, and urban streams score poor water quality (Lenat and Crawford 1994). 


\section{Effects of urban land use on stream macroinvertebrates}

The impacts of urbanization can influence streams both locally and over distance (Allan 2004). Urbanization has been shown to alter water quality by intensifying hydrologic regimes due to increased area of impervious surfaces, resulting in increased runoff and pollutant varieties, and increased temperature due to lack of riparian vegetation and warmed surface runoff. Increased water temperatures generally result in decreased available dissolved oxygen in the water (Riley et al. 2007). Urban areas tend to have increased SC, primarily due to high concentrations of chloride (Cormier et al. 2013). As impervious surfaces cause runoff to reach stream segments more quickly, increased flows following precipitation events cause exposed subsoils, channelization, and bank erosion which results in sedimentation and enrichment of ferrous iron and precipitates (Allan 2004; Sheldon 2019).

Increased sedimentation negatively impacts aquatic macroinvertebrates because small particle deposits fill interstitial spaces where these organisms live and feed (Roy et al. 2003). In addition, as the small sediment particles clog the streambed, the flow of water through gravel and cobble habitat is impeded. This decreases oxygenation, thus making the habitat unsuitable for macroinvertebrates and fish (Dodds and Whiles 2010). Excess sediments also block light for primary production and increase scour, thereby reducing biodiversity of macroinvertebrates (Dodds and Whiles 2010). Researchers have determined that potential destabilization of streams (i.e., bank erosion, stream bed and channel morphology alteration) occurs with impervious surfaces as low as $5-20 \%$ of total catchment area (Poff et al. 2006). This is consistent with declines in benthic community indices when the percent of impervious surface is greater than 8-15\% (Riley et al. 2007; Roy et al. 2003).

\section{Effects of mining land use on stream macroinvertebrates}

In central Appalachia, mining is a common land use which can significantly impact macroinvertebrate communities by increasing SC (Pond et al. 2008) and by lowering pH. In fact, specific conductance is highly correlated with the percentage of mining per catchment. Merriam et al. (2011) found that, on average, $26 \%$ of mining land use per catchment corresponded to a conductivity of $257 \mu \mathrm{S} \mathrm{cm}^{-1}$, and $62 \%$ of total mining land use corresponded to conductivities of $541 \mu \mathrm{sm}^{-1}$. In the Appalachian region of West Virginia, biologic impairment in streams tends to occur when mining land use is between $10 \%$ and $30 \%$ of total catchment area (Petty et al. 2010; Merriam et al. 2011). Mining-related land use can lead to increased SC due to increased dissolved ion concentrations of bicarbonate, chloride, and sulfate (Cormier et al. 2013). A legacy effect of mining activity, Acid Mine Drainage (AMD), is a result of the exposure of minerals 
(sulfides) to oxygen and water. This process produces an often-acidic solution that is high in sulfate and other dissolved metals (Al, Fe). In some cases, the surrounding geology (i.e., limestone) can buffer the acidity to mitigate the effects. However, this is not the case in areas where the surrounding geology is sandstone, and AMD-impacted streamwater therefore has low $\mathrm{pH}$. Ephemeroptera are found to be the most intolerant taxa to mining impacts in central Appalachia (Pond et al. 2008). Mining-related pollutants (Al, Fe, Mn, Ni, sulfate, SC) were the main factors impacting macroinvertebrate community composition (WVSCl) in Cheat River watershed, West Virginia (Freund and Petty 2007).

$\underline{\text { Use of macroinvertebrates as indicators of stream ecological integrity }}$

Macroinvertebrate community composition can serve as an indicator of stream condition because of macroinvertebrates' close relationship with the environment in which they spend all or part of their life cycle (Beasley and Kneale 2002). These organisms are commonly used in biomonitoring because of their high abundance, wide variety of taxa, and lack of mobility (Purcell et al. 2009). Assessing macroinvertebrate composition allows managers to evaluate stream condition using a wholistic approach that incorporates both biotic and abiotic factors over time. The use of macroinvertebrates as biological indicators is effective because different taxa have different tolerances to pollution (Bonada et al. 2006). Taxa that are present in a stream, thus, reflect the water quality (degree of pollution) of the stream. Tolerance values have been determined by measuring taxa's resistance to either dissolved oxygen (DO) deficits (Chang et al. 2014), organic pollution (Hilsenhoff 1987), or metals (Cd, Cu, Zn) (Clements 1999). Despite these different methods, most tolerance value designations are statistically valid worldwide because of the high correlation among them (i.e., as organic pollution increases, DO decreases) (Chang et al. 2014). Species found only in excellent water quality (no apparent organic pollution) would score a low tolerance value (0-1); species found in highly polluted water would score the highest values (9-10). Worms (Oligochaeta) or midges (Chironomidae) generally have high tolerance values, while mayflies (Ephemeroptera), stoneflies (Plecoptera), and caddisflies (Trichoptera) (EPT) generally have low tolerance values. Therefore, the total number of EPT insect taxa is commonly used as a community-level indicator of stream health (Dodds and Whiles 2010). For example, in WV's undisturbed streams, Ephemeroptera account for $25-50 \%$ of total macroinvertebrate abundance and are therefore an appropriate bioindicator of richness and composition metrics throughout the state (Pond et al. 2008). When tolerance values for all individuals in a community are averaged, they yield the Biotic index (BI) (Hilsenhoff 1987). BI 
values can be combined with other metrics to perform bioassessments that inform managers on threshold pollution levels.

While biomonitoring programs and regulatory assessments commonly use tolerance values as the basis of their assessments, limitations exist in using this approach as tolerance of pollution can vary regionally due different geographic and climatic conditions (Chang et al. 2014). Many states have therefore developed regional tolerance values to increase the reliability of using macroinvertebrates as water quality indicators (Chang et al. 2014). Tolerance values used in West Virginia were specifically designated for the state by the West Virginia Department of Environmental Protection (WVDEP) Watershed Assessment Branch (WVDEP 2018). These tolerance values are a component in calculating the West Virginia Stream Condition Index (WVSCI) and Genus Level of Most Probable Stream Status (GLIMPSS) used by WVDEP to assess stream health.

Trait based functional groups are commonly used in regional indices (GLIMPSS) and quantified in much of the literature because these groups respond to their environment in a predictable way. For example, in a previous studies, clingers and scrapers declined with increased sedimentation, whereas burrowers increased in response to sedimentation (e.g., Richards et al. 1997; Nichols et al. 2016). Additionally, scrapers and clingers were used in GLIMPSS (CF) PL and represent the most sensitive, responsive, and non-redundant metrics in each functional group (Pond et al. 2011). In a similar study to the current, collector-gatherers and collector-filterers were used based on the expectation that they increase and decrease, respectively, in response to disturbance (Nichols et al. 2016). Unlike collector-filterers, many collector-gatherers tend to be tolerant to disturbance (i.e., Chironomidae) and increase as you move downstream due to abundant food resources (Fu et al. 2016). Collector-filterers have been found in greater proportions in forested lower-order streams (Fu et al. 2016).

\section{Objectives}

Within mixed-land-use watersheds, researchers have observed significant differences in physicochemical water quality regimes between monitoring sites, even when in close proximity (Kellner et al. 2018; Chase et al. 2016). However, macroinvertebrate communities have rarely been investigated in these settings. Thus, there is a need to quantitatively describe macroinvertebrate communities at a single-stream scale to better understand the complexities of interacting land uses, as shown in seminal work by Nichols et al. (2016). Connecting land use and associated environmental variables to stream condition can help scientists to identify 
stream health thresholds and managers to allocate resources more efficiently to conserve water resources or devise regulations to guide future development. This study will help managers target environmental stressors that are contributing to the impairment of stream condition by using aquatic benthic macroinvertebrates as bioindicators.

The overall goal of this project is to investigate differences in macroinvertebrate communities between sub-catchments with variable forest cover, agricultural land, urban area, and mining influence in a mixed-land-use watershed. The specific objectives are A) to quantify aquatic macroinvertebrate taxonomic composition and trait-based composition, and B) to determine the environmental variables that influence macroinvertebrate community composition as characterized by 1) commonly used indices, 2) feeding-group composition (scrapers, collector-filterers, collector-gatherers), and 3) macroinvertebrate habit (clingers, burrowers). The following hypotheses were tested:

1. $H_{0}$ : There is no significant correlation between macroinvertebrate indices (BI, WVSCl, GLIMPSS (CF)) and environmental variables.

$H_{a}$ : Macroinvertebrate indices correlate negatively (BI) or positively (WVSCI, GLIMPSS $(C F)$ ) with environmental variables becoming more favorable (e.g., increased forest cover, decreased embeddedness).

2. $H_{o}$ : There is no significant correlation between macroinvertebrate feeding group composition (scraper, collector-filterers, collector-gatherers) and environmental variables. $H_{a}$ : Scrapers and collector-gatherers increase and collector-filterers decline as environmental variables indicate more development (increased developed land cover, higher TDS).

3. $H_{0}$ : There is no significant correlation between macroinvertebrate habit type composition (clingers, burrowers) and environmental variables.

$H_{a}$ : Burrowers increase and clingers decline as environmental variables indicate more development. 


\section{Methods}

\section{Study Sites}

This study was conducted in West Run Watershed (WRW), Monongalia County, West Virginia. WRW represents a mixed-land-use watershed comprising $50 \%$ forest (oak-dominated mixed hardwoods), $19 \%$ urban/suburban development, and $23 \%$ agriculture in a small catchment of $23 \mathrm{~km}^{2}$ (Kellner et al. 2018) (Figure 1). Rapid development and historic mining within WRW has caused West Run to be listed as a 303d impaired stream in 2012, 2014, and 2016 (WVDEP 2012, 2014, 2016).

For the current investigation, ten study sites were established along perennial tributaries or the main stem of West Run (Figure 1; Figure 2). Each study site represented a subwatershed comprising differing proportions in forested, agricultural, developed (urban), and barren (mining) land use (Table 1). Land use was extracted from the most current, 2016 National Agricultural Imaging Program (NAIP) (Strager and Maxwell 2018) and analyzed in ArcGIS (Version 10.5, Esri Inc., Redlands, CA, USA, Copyright (C 2016). The land use dataset includes 25 land cover classes, but only 16 are present in WRW (Figure 1). For this study, land cover classes were reduced to four categories to be consistent with previous studies (Kellner et al. 2018; Nichols et al. 2016; Peterson and Hubbart 2020) (using developed, forest, agriculture categories) and to capture mining influence (barren category). The developed category includes roads, impervious surfaces, and mixed development. The forest category represents small stream riparian habitat, other forests, mixed mesophytic forests, dry-mesic oak forests, and dry oak (oak-pine) forests. The agriculture category includes low vegetation, hay/pasture, and cultivated crops. The barren category includes barren (bare soil, quarries, surface mine features) and mine grass classes (i.e., WV mine permit polygon boundaries overlapped with low vegetation). In addition to quantifying percent land use for each sub-watershed, land use was also quantified within a 5-ha riparian buffer extending $500 \mathrm{~m}$ upstream (with a width of $50 \mathrm{~m}$ on both sides of the stream) from each study site. National Point Discharge Elimination System (NPDES) permit densities per sub-watershed were calculated to assess the impact of mining and non-mining point sources entering the stream on macroinvertebrate community composition (WVDEP 2020). 



Figure 1. Land cover distribution in WRW derived from the National Agricultural Imaging Program (NAIP). Sub-watersheds were delineated based on ten pour points that correspond to sample locations. Sites 1, 3, 5, 7, 8 and 10, located on the mainstem (round symbols), include all upstream influences (displayed in bold outline). Sites 2, 4, 6, and 9 are sites along tributaries (square symbols). Land use / Land cover $\square$ Barren

$\square$ Cultivated Crops

e) Forests $\square$ Mixed Development 



Figure 2. Photographs of site locations taken in spring 2021. Pictures were taken looking upstream from the start of the reach. 
Table 1. Sample locations with associated sub-watershed land use characteristics (NAIP 2016).

\begin{tabular}{llllll}
\hline Site & Area $\left(\mathrm{km}^{2}\right)$ & Agriculture $(\%)$ & Barren $(\%)$ & Developed $(\%)$ & Forest $(\%)$ \\
\hline 1 & 2.6 & 14 & 8 & 14 & 64 \\
2 & 0.4 & 16 & 10 & 12 & 61 \\
3 & 3.9 & 17 & 10 & 11 & 61 \\
4 & 2.8 & 22 & 12 & 16 & 50 \\
5 & 11.4 & 25 & 11 & 15 & 48 \\
6 & 3.7 & 26 & 6 & 10 & 57 \\
7 & 17.1 & 25 & 11 & 15 & 48 \\
8 & 20.3 & 23 & 12 & 17 & 48 \\
9 & 3.2 & 5 & 40 & 52 & 3 \\
10 & 25.1 & 19 & 16 & 22 & 43 \\
\hline
\end{tabular}

Data Collection

Field Collection

Macroinvertebrates were collected once annually in fall months (October or November) of 2016, 2017, 2018, and 2019 following West Virginia Department of Environmental Protection (WVDEP) protocol (WVDEP 2018). A team working on the Appalachian Freshwater Initiative collected the $2016-2018$ samples. Using a rectangular-frame $0.25-\mathrm{m}^{2}$ kick net, one kick was carried out at each of four different riffles per site to total $1 \mathrm{~m}^{2}$ of sample kick area per site. The four riffles were selected to represent the best available habitat within a 100-meter reach. For each site, the four kick samples were combined into one site sample. Large debris was inspected and removed from the sample before transferring macroinvertebrates to a container containing $75 \%$ ethanol. Immediately before macroinvertebrates were collected, water quality parameters (i.e., pH, conductivity, temperature, and TDS) were measured using a YSI (YSI Inc., Yellow Springs, OH) or Oakton PCTS 50 (Oakton Instruments, Vernon Hills, IL) pocket tester. Visual habitat assessments were conducted at each site using the Environmental Protection Agencies (EPA) high gradient field sheet (Table A1) (Barbour et al. 1999). The habitat assessment evaluates the condition of ten in-stream and riparian area parameters on a scale from 0 (poor) to 20 (optimal) (Table A1). The scores from all habitat parameters can then be totaled to get an overall habitat score of the sample location.

\section{Lab Processing}

In-lab processing consisted of sorting (picking) and identifying benthic macroinvertebrates according to WV DEP protocol (WVDEP 2018). To obtain a randomized subsample of 200 individuals (+/- 20\%), a site sample is poured into a Gridded Sorting Tray with 
cells (1 inch $\times 1$ inch) numbered 1-100. The tray is filled halfway with water to allow the sample to disperse across the tray. Using a random number generator, one cell is selected and all macroinvertebrates are picked out and placed in a vial of ethanol. This process is repeated until a subsample of $200( \pm 20 \%)$ individuals is reached. In samples with a high abundance of macroinvertebrates, a minimum of four grid cells still needs to be processed, even if the subsample is then larger than 200 . In this study, one subsample was generated per site sample (Table A2); for each year, subsamples were generated by different personnel. Individuals in subsamples were identified to genus level (Figure A1), if possible, using Merritt et al. (2019) by two closely collaborating personnel in 2020.

\section{Data Analysis}

For each of the four annual samples per site, macroinvertebrate taxonomic composition was quantified via the West Virginia Stream Condition Index (WVSCl; Gerritsen et al. 2000), Genus Level of Most Probable Stream Status (GLIMPSS; Pond et al. 2011), and Hilsenhoff Biotic Index (Hilsenhoff 1987). In addition, community composition was assessed by quantifying the proportions of family and genus-level functional feeding groups and habits. Twenty-three environmental variables (Table 2) were used as independent variables.

Hilsenhoff Biotic Index (BI) was calculated based on macroinvertebrate composition and abundance at family and genus level (Family BI, Genus BI). The Hilsenhoff BI uses published tolerance values (Barbour et al. 1999; Merritt et al. 2019) of the macroinvertebrate taxa present and a weighted relative abundance to classify stream condition. Hilsenhoff's equation is:

$$
B I=\frac{\sum n_{i} n_{a}}{N}
$$

where $n_{i}$ represents the number of macroinvertebrates in each taxon, $n_{a}$ represents the tolerance values of the taxa, and $\mathrm{N}$ represents the total number of macroinvertebrates in the sample (Hilsenhoff 1987). Low values (0.00-3.50) correspond to excellent water quality and an unlikely degree of organic pollution, whereas higher values (8.51-10) correspond to very poor water quality and a likely degree of severe organic pollution. As mentioned previously, while BI is based on tolerance of organic pollution or low DO, it has been shown to be robust across a range of water quality measures (Chang et al. 2014).

Agencies in West Virginia commonly use WVSCI and GLIMPSS to evaluate stream health. Both indices are composite indices, averaging core metrics to quantify stream condition (Table 3) (Gerritsen et al. 2000; Pond et al. 2011). After calculating individual core metrics, each 
core metric is standardized using best standard values (BSV) (Gerritsen et al. 2000; Pond et al. 2011). Standardization corrects the direction of impairment and rescales the scores to range from 0 (worst) to 100 (best). WVSCl core metrics are family richness, EPT richness, \% EPT, \% Chironomidae, \% dominant two families, and family-level BI (Table 3). After averaging these core metrics, the resulting WVSCI value is then compared to reference conditions of unimpaired (>68), impaired-grey zone (60.6 - 68), or impaired-poor (<60.6) stream health. GLIMPSS is regarded as an improved index compared to WVSCI because it accounts for seasonal and regional differences and provides greater scope of represented taxa (genus-level) which yield greater detection of impacts (Pond et al. 2012). In this study, GLIMPSS with Chironomidae Family (CF) for the Western Allegheny Plateau ecoregion and summer seasonality (PL Su) was used. Although GLIMPSS (CF) is modified by not identifying Chironomids to genus, it has been found to be highly suitable in bioassessments and, in some cases, to perform slightly better than GLIMPSS (Pond et al. 2012). Core metrics composited into GLIMPSS (CF) are genus-level BI, total number of genera, number of intolerant genera with tolerance value $(T V)<3$, number of Ephemeroptera genera, total number of clinger genera, total number of scraper genera, \% dominant five genera, and \% Chironomidae (Table 3). The stream health scoring criteria using GLIMPSS (CF) PL Su are very good ( $\geq 70)$, good (62-69), degraded (31-61), and severely degraded (<31). It should be noted that most samples (25 of 36 ) in this study were collected in November, which is outside the timeframe (April - October) prescribed for quantifying WVSCI and GLIMPSS (CF) PL Su. Since both WVSCI and GLIMPSS Su indices are calibrated for AprilOctober months, the final scores for these sites are considered not comparable to the reference rating system (Gerritsen et al. 2000; WVDEP 2018), i.e., sites in this study were not rated "very good", "good", etc. However, considering that the seasonal taxonomic composition resembles summer composition of prior studies (Greg Pond, pers. Comm.), scores for both WVSCI and GLIMPSS (CF PL Su) were used as a response variable in this study to compare the different sites.

Trait-based metrics were represented by genus-level feeding mechanisms (scrapers, collector-gatherers, collector-filterers) and genus-level habit (burrowers, clingers). These metrics were derived from the Regional Tolerance Values, Functional Feeding Groups, and Habit/Behavior Assignments for Benthic Macroinvertebrates table in the Rapid Bioassessment Protocols For Use in Streams and Wadeable Rivers (Barbour et al. 1999). If mechanisms were not specified in Barbour et al. (1999), then Merritt et al. (2019) was used. Taxa that could not be classified (e.g., unknown Coleoptera) were left out of the dataset. Trait-based metrics were 
expressed as the relative abundance of the genera of interest (e.g., number of scraper genera / total classified genera).

Table 2. Environmental variables used in analyses. Land use/land cover variables were used both within the subwatershed and the 5-ha riparian buffer zone. Expected response (arrows) predicts the response of stream condition to an increase in habitat parameter (0-20, where 20 is optimal), values of water quality parameters, and proportion of land cover type. An increase in habitat parameter scores will improve stream condition. With an increase in $\mathrm{pH}$, stream condition may improve or deteriorate depending on whether $\mathrm{pH}$ is changing toward or away from optimal values.

\begin{tabular}{|c|c|c|}
\hline Environmental variables & Definition & $\begin{array}{l}\text { Expected } \\
\text { response }\end{array}$ \\
\hline Habitat parameter & (Barbour et al. 1999) & \\
\hline $\begin{array}{l}\text { Epifaunal Substrate/ Available } \\
\text { Cover }\end{array}$ & $\begin{array}{l}\text { Relative quantity and variety of natural structures (cobble, woody } \\
\text { debris, large rocks, undercut banks) }\end{array}$ & $\Delta$ \\
\hline Embeddedness & $\begin{array}{l}\text { Extent to which substrates are sunken into the stream; the lower } \\
\text { the embeddedness, the higher the habitat parameter score }\end{array}$ & $\boldsymbol{\Delta}$ \\
\hline Velocity / Depth Regime & $\begin{array}{l}\text { The occurrence of slow-deep, slow-shallow, fast-deep, fast- } \\
\text { shallow regimes }\end{array}$ & $\Delta$ \\
\hline Sediment Deposition & $\begin{array}{l}\text { The amount of sediment accumulated and consequences (point } \\
\text { bars); the lower the sediment deposition, the higher the habitat } \\
\text { parameter score }\end{array}$ & $\Delta$ \\
\hline Channel Flow Status & The amount of water that fills the channel & $\Delta$ \\
\hline Channel Alteration & $\begin{array}{l}\text { Large-scale changes in the shape of the stream channel (riprap, } \\
\text { artificial embankments present); the lower the channel alteration, } \\
\text { the higher the habitat parameter score }\end{array}$ & $\boldsymbol{\Delta}$ \\
\hline Frequency of Riffles (or Bends) & The occurrence of riffles in the stream & $\Delta$ \\
\hline Bank Stability & The degree of erosion or potential for erosion on stream banks & $\Delta$ \\
\hline Vegetative Protection & $\begin{array}{l}\text { The amount of vegetative protection on the stream bank or } \\
\text { nearby portion of the riparian zone }\end{array}$ & $\Delta$ \\
\hline Riparian Vegetative Zone Width & $\begin{array}{l}\text { The width of vegetation from the stream bank to the end of the } \\
\text { riparian zone }\end{array}$ & $\Delta$ \\
\hline \multicolumn{3}{|l|}{ Water quality parameters } \\
\hline $\mathrm{pH}$ & Measures the acidity or basicity of the water & $\Delta \nabla$ \\
\hline Total Dissolved Solids (TDS) & The amount of suspended dissolved material (g/L) & $\boldsymbol{\nabla}$ \\
\hline Conductivity & Measures the ability of water to pass electrical flow & $\boldsymbol{\nabla}$ \\
\hline NPDES & Density of discharge outlets (i.e., stormwater, wastewater) & $\boldsymbol{\nabla}$ \\
\hline NPDES Mining & Density of mining related discharge outlets & $\boldsymbol{\nabla}$ \\
\hline Land use / land cover (\%) & (Strager and Maxell 2018) & \\
\hline Forested & $\begin{array}{l}\text { Small stream riparian habitats, mixed mesophytic forests, dry- } \\
\text { mesic oak forests, dry oak ( pine) forests, and other forests }\end{array}$ & $\Delta$ \\
\hline Agriculture & Low vegetation, hay/pasture, and cultivated crops & $\nabla$ \\
\hline Developed & Roads, impervious, and mixed development & $\nabla$ \\
\hline Barren & Barren and mine grass & $\boldsymbol{\nabla}$ \\
\hline
\end{tabular}


Table 3. Stream condition indices derived from stream macroinvertebrate communities used in this study. West Virginia-specific WVSCI is a family-level composite index and West Virginia-specific GLIMPSS (CF) is a composite genus-level index; the six or eight respective components of each index are averaged to calculate the index. GLIMPSS (CF) metrics are specific to the Western Allegheny Plateau and summer seasonality.

E - Ephmeroptera (mayflies), P - Plecoptera (stoneflies), T - Trichoptera (caddisflies), HBI - Hilsenhoff Biotic Index.

\section{Stream Condition Index Definition}

\section{West Virginia Stream Condition Index - WVSCI:}

Taxa richness

EPT richness

$\%$ EPT

$\%$ Chironomidae

$\%$ Dominant 2 taxa $\mathrm{HBI}$
Count of all families in the sample

Sum of individuals in Ephemeroptera, Plecoptera, Trichoptera

Relative abundance of individuals in the orders $E, P$, and $T$

Relative abundance of individuals in the family of non-biting midges

Relative abundance of individuals in the top 2 dominant taxa

Average abundance-weighted tolerance of taxa

\section{Genus Level of Most Probable Stream Status (with Chironomidae Family) - GLIMPSS (CF):}

No. Intolerant taxa $(<3)$

No. of scraper genera

$\%$ Dominant 5 genera

No. of clinger taxa

No. of total genera

No. E genera

$\%$ Chironomidae

$\%$ EPT (minus

Cheumatopsyche)
Number of genera with a tolerance value $<3$

Number of genera with scraper feeing mechanism

Relative abundance of individuals in the top 5 dominant genera

Number of genera with clinger habit

Total number of genera present

Total number of mayfly genera

Relative abundance of individuals in the family of non-biting midges

Relative abundance of individuals in the orders E, P, T (minus Cheumatopsyche)

Average abundance-weighted tolerance of genera

\section{Statistical Analysis}

To test hypotheses 1-3, simple linear regressions were used to test the effect of each environmental variable on each response variable (WVSCI, GLIMPSS (CF), Family and Genus $\mathrm{BI}$, scrapers, collector-gatherers, collector-filterers, clingers, and burrowers) in each year. All response variables were normally distributed except for Genus $\mathrm{BI}$; this variable was transformed (squared) to correct for left-skewedness. Repeated measures analysis of variances (ANOVA) was used to test the effect of each environmental variable on response variables across all four years. In addition, multiple regression with backwards elimination across all four years was conducted to determine which set of environmental variables contributed the most to predicting the response variables. Results of the multiple regressions should be interpreted with caution because the data may not meet the assumption of independence (i.e., the influence of $\mathrm{pH}$ upstream can have an effect on $\mathrm{pH}$ downstream). However, despite their physical connectedness, sites along the main stem of WR may be independent as supported by the 
unique macroinvertebrate community composition at each sample location (Figure A2). Also, the results of this study may not apply outside West Run watershed, as the study was not replicated in other watersheds. All statistical analyses were performed in SAS, JMP, and CANOCO (SAS®, Version 9.4, SAS Institute Inc., Cary, NC, USA, Copyright @ 2002-2010; JMP ®, Version Pro 14, SAS Institute Inc., Cary, NC, USA, Copyright (C 2015; CANOCO, Version 5.1, Biometris, Wageningen, Netherlands, Copyright (C) 2018), and data visualization was performed in JMP and R (Rstudio Team 2020).

When conducting many simultaneous analyses (i.e., 92 simple regressions per response variable since there were 23 environmental variables and 4 years; or 23 repeated measures ANOVAs per response variable), the probability of detecting false significant predictors (type I error) is increased. To control for this increased likelihood of type I error, the Benjamini-Hochberg procedure was applied, with setting the false discovery rate to 0.25 (Benjamini and Hochberg 1995). P-values from the simple regressions and ANOVAs were sorted and ranked from smallest to largest. The ranked p-values from the analyses were compared to the Benjamini-Hochberg critical value:

$$
=\left(\frac{i}{m}\right) Q
$$

where $i$ is the individual rank of the p-values, $m$ is the total number of tests, and $Q$ is the false discovery rate. To be considered significant, the $p$-value would have to be smaller than the critical value for that given rank. For example, the simple regressions had a total of 92 tests (23 environmental variables x 4 years) for each response variable. The p-value at rank 1 would have to be smaller than $1 / 92^{*} 0.25=0.0027$ to be significant. If a $p$-value was found significant, all previous (i.e., lower ranked) p-values were also considered significant. Benjamini-Hochberg adjusted significant values will be used to interpret the results since the potential for error is minimized.

Multivariate analysis was performed in order to visualize the relationships between community composition, sites, and environmental variables. Compositional species data is analyzed via unimodal methods. This analysis is based on untransformed percentage data and is appropriate for datasets containing many zeros (ter Braak and Smilauer 2018). An unconstrained ordination (indirect gradient analysis; i.e., based solely on species data) was conducted first to examine the full variability in the species composition. Subsequently a constrained ordination (direct gradient analysis; including species and environmental data) was conducted. In a constrained ordination, only the species composition variability is shown that can be explained by environmental variables. Thus, a Detrended Correspondence Analysis (DCA) and Canonical Correspondence analysis (CCA) were conducted, respectively. In the 
CCA, environmental variables that were highly correlated (Variance Inflation Factor $>20$ ) were removed from analysis and a forward selection was performed to select environmental variables with $P \leq 0.05$. To minimize noise, a reduced, family-level dataset consisting of 30 families that made up the majority of the community in West Run (Figure 3) was used. Specifically, for each family the relative abundances in the different sites were averaged across sites for each year; subsequently family relative abundances were averaged across the four years and then ranked from highest to lowest. The families with the highest relative abundances that summed to $99 \%$ were included. To reduce the potential error of skewing the community composition, 4 of the 36 samples that had fewer than 25 individuals were omitted (Table A2).

\section{Results}

A total of 37 insect families and 10 non-insect groups were identified in West Run creek. From the 37 insect families, 42 genera were identified (Table A3; Figure A1). Hydropsychidae (net-spinning caddisflies) and Chironomidae (nonbiting midges) were the most abundant families (Figure 3, Figure A2) while Hydropsyche and Cheumatopsyche were the most abundant genera identified. Of the feeding groups, collector-filterers and collector-gatherers were the most abundant (Figure 4) while burrowers and clingers were the most abundant habits (Figure 5) at study sites. 


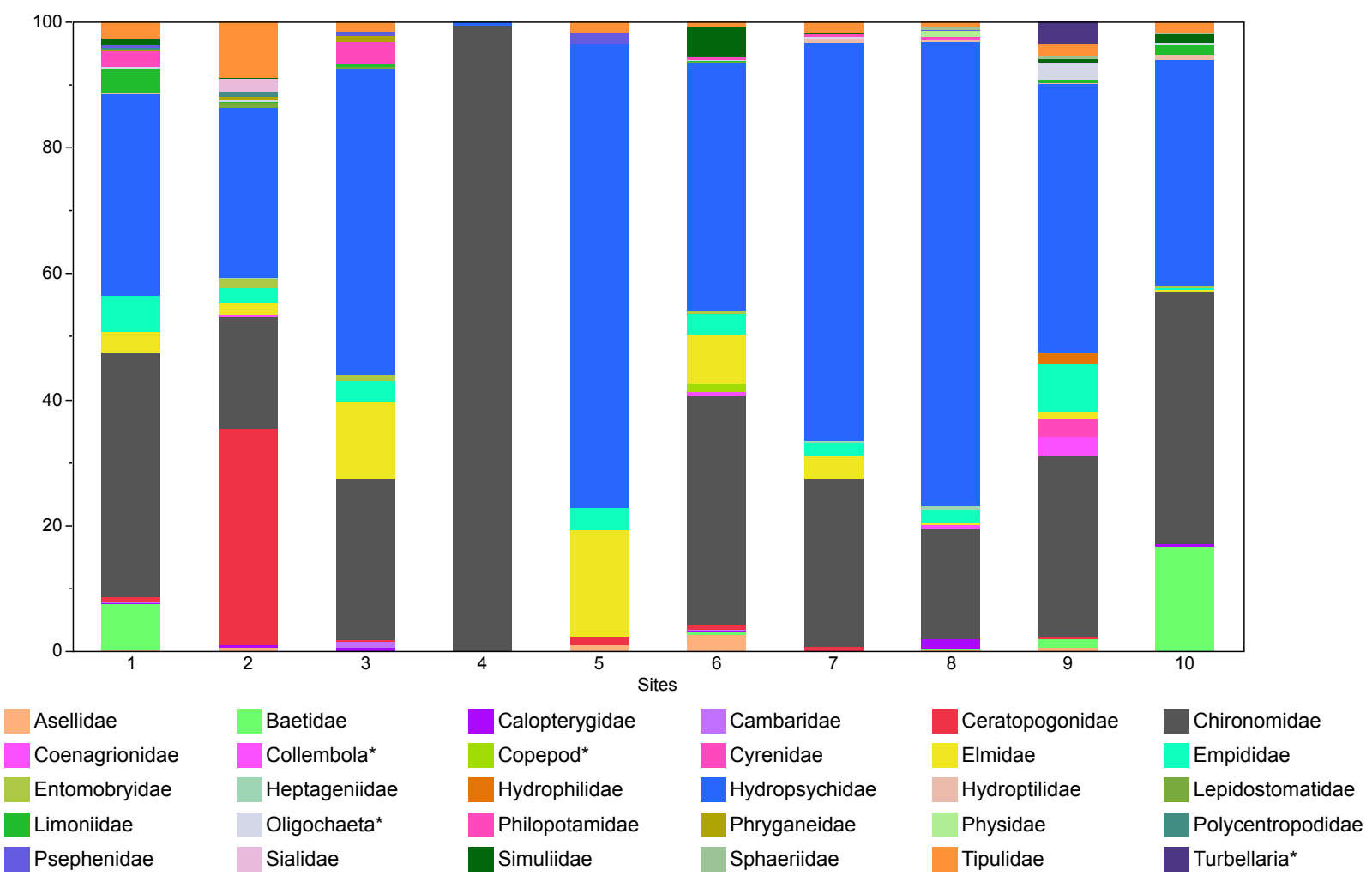

Figure 3. Macroinvertebrate community composition of WRW. Data shown were derived from the reduced dataset (averaged across years and rescaled to 100) containing the top 30 families that make up $99 \%$ of community composition. Sites $4(2016,2019)$ and Site $5(2016,2017)$ were removed due to very low abundance of organisms in the sample. Refer to Figure A2 in the appendix for community composition of full dataset.



Figure 4. Functional feeding group composition at each site in West Run Watershed. Data were derived from the full dataset (42 genera) based on genus traits. Data were averaged across the four years. Collector-filterers and collector-gatherers were the most abundant feeding group throughout the watershed. 


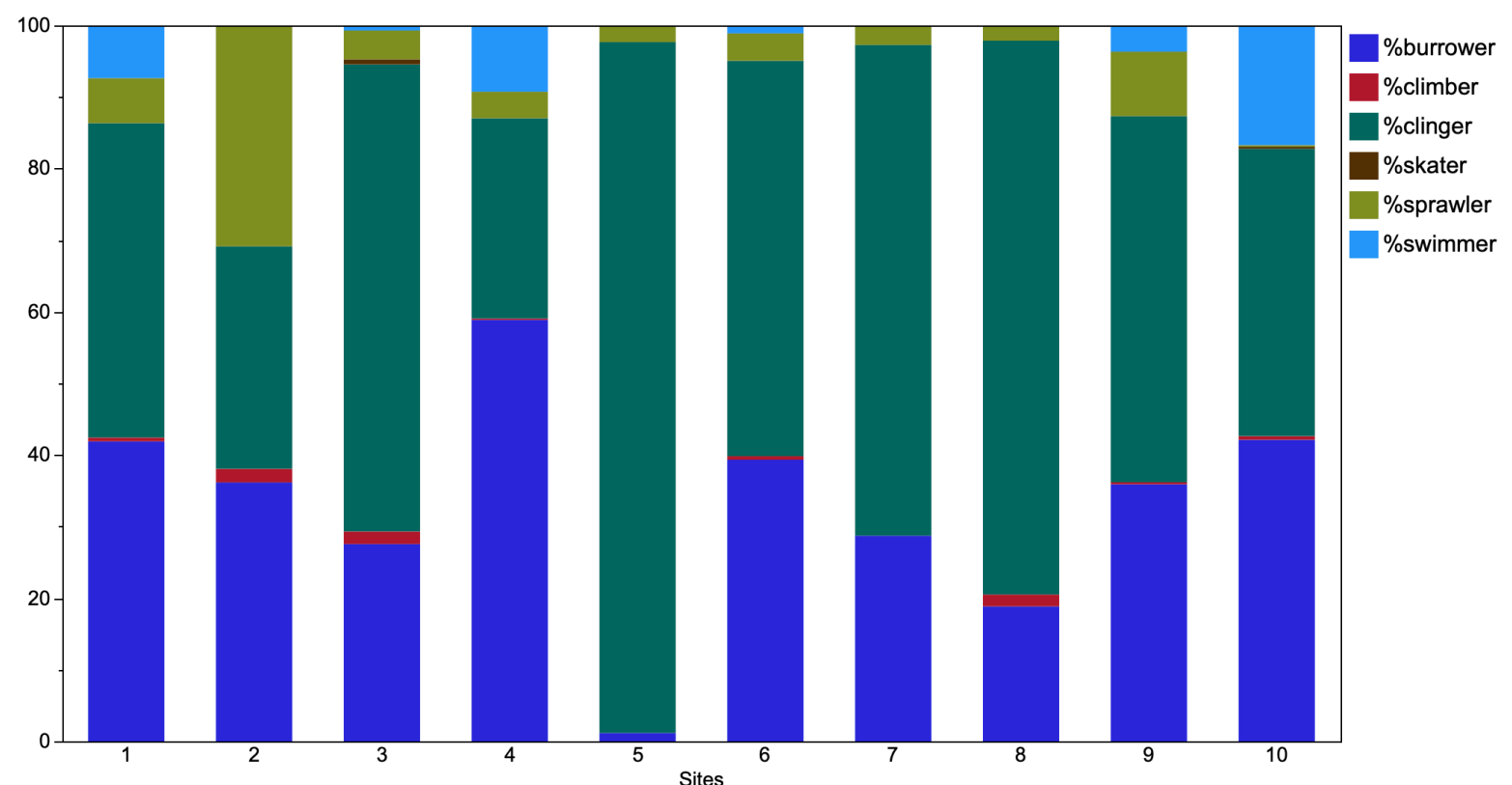

Figure 5. Habit composition at each site in West Run Watershed. Data were derived from the full dataset (42 genera) based on genus traits. Data were averaged across the four years. Clingers and burrowers were the most abundant habits throughout the watershed.

\section{Macroinvertebrate community patterns}

Unconstrained ordination illustrated the relationships between the relative abundances of macroinvertebrate families and sites. The DCA (with the first two axis explaining $37 \%$ of the variation) showed a co-occurrence of Polycentropodidae, Tipulidae, Sialidae, Phryganidae, Lepidostomadidae, Ceratopogonidae, Entomobryidae, and Asellidae with their highest relative abundance at Site $2(2016,2018,2019)$ (Figure 6A, C). Sites 4 (2017) and $9(2016,2019)$ had distinct communities (Figure 6B) with the highest predicted frequency of Chironomidae and Limoniidae (Figure 6C). While sites generally had similar community composition in different years, this was not always the case (e.g., Site 3, 9, 10) (Figure 6B).

In the CCA (including environmental variables), the first two axes cumulatively explained $26 \%$ of the variation in the response data (family relative abundances), and $65 \%$ of the variation in the fitted response data (i.e., the variation in macroinvertebrate data that can be explained by the environmental variables). Of the 23 environmental variables used in data analyses, only six were used in the CCA. Those environmental variables that were autocorrelated (VIF > 20) were removed and significant $(P \leq 0.05)$ predictors were identified by forward selection. For example, since TDS and Conductivity had a high degree of similarity, only one (TDS) was selected to be in the model. However, during the forward selection, TDS did not make it into the final model since it was not significant $(P>0.05)$. The six environmental variables that were selected to be 
in the final model were sub-watershed scale Agriculture and Forest land use, Forest buffer, Sediment Deposition score, NPDES outlet density, and NPDES mining outlet density. CCA indicated that sites with the highest percentage of sub-watershed forest cover had the lowest density of NPDES outlets; an example of such a combination was Site 2 (Figure 7B). Sites that had poor sediment deposition habitat scores (i.e., high levels of sediment deposition present) also had a low percentage of forested riparian buffer and the highest percentage of agricultural land at the sub-watershed scale (e.g., Sites 5, 7 ,8) (Figure 7B). Site 9, a sub-watershed with only $3 \%$ forest cover, was separated from the other sites along the third ordination axis (Figure 7B, inset). Tolerant taxa (Oligochaeta, Turbellaria) were relatively more abundant in sites with high NPDES and NPDES mining outlet density (Figure 7A). Heptageniidae, Physidae, and Psephenidae (all scrapers) were relatively more abundant in sites with higher agricultural land use in the sub-watershed.

Most sites' Family BI (nine of ten) and Genus BI (eight of ten) reflected fair water quality (5.01- 5.75), with tributary Sites 4 and 6 being the exceptions with fairly poor water quality (5.766.50). Site 3 (mainstem) had the best average WVSCI (55), GLIMPSS (CF) (35.69) and Family $\mathrm{BI}(5.10)$ scores, and the highest percent of scrapers (12.3\%). Site 4 had the lowest average WVSCI (30.99) and GLIMPSS (CF) (9.60) scores, the highest percent of burrowers (58.87\%) and collector-gatherers (67.56\%), and the lowest percent of clingers (28\%) and collector-filterers (24.55\%) (Table 4; Figure 5; Figure 4). Notably, Site 4 and 5 had extremely low macroinvertebrate abundances (Table A2). Scores of all response variables for each sample can be found in Table A4.

Most sites in WRW had marginal physical habitat scores (scoring 6-10 on a scale of 020) (Table 5). When comparing average total habitat scores (scale 0-200), sites 5, 4, and 7 , respectively, had the lowest total habitat scores $(82,87,89)$ of all sites, while sites 10,8 , and 1 had the highest total habitat scores $(128,105,105)$ of all sites. On average, riparian vegetative zone width (3.3), vegetative protection (5.8), and bank stability (6.0) were the most degraded habitat parameters of the habitat assessment in the watershed (Table 5). 

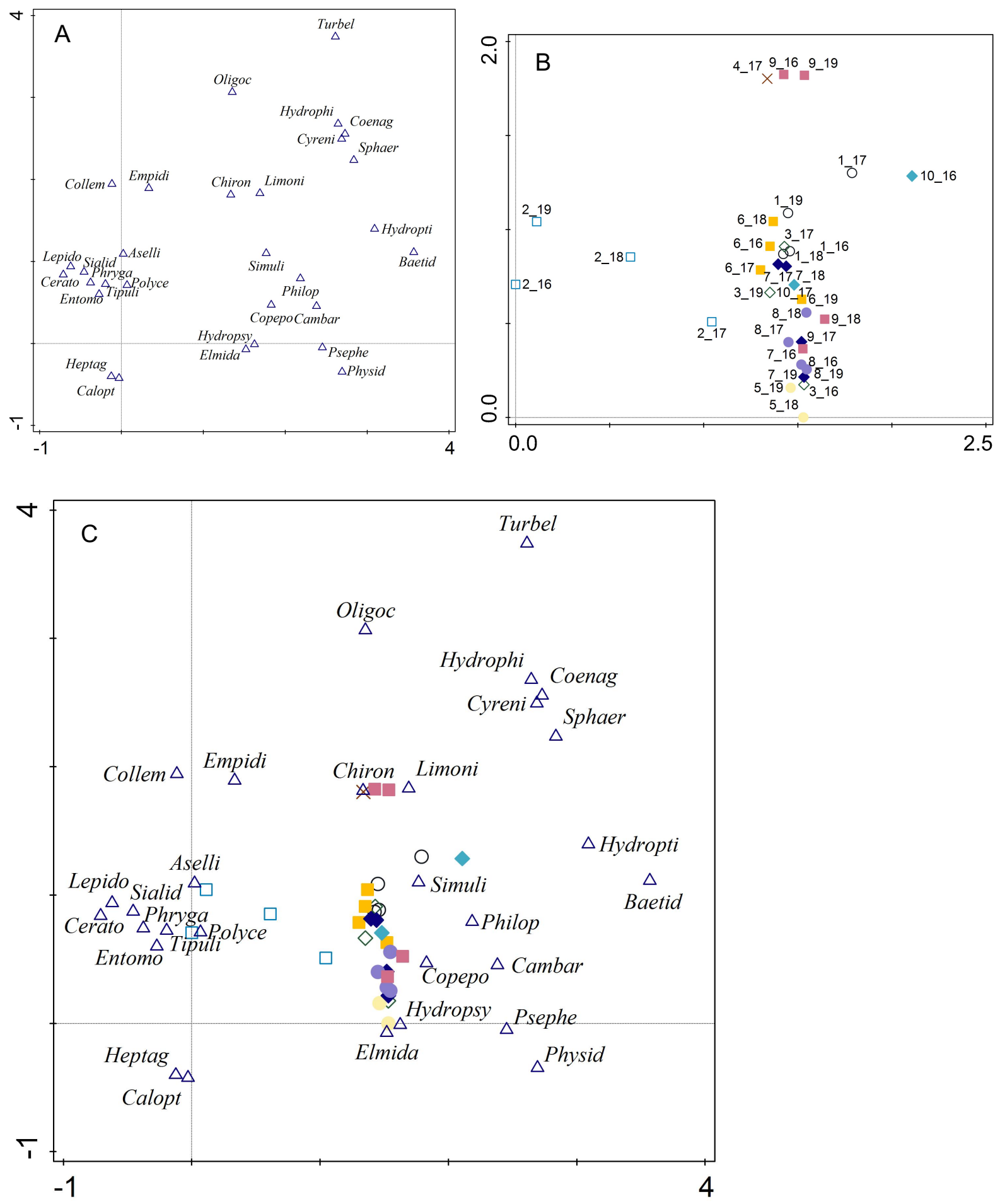

Figure 6. Detrended Correspondence Analysis (DCA) ordination diagram axes 1 and 2 displaying Species (A), Samples (sites in each year) (B), and Species and Sites (C) based on inter-site distances (Hill's scaling). Species symbols in proximity indicate that these species occur together in many samples. The distance between the Sample symbols approximates the dissimilarity of their species composition. Species symbols are near symbold for Samples in which they occur with the highest relative abundance, and similarily, the Sample symbols are near the symbols of Species that tend to occur in those Samples. Samples of the same site (1-10) have the same symbol shape and color for the different years (2016-19); Sample labels are omitted for space reasons in panel C. 



Figure 7. Canonical Correspondence Analysis (CCA) ordination diagrams (biplots) of environmental variables and macroinvertebrate families (A) and Samples (sites in different years) (B), respectively. Main plots show axes 1 and 2; the inset plot shows axes 1 and 3 . The arrows point toward the direction of the steepest increase of values of environmental variables; the coordinates of an arrow tip are correlations of the environmental variable with the two ordination axes (e.g., NPDES is highly correlated with axis 1, but there is almost no correlation with axis 2). Biplots with families (A) summarize the variation in macroinvertebrate composition explained by environmental variables. Species symbols in close proximity indicate that these species occur together in many samples. The approximate optimum of a family (i.e., highest relative abundance) along an environmental gradient is obtained by perpendicularly projecting the family symbol onto the environmental arrow. In (B), the distance between Sample symbols approximates the dissimilarity of their species composition; when projecting symbols orthogonally onto an environmental arrow, the value of the environmental variable for this Sample can be approximated. Inset biplot (axis 1 and 3) shows that Site 9 is distinct with very low Forest land use in the sub-watershed. 
Table 4. Summary of response variables averaged across the four years for each site. Values in parenthesis represent 1 SD.

\begin{tabular}{|c|c|c|c|c|c|c|c|c|c|c|}
\hline Resp & Site 1 & Site 2 & Site 3 & Site 4 & Site 5 & Site 6 & Site 7 & Site 8 & Site 9 & Site 10 \\
\hline WSCI & $50.45(8.96)$ & $47.11(4.34)$ & $54.92(7.15)$ & $30.99(15.40)$ & $43.10(11.34)$ & $46.32(6.49)$ & $43.94(11.64)$ & $5.40)$ & $48.80(7.22)$ & 5) \\
\hline GLII & $31.34(11.63)$ & $22.85(7.22)$ & $35.69(9.02)$ & $9.60(8.22)$ & $26.62(10.56)$ & $29.23(8.98)$ & $28.99(12.09)$ & $29.65(4.19)$ & $24.04(5.64)$ & 21.1 \\
\hline m: & $5.20(0.14)$ & $5.38(0.37)$ & $5.10(0$. & . & $5.20(0.54)$ & 5.51 & 5.23 & 5.23 & $5.61(0.49)$ & $5.23(0.01)$ \\
\hline Genu & 5.59 & 5.50( & 5.38 & $6.20(0.25)$ & 5.03 & 5.59( & 5.39 & 5.43 & $5.79(0.30)$ & 5.71 \\
\hline$\%$ Collector-filterer & $35.51(12.03)$ & $27.12(19.29)$ & $50.77(24.49)$ & $24.55(24.74)$ & $61.39(42$ & $44.10(12.82)$ & $63.79(14.96)$ & $73.80(8.46)$ & 46.76( & $37.19(2$ \\
\hline$\%$ Collector- $\mathrm{c}$ & $46.91(19.83)$ & $35.52(11.52)$ & $27.69(19.54)$ & $67.56(27.74)$ & 0.43( & $42.44(10.92)$ & $27.28(7.11)$ & $17.98(7.11)$ & $33.49(21.74)$ & 56.97 \\
\hline$\% \mathrm{~S}$ & $3.93(2.18)$ & $2.17(3.90)$ & $12.30(4.74)$ & $0.00(0.00)$ & $9.16(11.21)$ & $8.21(2.50)$ & $4.26(2.57)$ & $3.00(2.63)$ & $1.68(2.19)$ & $1.03(0.74)$ \\
\hline$\%$ Burrower & $41.90(11.33)$ & $36.17(25.72)$ & $27.56(17.02)$ & $58.87(35.06)$ & $0.88(1.75)$ & $39.33(12.25)$ & 28.72(16.89) & $18.85(8.29)$ & $35.90(24.04)$ & $42.12(8.14)$ \\
\hline$\%$ Clinger & $43.91(15.93)$ & 31.07 (20.71) & $65.24(20.01)$ & $27.97(25.14)$ & $72.37(48.50)$ & $55.23(10.52)$ & $68.55(17.45)$ & $77.36(8.15)$ & $51.15(32.18)$ & $40.13(29.67)$ \\
\hline
\end{tabular}

Table 5. Summary of environmental variables averaged across the four years for each site. Habitat variables were scored on a scale of 0 (poor) to 20 (optimal conditions). Values in parenthesis represent 1 SD.

\begin{tabular}{|c|c|c|c|c|c|c|c|c|c|c|}
\hline Environmental Variables & Site 1 & Site 2 & Site 3 & Site 4 & Site 5 & Site 6 & Site 7 & Site 8 & Site 9 & Site 10 \\
\hline Epifaunal substrate/ Available cover & $8.3(3.2)$ & $8.8(4.6)$ & $6.3(3.1)$ & $7.3(3.2)$ & $6.3(4.0)$ & $10.5(5.3)$ & $6.5(3.1)$ & $14.5(3.8)$ & $9.3(4.3)$ & $13.5(3.5)$ \\
\hline Embeddedness & $7.8(4.6)$ & $8.5(6.0)$ & $7.0(4.6)$ & $6.3(5.9)$ & $10.0(5.9)$ & $9.0(3.2)$ & $8.0(3.6)$ & $11.3(3.8)$ & $9.3(3.9)$ & $12.5(4.9)$ \\
\hline Velocity/Depth Regime & $14.5(3.1)$ & $10.8(3.5)$ & $12.7(4.2)$ & $14.0(2.6)$ & $14.8(1.3)$ & $12.3(5.2)$ & $14.3(4.2)$ & $13.8(3.9)$ & $11.3(3.9)$ & $18.5(0.7)$ \\
\hline Sediment Deposition & $13(1.8)$ & $11(2.7)$ & $8.7(3.8)$ & $10.7(5.5)$ & $7.5(4.7)$ & $11.3(5.4)$ & $7.3(5.1)$ & $11.0(3.9)$ & $9.8(4.5)$ & $12.5(4.9)$ \\
\hline Channel Flow Status & $16(1.6)$ & $13.8(6.0)$ & $16.3(2.5)$ & $16.7(1.5)$ & $15.0(4.1)$ & $16.0(3.6)$ & $13.5(3.1)$ & $12.5(4.1)$ & $14.3(4.1)$ & $15.0(2.8)$ \\
\hline Channel Alteration & $9.5(2.4)$ & $7.3(2.2)$ & $12.0(1.7)$ & $5.7(5.5)$ & $10.5(2.6)$ & $8.5(2.4)$ & $11.5(3.3)$ & $10.8(4.5)$ & $9.0(2.6)$ & $13.5(2.1)$ \\
\hline Frequency of riffles (or bends) & $16.8(1.0)$ & $14.3(3.3)$ & $12.0(5.6)$ & $16.3(0.6)$ & $9.8(5.2)$ & $13.3(4.2)$ & $13.8(4.8)$ & $15.3(3.2)$ & $12.8(3.5)$ & $18.0(1.4)$ \\
\hline Bank Stability & $7.5(1.8)$ & $8.5(0.7)$ & $5.7(2.1)$ & $6.0(2.0)$ & $3.9(2.1)$ & $5.8(1.6)$ & $3.1(2.0)$ & $6.1(3.3)$ & $6.6(2.3)$ & $8.3(2.5)$ \\
\hline Vegetative Protection & $6.8(1.5)$ & $6.6(1.5)$ & $7(0.0)$ & $3.2(1.5)$ & $2.6(1.5)$ & $6.9(2.1)$ & $5.5(1.1)$ & $6.4(2.7)$ & $6.4(0.8)$ & $8.5(0.7)$ \\
\hline Riparian Vegetative Zone Width & $4.5(2.2)$ & $4.6(2.9)$ & $2.5(0.5)$ & $0.8(0.6)$ & $1.8(2.5)$ & $1.3(0.5)$ & $5.4(0.9)$ & $3.4(1.5)$ & $2.4(0.5)$ & $8.0(0.7)$ \\
\hline Total habitat score & 104.5 & 94.0 & 90.2 & 87.0 & 82.0 & 94.6 & 88.8 & 104.9 & 90.9 & 128.3 \\
\hline NPDES & 3.09 & 0.0 & 2.57 & 4.58 & 2.97 & 1.35 & 2.27 & 2.17 & 0.63 & 2.15 \\
\hline NPDES mining & 0.0 & 0.0 & 0.0 & 0.35 & 0.09 & 0.54 & 0.18 & 0.15 & 0.0 & 0.12 \\
\hline Conductivity $(\mu \mathrm{S} / \mathrm{cm})$ & $\begin{array}{c}844.5 \\
(287.5)\end{array}$ & $\begin{array}{l}1217.3 \\
(255.6)\end{array}$ & $\begin{array}{c}957.0 \\
(242.6)\end{array}$ & $\begin{array}{l}1680.3 \\
(301.9)\end{array}$ & $\begin{array}{c}918.0 \\
(139.3)\end{array}$ & $\begin{array}{l}487.0 \\
(73.5)\end{array}$ & $\begin{array}{c}767.3 \\
(151.9)\end{array}$ & $\begin{array}{c}771.5 \\
(135.9)\end{array}$ & $\begin{array}{c}838.3 \\
(142.4)\end{array}$ & $\begin{array}{c}855.5 \\
(106.8)\end{array}$ \\
\hline TDS (g/L) & $0.5195(0.2)$ & $0.752(0.2)$ & $0.5857(0.2)$ & $1.0357(0.3)$ & $0.5698(0.1)$ & $0.2988(0.0)$ & $0.4693(0.1)$ & $0.5253(0.1)$ & $0.5123(0.1)$ & $0.5565(0.1)$ \\
\hline $\mathrm{pH}$ & $7.7(0.4)$ & $7.5(0.3)$ & $6.9(0.2)$ & $4.3(1.1)$ & $5.8(1.1)$ & $7.4(1.0)$ & $7.8(0.4)$ & $7.8(0.4)$ & $7.8(0.7)$ & $7.1(1.7)$ \\
\hline
\end{tabular}


Table 6. Statistically significant slopes $(P \leq 0.05)$ and $R^{2}$ values (in parentheses) from simple regressions of taxonomic, feeding mode, and habit metrics against environmental variables by year. Genus BI was squared (Genus $\mathrm{BI}^{2}$ ) to correct for skewedness. Environmental variables are separated into land use, habitat scores, and water chemistry by horizontal lines. The last column shows statistically significant slopes from repeated measures ANOVAs for all years combined. The asterisk $\left(^{*}\right)$ indicates that the environmental variable remained significant after the Benjamini-Hochberg adjustment for family-wise error rate, and slopes in brackets indicate a statistical trend $(P \leq 0.1)$ across all years. Highlighted slopes are opposite to expectations.

\begin{tabular}{|c|c|c|c|c|c|}
\hline & 2016 & 2017 & 2018 & 2019 & All Years \\
\hline \multicolumn{6}{|l|}{ WVSCI } \\
\hline Sediment Deposition & & & & & $-0.86^{*}$ \\
\hline Riparian Vegetative Zone Width & & & & $0.04(0.47)$ & \\
\hline Conductivity & & & & & $-0.01^{*}$ \\
\hline TDS (g/L) & & & & & $-18.86^{*}$ \\
\hline $\mathrm{pH}$ & & $7.83(0.74)^{*}$ & & & $3.92^{*}$ \\
\hline NPDES/ km2 & & $-8.32(0.69)^{*}$ & & & \\
\hline \multicolumn{6}{|l|}{ GLIMPSS (CF) } \\
\hline Embeddedness & & & $3.08(0.78)$ & & \\
\hline Bank Stability & & & $-3.81(0.64)$ & & \\
\hline Conductivity & & $-0.02(0.55)$ & & & $-0.02^{*}$ \\
\hline TDS (g/L) & & $-29.51(0.55)$ & & & $-23.88^{*}$ \\
\hline $\mathrm{pH}$ & & $5.44(0.52)$ & & & $3.35^{\star}$ \\
\hline NPDES/ km2 & & $-6.21(0.55)$ & $4.26(0.60)$ & & \\
\hline \multicolumn{6}{|l|}{ Family BI } \\
\hline$\%$ Developed Buffer & $0.01(0.41)$ & & & & \\
\hline Sediment Deposition & & & $0.05(0.61)$ & & \\
\hline Riparian Vegetative Zone Width & & $-0.09(0.41)$ & & & \\
\hline Conductivity & & & & $0.002(0.52)$ & {$[0.00044]$} \\
\hline TDS (g/L) & & & & $3.12(0.53)$ & {$[0.62]$} \\
\hline $\mathrm{pH}$ & & $-0.20(0.76)^{*}$ & & & -0.12 \\
\hline NPDES/ km2 & & $0.18(0.54)$ & & & \\
\hline \multicolumn{6}{|l|}{ Genus $\mathrm{BI}^{2}$} \\
\hline$\%$ Ag Buffer & & & & & -0.04 \\
\hline \%Developed Buffer & & & & & {$[0.04]$} \\
\hline Sediment Deposition & & & & & {$[0.34]$} \\
\hline Bank Stability & $1.62(0.64)^{*}$ & & & & [0.52] \\
\hline Frequency of riffles (or bends) & & & & & {$[0.32]$} \\
\hline Vegetative Protection & & & $1.12(0.62)$ & & \\
\hline Conductivity & & & & $0.01(0.46)$ & \\
\hline TDS (g/L) & & & & $27.14(0.47)$ & \\
\hline NPDES/ km2 & & $2.49(0.74)^{*}$ & & & \\
\hline
\end{tabular}


Table 6 continued.

\begin{tabular}{|c|c|c|c|c|c|}
\hline & 2016 & 2017 & 2018 & 2019 & All Years \\
\hline \multicolumn{6}{|l|}{ Burrowers } \\
\hline \%Developed Buffer & & & & $0.46(0.45)$ & \\
\hline Sediment Deposition & & $4.54(0.48)$ & & & 2.04 \\
\hline Frequency of riffles (or bends) & & & $-7.5(0.83)$ & & \\
\hline Conductivity & & $0.04(0.49)$ & & & {$[0.02]$} \\
\hline TDS (g/L) & & $61.45(0.49)$ & & & {$[27.90]$} \\
\hline $\mathrm{pH}$ & & $-15.30(0.62)$ & & & \\
\hline NPDES/ km2 & & $15.97(0.73)$ & & & \\
\hline \multicolumn{6}{|l|}{ Clingers } \\
\hline$\% A g$ & & & & & $2.14^{*}$ \\
\hline Embeddedness & & & $10.43(0.67)$ & & \\
\hline Sediment Deposition & & & & & $-2.54^{*}$ \\
\hline Bank Stability & $-7.77(0.65)^{\star}$ & & & & $-3.76^{*}$ \\
\hline Conductivity & & & & & $-0.03^{*}$ \\
\hline TDS (g/L) & & & & & $-44.56^{*}$ \\
\hline $\mathrm{pH}$ & & $15.84(0.61)^{\star}$ & & & \\
\hline NPDES/ km2 & & $-17.64(0.63)^{*}$ & & & \\
\hline \multicolumn{6}{|l|}{ Collector-gatherers } \\
\hline$\%$ Ag Buffer & & & $0.34(0.70)$ & & \\
\hline Sediment Deposition & & $5.48(0.55)$ & & & 1.98 \\
\hline Conductivity & & & & & {$[0.02]$} \\
\hline TDS (g/L) & & & & & 37.70 \\
\hline $\mathrm{pH}$ & & $-15.11(0.47)$ & $21.06(0.70)$ & & -7.65 \\
\hline NPDES/ km2 & & $18.94(0.79)$ & & & \\
\hline \multicolumn{6}{|l|}{ Collector-filterers } \\
\hline$\% A g$ & & & & & 2.85 \\
\hline \%Developed & & & $6.86(0.72)$ & & \\
\hline$\%$ Forest & & & & & {$[-1.47]$} \\
\hline Sediment Deposition & & $-4.85(0.56)$ & & & $-2.88^{*}$ \\
\hline Bank Stability & $-7.84(0.68)$ & & & & -3.96 \\
\hline Conductivity & & & & & {$[-0.02]$} \\
\hline $\mathrm{pH}$ & & $13.03(0.45)$ & & & \\
\hline NPDES/ km2 & & $-14.96(0.64)$ & & & \\
\hline \multicolumn{6}{|l|}{ Scrapers } \\
\hline \%Barren & $-0.87(0.46)$ & & & & \\
\hline \%Developed & & & & & {$[-0.70]$} \\
\hline \%Ag Buffer & & & $0.19(0.72)$ & & \\
\hline Frequency of riffles (or bends) & & & $-2.36(0.61)$ & & \\
\hline
\end{tabular}


Table 7. Slopes from the multiple regression backwards eliminations indicate which environmental variables are contributing $(P<0.1)$ to each response variable. GLIMPSS incorporates both taxonomic and trait-based metrics, thus does not fall into one category (i.e., taxonomic vs. trait-based).

Environmental variables that did not significantly contribute to the model $(-)$ had VIF $>10$. The first ten environmental variables are expressed as habitat scores, i.e., a high Embeddedness score, Sediment Deposition score and Channel Alteration score indicate quality habitat. $R^{2}$ values listed in the last row show the total variation explained by the variables. The cells highlighted in grey represent relationships opposite of expectations.

\begin{tabular}{|c|c|c|c|c|c|c|c|c|c|}
\hline \multirow[b]{2}{*}{ Environmental variables } & \multicolumn{3}{|c|}{ Taxonomic Metrics } & \multirow[b]{2}{*}{ GLIMPSS } & \multicolumn{5}{|c|}{ Trait-based Metrics } \\
\hline & $\begin{array}{c}\text { Family } \\
\text { BI }\end{array}$ & $\begin{array}{c}\text { Genus } \\
\mathrm{BI}^{2}\end{array}$ & WVSCI & & Burrowers & Clingers & Scrapers & $\begin{array}{l}\text { Collector- } \\
\text { gatherers }\end{array}$ & $\begin{array}{l}\text { Collector- } \\
\text { filterers }\end{array}$ \\
\hline Epifaunal Substrate & - & - & -1.04 & - & - & - & - & - & - \\
\hline Embeddedness & - & -0.34 & 0.82 & - & - & 2.11 & - & -2.07 & - \\
\hline Velocity / Depth Regime & - & -0.49 & - & - & - & - & - & - & - \\
\hline Sediment Deposition & 0.03 & 0.30 & -1.53 & -0.76 & 3.51 & -3.21 & - & 2.80 & -3.21 \\
\hline Channel Flow Status & - & - & 1.10 & 0.74 & -3.56 & - & - & - & - \\
\hline Channel Alteration & - & - & - & -0.75 & - & - & - & 1.74 & - \\
\hline Frequency of Riffles & - & 0.65 & - & - & - & - & - & - & - \\
\hline Bank Stability & - & - & 1.86 & - & -2.65 & - & 0.95 & -4.49 & - \\
\hline Vegetative Protection & - & - & - & - & 5.00 & - & - & 3.71 & - \\
\hline Riparian Zone Width & - & - & - & - & - & - & - & - & - \\
\hline $\mathrm{pH}$ & -0.17 & -1.60 & 3.75 & - & -17.68 & 12.62 & - & -16.74 & 13.76 \\
\hline TDS (g/L) & - & - & -21.02 & -35.04 & - & - & - & - & - \\
\hline Conductivity & - & - & - & - & - & - & -0.01 & - & - \\
\hline NPDES Mining & 0.74 & - & - & -22.79 & - & - & -19.11 & 64.56 & - \\
\hline NPDES & - & - & - & - & - & 9.46 & 2.36 & -8.09 & 9.47 \\
\hline Forested & - & - & - & - & - & -1.61 & -0.72 & 3.36 & - \\
\hline Agriculture & - & - & - & - & - & - & - & - & - \\
\hline Developed & - & - & - & - & - & -3.55 & -2.31 & 7.50 & - \\
\hline Barren & - & - & - & - & -4.07 & - & - & - & 4.54 \\
\hline Forested Buffer & - & - & -0.16 & - & 0.29 & - & - & - & -0.55 \\
\hline Agriculture Buffer & - & - & -0.21 & - & - & - & - & - & - \\
\hline Developed Buffer & - & - & - & - & - & - & - & - & - \\
\hline Barren Buffer & - & - & - & - & - & - & - & - & - \\
\hline $\mathrm{R}^{2}$ & 0.56 & 0.50 & 0.72 & 0.56 & 0.80 & 0.59 & 0.47 & 0.75 & 0.69 \\
\hline
\end{tabular}

The results of the simple regressions (for each year) indicated that bank stability, $\mathrm{pH}$, and NPDES density were significant predictors of macroinvertebrate composition after the Benjamini-Hochberg adjustment was applied (Table 6). Repeated measures ANOVA indicated that sediment deposition, TDS, conductivity, $\mathrm{pH}$, bank stability, and \% agricultural land use were significant predictors of macroinvertebrate composition after the Benjamini-Hochberg adjustment was applied (Table 6, last column). The multiple regressions with backwards elimination revealed that $47 \%-80 \%$ of variation in the datasets could be explained by these 
environmental variables (Table 7). Relationships between taxonomic and trait-based metrics and each of the 23 predictor variables are visualized in Figures A3-A11.

\section{Effects of land use on macroinvertebrate metrics}

Of the all the land use variables (agriculture, barren, developed, forest), only agriculture was found to be significant $(P<0.05)$ in predicting percent clingers across all four years. There was a positive relationship (slope $=2.1$ ) between sub-watershed agricultural land use and percent clingers (Table 6). In the multiple regression analyses, there were 10 (of 40, 25\%) instances of significant correlations between trait-based metrics and land use variables. In comparison, there were only 2 (of $24,8.3 \%$ ) significant correlations between taxonomic metrics and land use variables (Table 7). Thus, trait-based metrics were more indicative of land use impacts compared to taxonomic metrics.

\section{Effects of water chemistry on macroinvertebrate metrics}

Water chemistry predictor variables were found to be the most influential in explaining variability of response variables. Across all simple regressions, six of the eight BenjaminiHochberg adjusted significant predictor variables were streamwater chemistry variables, and eight of the thirteen Benjamini-Hochberg adjusted significant predictor variables of the repeated measure ANOVAs were streamwater chemistry variables (Table 6). Of the 23 environmental variables analyzed in the simple regressions, $\mathrm{pH}$ and NPDES density were significant in three occurrences, respectively (pH - 2017: Family BI, WVSCI, \% clingers) (NPDES - 2017: Genus BI, WVSCI, \% clingers). In 2017, NPDES density explained more than half of the variation in WVSCI $\left(R^{2}=69 \%\right)$, Genus BI $\left(R^{2}=74 \%\right)$, and clingers $\left(R^{2}=63 \%\right)$ between sites. As NPDES density increased, WVSCI, Genus BI, and \% clingers reflected greater stream impairment. Also in 2017, $\mathrm{pH}$ was significant in predicting WVSCI $\left(\mathrm{R}^{2}=74 \%\right)$, Family $\mathrm{BI}\left(\mathrm{R}^{2}=76 \%\right)$, and clingers $\left(\mathrm{R}^{2}=61 \%\right)$. These response variables reflected improved stream health as $\mathrm{pH}$ increased toward a more neutral $\mathrm{pH}$. In other individual years, water chemistry variables were not significant predictors of macroinvertebrate composition. However, across all years, $\mathrm{pH}$ was positively correlated with WVSCI and GLIMPSS. TDS and conductivity had a negative relationship with WVSCI, GLIMPSS, and clingers, respectively. 


\section{Effects of physical habitat parameters on macroinvertebrate metrics}

In the simple regressions, bank stability was significant in two occurrences (2016: Genus $\mathrm{BI}, \%$ clingers). Bank stability had a significant relationship with percent clingers (slope $=-7.8$ ) and Genus BI (slope = 1.6) (i.e., higher banks stability was associated with higher tolerance) in 2016. Across all years, sediment deposition and bank stability were the only significant predictors. Sediment deposition score (i.e., higher score means lower deposition) was negatively correlated with WVSCI (slope= -0.9), clingers (slope= -2.5), and collector-filterers (slope $=-2.9$ ), i.e., higher sediment deposition (lower score) was associated with better stream condition and higher proportion of clingers and collector-filterers. Additionally, bank stability was negatively correlated with clingers (slope $=-3.8$ ).

\section{Discussion}

Results of data analyses identified several factors that influenced the community composition of macroinvertebrates throughout an Appalachian mixed-land-use watershed. Most of the studied sites had fair water quality based on the range of $\mathrm{BI}$ (5.03-6.2) present in WR. The total scores of the habitat assessment indicated that most sites have marginal physical habitat quality, but the most significant differences of macroinvertebrate composition between sites were in response to streamwater quality variables (6 of 8 in regressions, 8 of 13 in ANOVAs).

Site differences in a mixed-land-use watershed

Although there has been much urbanization in WRW, forest cover is still the dominant land cover. Four of the ten sub-watersheds in this study were $57-64 \%$ forested, with most other sites ranging from $43-50 \%$ forested. Site 9 was the only exception with $92 \%$ developed/barren land use and only 3\% forested land cover. Surprisingly, despite differences in land use, there were no major shifts in macroinvertebrate composition or habitat parameters recorded at Site 9 (Table 4; Table 5) relative to the other sites. Contrary to expectations, Site 9 generally had similar macroinvertebrate community composition to most other sites. For example, the average WVSCI score at the most developed Site 9 (49) was similar to that of the three most forested sites (Sites 1-3, 47-55) (Table 4). This could be due to all sites being at or having greater than 8-15\% impervious cover (proxy for developed area), a threshold beyond which macroinvertebrate index scores decline (Riley et al. 2007; Roy et al. 2003). 
Instead, the most impaired site appeared to be Site 4, representing a tributary subwatershed with fairly average land use characteristics (50\% forested, $22 \%$ agricultural, $16 \%$ developed, and 12\% barren land use) for WRW. Macroinvertebrate natural abundance at Site 4 was low, and of the taxonomic metrics, when averaged across the four years, Site 4 generally had the lowest GLIMPSS (CF) and WVSCI scores, and highest Family and Genus BI scores of all sites. Additionally, Site 4 had the lowest proportion of collector-filterers and clingers, and the highest proportion of collector-gatherers and burrowers, which follows the expected responses of increased disturbance within a watershed. Ordination showed that Site 4 had a high proportion of more tolerant taxa (Chironomidae) (Figure 6C). The underlying impairment is likely due to several environmental variables. Site 4 had the highest density of NPDES outlets, conductivity, and TDS, while also having the lowest habitat scores for average embeddedness, channel alteration, and riparian vegetative zone width and the lowest average $\mathrm{pH}$ (4.3). The CCA ordination diagram also showed that Site 4 had high scores on NPDES and NPDES mining. In contrast, Site 4 had a high sediment deposition score, and forest buffer presence, indicating quality habitat (Figure 7B). While the unique macroinvertebrate composition and environmental conditions of Site 4 could not be reconciled with current land use, past mining activity likely can. This area of WRW was heavily mined (surface and underground) from 19301950 (WVWRI 2008). In 2008, the AMD flowing into the tributary represented by Site 4 had an average $\mathrm{pH}$ of 2.85 (WVWRI 2008), and the legacy effects are still observed today in the form of elevated Al, Fe, low pH, etc. (Kellner et al. 2018; Petersen and Hubbart 2020). When the effects of mining and residential development are combined, macroinvertebrate composition reflects even more degraded in-stream conditions compared to just mining or residential development effects alone (Merriam et al. 2011). Effects of mining generally result in changes in water quality (i.e., conductivity, dissolved constituents) (Pond et al. 2008), while the effects of development tend to influence physical habitat quality and complexity (Merriam et al. 2011). The CCA indicated that many sites are some combination of stressors that represent various land uses, but few have a dominant stressor (Figure 7). Although sites throughout this watershed are influenced by multiple stressors, our findings suggest that macroinvertebrate composition in WR are influenced most by in-stream water quality parameters associated with mining and urbanization. 


\section{Macroinvertebrate indices and environmental factors}

Across all four years, WVSCI and GLIMPSS (CF) indices indicated more impairment with increasing TDS and conductivity. For every $1 \mathrm{~g} / \mathrm{L}$ increase in TDS, WVSCI and GLIMPSS (CF) scores decreased by 19 and 24 units, respectively, and for every $1000 \mu S / c m$ increase in conductivity, WVSCI and GLIMPSS (CF) scores decreased by 10 and 20, respectively. Site 4 had the highest average conductivity $(1680.3 \mu \mathrm{S} / \mathrm{cm})$ and TDS $(1.0 \mathrm{~g} / \mathrm{L})$ followed by Site 2 (1217.3 $\mu \mathrm{S} / \mathrm{cm} ; 0.8 \mathrm{~g} / \mathrm{L}$ ), which was expected due to legacy effects of mining activities (WVWRI 2008). Site 4 and the immediate downstream mainstem site (Site 5), had low macroinvertebrate abundances consistent with previous findings of elevated conductivity and TDS causing biological impairment (Merriam et al. 2011; Olson \& Hawkins 2017; Roy et al. 2003; Vander Laan et al. 2013). Most sites throughout the watershed had high average conductivity (> 700 $\mu S / \mathrm{cm}$ ) which is a chronic symptom of urbanization (Walters et al. 2009) but could also be due to headwater AMD (Petersen and Hubbart 2020). The exception to this high average conductivity was Site $6(487 \mu \mathrm{S} / \mathrm{cm})$, a tributary sample location that had the lowest percent of developed land use relative to all other sites. Impairment was still detected at Site 6, which is consistent with previous findings that biological impairment can be detected in reaches with conductivity as low as $250 \mu \mathrm{S} / \mathrm{cm}$ (Merriam et al. 2011).

The only environmental variable that, across all four years, was positively correlated with WVSCI and GLIMPSS scores was pH. In 2018, Kellner et al. found that average $\mathrm{pH}$ ranged from 5.4 to 6.9 between WR mainstem sites $1200 \mathrm{~m}$ apart and average $\mathrm{pH}$ of tributary sites between those mainstem sites ranged from 6.7-8.2. In the current study, average $\mathrm{pH}$ of mainstem sites ranged from 5.8 to 7.8 and average $\mathrm{pH}$ of tributary sites ranged from 4.3-7.8. Sub-watersheds that have similar physical attributes within close proximity (Sites 3 and 4 or Sites 5 and 6) showed a large difference in $\mathrm{pH}$ (6.9-4.3 and 5.8-7.4, respectively) (Table 5), which indicates the potential of tributaries influencing the water chemistry of receiving waters.

This study showed that the density of point source outlets (NPDES) are inversely related to catchment-scale forest cover, i.e., as the amount of direct piped drainage per catchment increases, the percentage of forest cover decreases (Figure 7B). The CCA ordination diagram revealed that non-mining NPDES had a greater effect on macroinvertebrate composition compared to mining-related NPDES (Figure 7A), likely due to the large amount of non-mining NPDES outlets (57) compare to mining-related NPDES outlets (3) in the entire WR watershed. Frequent taxa at sites affected by NPDES are more tolerant taxa (e.g., Oligochaeta: TV 9) compared to frequent, sensitive taxa at sites with a high percentage of sub-watershed forest 
cover (e.g., Lepidostomatidae: TV 1). In WRW, many of the non-mining related NPDES permits are for industrial storm water and general sewage. Impacts of storm water on stream condition are often associated with increased urbanization and impervious surfaces (Walsh et al. 2005); thus, our findings are consistent with previous studies that have observed a shift toward tolerant taxa in areas that are influenced by urbanization (Nichols et al. 2016; Roy et al. 2003; Walsh et al. 2005).

Macroinvertebrate functional traits in response to environmental factors

Across all four years, the proportion of clingers in the community responded to the greatest number of environmental predictors compared to all other trait-based response variables (Table 6). Clingers increased as the percent agricultural land use at the subwatershed scale increased. Clingers are expected to decline under intensive land use alteration (Pond et al. 2011), because the substrates they characteristically "cling" to (surfaces of rocks, woody debris, mosses) get filled in by sediment often associated with agricultural land use, making their habitat unsuitable (Rabení et al. 2005). However, there have been some cases where slight increases in agricultural land use ( $<30 \%$ of catchment area) can actually enhance macroinvertebrates' food source, therefore benefiting the aquatic community (Riley et al. 2007). In the current study, improved food availability may have outweighed negative effects of sedimentation on clinger habitat. All sites in WRW had less than $30 \%$ of agriculture land use area per sub-watershed, which may explain the positive response of clingers to increases in agricultural land use (2\% increase in the proportion of clingers in the community for each $1 \%$ increase in agricultural land use within a range of $5-26 \%$ agricultural land use in this study). Alternatively, a larger proportion of agricultural land use may indicate a lower proportion of potentially more detrimental, developed land use. Based on the correlation matrix of the multivariate analysis, agricultural land use was negatively correlated with developed land use ($0.75)$, barren land cover $(-0.76)$, and developed riparian buffer $(-0.81)$. Further analyses are required to determine if there is a direct causative relationship between agricultural land use and response variables.

Interestingly, our results showed that clingers, collector-filterers, WVSCI, and GLIMPSS (CF) scores declined as some habitat variables (sediment deposition, bank stability) improved. Previous studies found that these response variables generally increase under improved water quality and habitat (Gerritsen et al. 2000; Pond et al. 2011; Walters et al. 2009; Fu et al. 2016). Therefore, the correlations of improved macroinvertebrate scores with higher sediment 
deposition or lower bank stability likely does not imply direct causation. It is possible that macroinvertebrate communities in WR declined in response to increased contaminants related to urbanization or legacy pollutants, even in areas with improved physical habitat. For example, even if an urban stream has favorable physical habitat (e.g., low sedimentation), conductivity may be causing macroinvertebrate indices to decline. In West Run specifically, there have been observed differences in $\mathrm{Cl}, \mathrm{Ca}, \mathrm{Mg}$, and $\mathrm{Na}$ between sites that are attributed to developed/urban land cover (Kellner et al. 2018; Petersen and Hubbart 2020). Previous studies detected negative trait-based and taxonomic-based responses to chloride concentrations, which can be problematic in urbanizing watersheds (Bazinet et al. 2010; Nichols et al. 2016). Additionally, Walsh et al. (2005) proposed that as the piped drainage network of a catchment increases, the relative influence of riparian zone on stream condition decreases. This means that as more point sources enter the stream, the benefits of riparian area can be outweighed by in-stream water quality.

\section{Taxonomic vs. Trait-based metrics}

A question that has been persistent throughout the literature regarding land use effects on macroinvertebrates, is whether traditional taxonomic metrics or trait-based metrics are more useful in assessing stream condition. Results of a study similar to this one indicated that traitbased metrics discriminated more between agricultural and urbanized sites (Nichols et al. 2016), but another study found that taxonomic-based metrics performed best in analysis (Bazinet et al. 2010). In this study, repeated-measures ANOVA (across all years) revealed that only WVSCI was sensitive to four environmental predictors out of all the taxonomic-based metrics (WVSCI, Family BI, and Genus BI). GLIMPSS (CF) was left out of this comparison because it is a composite index that incorporates both taxonomic and trait-based metrics. While WVSCI responded to four environmental predictors, trait-based metrics, clingers and collectorfilterers responded to five and only one environmental predictors, respectively. Family and genus $\mathrm{BI}$, scrapers, burrowers, and collector-gatherers failed to detect any significant differences between sites after the p-values were adjusted via the Benjamini-Hochberg method.

When considering the multiple regression outcomes, on average, taxonomic-based metrics were sensitive to on average 5.7 of 23 environmental variables (25\%), and trait-based metrics were sensitive to on average 6.8 of $23(30 \%)$. Trait-based metrics were also more sensitive to catchment-scale and riparian buffer land use variables than taxonomic metrics, responding to $25 \%$ compared to $8 \%$ of the eight land use variables, respectively. Our results demonstrate a stronger relationship of trait-based responses to land use characteristics relative 
to taxonomic metrics, which is consistent with the findings of Nichols et al. (2016). Since macroinvertebrate functional groups strongly rely on physical habitat characteristics (e.g., streambed substrate, organic matter input), trait-based metrics often reflect the condition of the physical environment, which could be linked to the land use/cover in the surrounding area (Poff et al. 2006). Perhaps composite indices (e.g., GLIMPSS) are a more useful approach in assessing general stream condition because it averages several taxonomic and trait-based metrics, whereas the use of single (i.e., not composite) trait-based metrics or taxonomic metrics may be more useful in identifying causes of impairment (i.e., habitat quality and water chemistry).

\section{Limitations}

Results from this study represent many effects of land use on aquatic macroinvertebrates in a mixed-land-use watershed. The experiment utilized a scale-nested design by delineating a large watershed into multiple sub-watersheds based on pour points to capture upstream effects of land use on the sample location. At the single-stream scale, there were inherent limitations. Study sites within WRW had fairly similar land use, making it more difficult to detect relationships between macroinvertebrate composition and land use than when comparing urban vs wildland watersheds. Also, due to having a limited number of samples, all mainstem sites were treated as statistically independent in order to preserve statistical power. This likely violated the independence assumption for all statistical analyses. Repeated sampling of the same sites through time (across four years) was taken into account with repeatedmeasures ANOVA, but it was not possible to consider potential temporal relationships in the multiple regressions.

Although macroinvertebrates naturally reflect stream condition over time, water chemistry variables in this study only represent a single snapshot in time during data collection. Finally, since most of the data collection occurred outside the sampling window for summer WVSCI and GLIMPSS, this study's WVSCI and GLIMPSS scores could not be compared to the state's reference standards. 


\section{Summary \& Conclusions}

While aquatic macroinvertebrates have been widely used as bioindicators to classify stream condition, there is relatively little information pertaining to the use of aquatic macroinvertebrates as a tool in classifying stream condition in mixed-land-use watersheds (Nichols et al. 2016). This study was among the first to contribute new data of how mixed landuse impacts the ecological integrity of a single, first-order stream in an urbanizing Appalachian watershed.

This study detected significant influences of environmental variables on macroinvertebrate community composition. Specifically, CCA identified relationships between community composition, land use characteristics, habitat variables, water quality (NPDES), and macroinvertebrate indices were most sensitive to in-stream water quality variables. However, some of the relationships were inconsistent with previous findings. No environmental predictor variable was significant in more than one year for a given response variable but in many instances, this variable was significant in the repeated measures ANOVA utilizing all years. For example, pH was a significant predictor for WVSCI in 2017, but not in any other year. With only ten data points per year, and variability in measured environmental data from year to year, relationships between the environmental variables and the macroinvertebrate community were not consistently detectable. This supports more frequent measurement of water chemistry variables. Monitoring over multiple years may be more reliable in capturing the temporal fluctuation of macroinvertebrate communities as well as instantaneous environmental variables. An area for exploration would be to investigate the effects tributaries have on main channels within urbanizing watersheds. The success in identifying environmental stressors using macroinvertebrates as bioindicators may be enhanced in tributaries rather than mainstem locations since there are fewer confounding upstream influences contributing to dilution and mixing of materials (sediments, ions, etc.). This would also solve the problem of spatial dependence between sites for statistical analyses because different tributaries and associated sub-watersheds are independent of each other. Understanding the influence of tributaries to mainstem stream condition could be useful for managers that want to target tributary remediation.

While geochemical differences in West Run sites were attributed to the loss of forest and riparian cover in a previous study (Kellner et al. 2018), this study was not able to detect significant differences of macroinvertebrate communities based on forest cover. This was mainly due to the narrow range of forest cover present in the sub-watersheds studied. However, the 
ordination diagrams revealed that higher densities of discharge outlets correlated negatively with forest cover, which could be due to urbanization. Additionally, findings indicated that streamwater quality variables such as conductivity, TDS, and $\mathrm{pH}$ consistently predicted poor stream condition within WRW. This suggests that the effects of past mining are still prevalent, and perhaps the most influential stressor to West Run. The response of macroinvertebrates to some physical habitat parameters (e.g., sedimentation) were not as expected, so it is possible that they were overridden by other factors (i.e., water chemistry). This may also explain why land use commonly was not a significant predictor of stream condition, even though it likely affects the quality of physical habitat, thus also influencing macroinvertebrate composition. Future studies in WRW should put more emphasis on streamwater physicochemical variables since physical habitat variables were confounding in this study. Further research using a scalenested design should focus on the influence tributaries have on receiving waters. This will help isolate variables that would otherwise be weakened on mainstem reaches and eliminate statistical limitations.

Findings from this study suggest that the effects from mining and urban development are the most common stressors in WRW. More specifically, low pH, elevated conductivity and TDS, as well as higher storm water and sewage outlet density corresponded to more stream impairment. The effects of urban development can be mitigated through watershed-scale urban forestry and storm water management. The West Virginia Department of Environmental Protection (WVDEP) recommends various kinds of storm water management structures to intercept surface runoff and increase infiltration before it reaches the stream or river. For example, bioretention areas (e.g., rain gardens) have the capacity to remove up to $81 \%$ of total suspended solids (TSS) and 51-71\% of other metals (e.g., lead) (WVDEP 2006). Historically, there has been little mitigation of AMD in WRW. The 2008 West Run Watershed Based Plan indicated that the mining drainage entering the Site 4 tributary was being treated with limestone riprap channels; however, the effectiveness of the treatment has not been determined. The findings presented in this study suggest that watershed management in mining-impacted, mixed land use watersheds should focus on mitigating the effects of urbanization and past mining activities by improving storm water management and implementing treatments for AMD. Macroinvertebrate community composition, expressed either as composite index or individual functional types, can be a tool to monitor deterioration or improvement of stream condition in sub-watersheds of urbanizing mixed-land-use watersheds. 


\section{Literature Cited}

Alexander, R. B., E. W. Boyer, R. A. Smith, G. E. Schwars, and R. B. Moore. 2007. The role of headwater streams in downstream water quality. Journal of the American Water Resource Association 43:41-59.

Allan, J. D. 2004. Landscapes and riverscapes: The influence of land use on stream ecosystems. Annual Review of Ecology, Evolution, and systematics 35:257-384.

Barbour, M.T., J. Gerritsen, B.D. Snyder, J.B. Stribling. 1999. Rapid bioassessment protocols for use in wadeable streams and rivers: Periphyton, benthic macroinvertebrates, and fish. Second Edition. United States Environmental Protection Agency. EPA/841/B-99002.

Bazinet, N. L., B. M. Gilbert., and A. M. Wallace. 2010. A comparison of urbanization effects on stream benthic macroinvertebrates and water chemistry in an Urban and Urbanizing Basin in Southern Ontario, Canada. Water Quality Research Journal of Canada 45: 327341.

Beasley, G., and P. Kneale. 2002. Reviewing the impact of metals and PAHs on macroinvertebrates in urban watercourses. Progress in Physical Geography 26:236-270.

Benjamini, Y., and Y. Hochberg. 1995. Controlling the false discovery rate: a practical and powerful approach to multiple testing. Journal of the Royal Statistical Society B 57: 289300.

Bolund, P., and S. Hunhammar. 1999. Ecosystem services in urban areas. Ecological Economics 29:293-301.

Bonada, N., N. Prat, V. H. Resh, and B. Statzner. 2006. Developments in aquatic insect biomonitoring: A comparative analysis of recent approaches. Annual Review of Entomology 51:495-523.

Boyd, C. E. 2015. Water quality. Second Edition. Springer International.

Boyer, E. W., C. L. Goodale, N. A. Jaworski, and R. W. Howarth. 2002. Anthropogenic nitrogen sources and relationships to riverine nitrogen export in the northeastern U.S.A. Biogeochemistry 57/58:137-169.

Brown, T. C., and P. Froemke. 2012. Nationwide assessment of nonpoint source threats to water quality. BioScience 62:136-146.

Caissie, D. 2006. The thermal regime of rivers: A review. Freshwater Biology 51:1389-1406.

Cao, X., L. Chai, D. Jiang, J. Wang, Y. Liu, and Y. Huang. 2018. Loss of biodiversity alters ecosystem function in freshwater streams: potential evidence from benthic macroinvertebrates. Ecosphere 9:1-17. 
Castela, J., V. Ferreira, and M. A. S. Graça. 2008. Evaluation of stream ecological integrity using litter decomposition and benthic invertebrates. Environmental Pollution 153:440449.

Chang, F. H., J. E. Lawrence, B. Rios-Touma, and V. H. Resh. 2014. Tolerance values of benthic macroinvertebrates for stream biomonitoring: Assessment of assumptions underlying scoring systems worldwide. Environmental Monitoring and Assessment 186:2135-2149.

Chase, J. W., G. A. Benoy, S. W. R. Hann, and J. M. Culp. 2016. Small differences in riparian vegetation significantly reduce land use impacts on stream flow and water quality in small agricultural watersheds. Journal of Soil and Water Conservation 71:194-205.

Clements, W. H. 1999. Metal tolerance and predator-prey interactions in benthic macroinvertebrate stream communities. Ecological Applications 9:1073-1084.

Cormier, S. M., G. W. II Suter, and L. Zheng. 2012. Derivation of a benchmark for freshwater ionic strength. Environmental Toxicology and Chemistry 32:263-271.

Cormier, S. M., S. P. Wilkes, and L. Zheng. 2013. Relationship of land use and elevated ionic strength in Appalachian watersheds 32:296-303.

Covich, A. P., M. A. Palmer, and T. A. Crowl. 1999. The role of benthic invertebrate species in freshwater ecosystems: Zoobenthic species influence energy flows and nutrient cycling. BioScience 49:119-127.

Cummins, K.W. 1973. Trophic relations of aquatic insects. Annual review of Entomology 18:183-206.

Cummins, K. W., and M. J. Klug. 1979. Feeding ecology of stream invertebrates. Annual Review of Ecology and Systematics 10:147-172.

Dallas, H. F., and N. A. Rivers-Moore. 2012. Critical thermal maxima of aquatic macroinvertebrates: Towards identifying bioindicators of thermal alteration. Hydrobiologia 679:61-76.

Dodds, W. and Whiles, M. 2010. Freshwater Ecology: Concepts and environmental applications of limnology. Second Edition. Elsevier Inc.

Freund, J. G. and J. T. Petty. 2007. Response of fish and macroinvertebrate bioassessment indices to water chemistry in a mined Appalachian watershed. Environmental Management 39:707-720.

Fu, L., Y. Jiang, J. Ding, Q. Liu, Q. Peng, and M. Kang. 2016. Impacts of land use and environmental factors on macroinvertebrate functional feeding groups in the Dongjiang River basin, southeast Ching. Journal of Freshwater Ecolgoy 31:21-35. 
Gerritsen, J., Burton, J., \& Barbour, M. T. 2000. A stream condition index for West Virginia wadeable streams. Owing Mills: Tetra Tech, Inc.

Green, P. A., C. J. Vörösmarty, I. Harrison, T. Farrell, L. Sáenz, and B. M. Fekete. 2015. Freshwater ecosystem services supporting humans: Pivoting from water crisis to water solutions. Global Environmental Change 34:108-118.

Grizzetti, B., D. Lanzanova, C. Liquete, A. Reynaud, and A. C. Cardoso. 2016. Assessing water ecosystem services for water resource management. Environmental Science and Policy 61:194-203.

Heino, J. 2005. Functional biodiversity of macroinvertebrate assemblages along major ecological gradients of boreal headwater streams. Freshwater Biology 50:1578-1587.

Hester, E. T., and M. W. Doyle. 2011. Human impacts to river temperature and their effects on biological processes: A quantitative synthesis. Journal of the American Water Resources Association 47:571-587.

Hilsenhoff, W. L. 1987. The great lakes entomologist: an improved biotic index of organic stream pollution. The Great Lakes Entomologist 20:31-39.

Homer, C., J. Dewitz, S. Jin, G. Xian, C. Costello, P. Danielson, L. Gass, M. Funk, J. Wickham, S. Stehman, R. Auch, and K. Riitters. 2020. Conterminous United States land cover change patterns 2001-2016 from the 2016 National Land Cover Database. ISPRS Journal of Photogrammetry and Remote Sensing 162:184-199.

Horne, J. P. and J. A. Hubbart. 2020. A spatially distributed investigation of stream water temperature in a contemporary mixed-land-use watershed. Water 12:1756.

Karr, J. R. 1991. Biological integrity: a long-neglected aspect of water resource management. Ecological Applications 1:66-84.

Kellner, E., J. Hubbart, K. Stephan, E. Morrissey, Z. Freedman, E. Kutta, and C. Kelly. 2018. Characterization of sub-watershed-scale stream chemistry regimes in an Appalachian mixed-land-use watershed. Environmental Monitoring and Assessment 190.

Lenat, D. R., and J. K. Crawford. 1994. Effects of land use on water quality and aquatic biota of three North Carolina Piedmont streams. Hydrobiologia 294:185-199.

Leszczyska, J., L. Gowacki, and M. Grzybkowska. 2017. Factors shaping species richness and biodiversity of riverine macroinvertebrate assemblages at the local and regional scale. Community Ecology 18:227-236.

MacDonald, L. H., and D. Coe. 2007. Influence of headwater streams on downstream reaches in forested areas. Forest Science 53(2):148-168. 
Matteo, M., T. Randhir, and D. Bloniarz. 2006. Watershed-scale impacts of forest buffers on water quality and runoff in urbanizing environment. Journal of Water Resources Planning and Management 132:144-152.

Merriam, E. R., J. T. Petty, G. T. Merovich, J. B. Fulton, and M. P. Strager. 2011. Additive effects of mining and residential development on stream conditions in a central Appalachian watershed. Journal of the North American Benthological Society 30:399418.

Merritt, R.W., K.W. Cummins, and M. B. Berg. 2019. An introduction to the aquatic insects of North America. Fifth Edition. Kendall Hunt Publishing Company, lowa.

Meyer, J. L., and J.B. Wallace. 2001. Lost linkages and lotic ecology: Rediscovering small streams. P. 295-317 in Ecology: achievement and challenge, M.C. Huntly and N.J. Levin (eds.). Blackwell Scientific, Oxford, UK.

Nichols, J., J. A. Hubbart, and B. C. Poulton. 2016. Using macroinvertebrate assemblages and multiple stressors to infer urban stream system condition: a case study in the central US. Urban Ecosystems 19:679-704.

Olson, J. R. and C. P. Hawkins. 2017. Effects of total dissolved solids on growth and mortality predict distributions of stream macroinvertebrates. Freshwater Biology 62:779-791.

Peterson, F. and J. A. Hubbart. 2020. Advancing understanding or land use and physicochemical impacts on fecal contamination in mixed-land-use watersheds. Water $12: 1094$.

Petty, J. T., J. B. Fulton, M. P. Strager, G.T. Merovich, J. M. Stiles, and P. F. Ziemkiewicz. 2010. Landscape indicators and thresholds of stream ecological impairment in an intensively mined Appalachian watershed. Journal of the North American Benthological Society 29:1292-1309.

Poff, N. L., J.D. Olden, N. K. Viera, D. S. Finn, M. P. Simmons, and B. C. Kondratieff. 2006. Functional trait niches of North American lotic insects: trait-based ecological applications in light of phylogenetic relationships. Journal of North American Bethological Society 25: 730-755.

Poff, N. L. R., B. P. Bledsoe, and C. O. Cuhaciyan. 2006. Hydrologic variation with land use across the contiguous United States: Geomorphic and ecological consequences for stream ecosystems. Geomorphology 79:264-285.

Pond, G. J., J. E. Bailey, B. Lowman, and M. J. Whitman. 2011. The West Virginia GLIMPSS (genus-level index of most probable stream status): a benthic macroinvertebrate index of biotic integrity for West Virginia's wadeable streams. West Virginia Department of 
Environmental Protection, Division of Water and Waste Management, Watershed Assessment Branch, Charleston, WV.

Pond, G. J., J. E. Bailey, B. Lowman, and M. J. Whitman. 2012. Calibration and validation of a regionally and seasonally stratified macroinvertebrate index for West Virginia wadeable streams. Environmental Monitoring and Assessment 185:1515-1540.

Pond, G. J., M. E. Passmore, F. A. Borsuk, L. Reynolds, and C. J. Rose. 2008. Downstream effects of mountaintop coal mining: comparing biological conditions using family- and genus-level macroinvertebrate bioassessment tools. Journal of the North American Benthological Society 27:717-737.

Purcell, A. H., D. W. Bressler, M. J. Paul, M. T. Barbour, E. T. Rankin, J. L. Carter, and V. H. Resh. 2009. Assessment tools for urban catchments: Developing biological indicators based on benthic macroinvertebrates. Journal of the American Water Resources Association 45:306-319.

Quinn, J. M., G. L. Steele, C. W. Hickey, and M. L. Vickers. 1994. Upper thermal tolerances of twelve New Zealand stream invertebrate species. New Zealand Journal of Marine and Freshwater Research 28:391-397.

Rabení C. F., K. E. Doisy, and L. D. Zweig. 2005. Steam invertebrate community functional responses to deposited sediment. Aquatic Sciences 67: 395-402.

Richards, C., R. J. Haro, L. B. Johnson, and G. E. Host. 1997. Catchment and reach-scale properties as indicators of macroinvertebrate species traits. Freshwater Biology 37:219230.

Riley, C., S. Inamdar, and C. Pennuto. 2007. Use of benthic macroinvertebrate indices to assess aquatic health in a mixed-landuse watershed. Journal of Freshwater Ecology 22:539-551.

Roy, A. H., A. D. Rosemond, D. S. Leigh, M. J. Paul, and J. B. Wallace. 2003. Habitat-specific responses of stream insects to land cover disturbance: biological consequences and monitoring implications. Journal of the North American Benthological Society 22:292307.

Roy A. H., A. D. Rosemond, M.J. Paul, D. S. Leigh, and J. B. Wallace. 2003. Stream macroinvertebrate response to catchment urbanization (Georgia, U.S.A). Freshwater Biology 48:329-346.

Shannon, C. E. and W. Weaver. 1949. The mathematical theory of communication. University of Illinois Press, Urbana. 
Sheldon, F., C. Leigh, W. Neilan, M. Newham, C. Polson, and W. Hadwen. 2019. Urbanization. Pages 229-248 Approaches to Water Sensitive Urban Design. Elsevier.

Storey, R. G., and D. R. Cowley. 1997. Recovery of three New Zealand rural streams as they pass through native forest remnants. Hydrobiologia 353:63-76.

Strager, M. P. and A. E. Maxwell. 2018. WV Land Use Land Cover NAIP Derived 2016. Natural Resource Analysis Center, West Virginia University, Morgantown, WV. Available at: https://wvgis.wvu.edu/data/dataset.php?ID=489

ter Braak, C. J. F. and Šmilauer, P. 2018. Canoco reference manual ans user's guide: Software for ordination (version 5.10). Microcomputer Power (Ithaca, NY, USA), 536 pp.

Vander Laan, J. J., C. P. Hawkins, J. R. Olson, and R. A. Hill. 2013. Linking land use, in-stream stressors, and biological condition to infer causes of regional ecological impairment in streams. Freshwater Science 32(8):801-820.

Vannote, R. L., G. W. Minshall, K. W. Cummins, J. R. Sedell, and C. E. Cushing. 1980. The river continuum concept. Can, J. Fish. Aquat. Sci. 37: 130-137.

Vörösmarty, C. J., P. B. Mclntyre, M. O. Gessner, D. Dudgeon, A. Prusevich, P. Green, S. Glidden, S. E. Bunn, C. A. Sullivan, C. R. Liermann, and P. M. Davies. 2010. Global threats to human water security and river biodiversity. Nature 467:555-561.

Wallace, J. B., and J. R. Webster. 1996. The role of macroinvertebrates in stream ecosystem function. Annual review of entomology 41:115-139.

Walters, D. M., A. H. Roy, and D. S. Leigh. 2009. Environmental indicators of macroinvertebrate and fish assemblage integrity in urbanizing watersheds. Ecological Indicators 9:12221233.

West Virginia Water Research Institute (WVWRI) and the West Run Watershed Association. 2008. Watershed Based Plan for West Run of the Monongahela River. 59 pp.

WVDEP (West Virginia Department of Environmental Protection). 2006. Stormwater Management Structure Guidance Document. Groundwater/UIC Program.

WVDEP (West Virginia Department of Environmental Protection). 2012. Final West Virginia integrated water quality monitoring and assessment report. In 237 pp.

WVDEP (West Virginia Department of Environmental Protection). 2014. Final West Virginia integrated water quality monitoring and assessment report. In 254 pp.

WVDEP (West Virginia Department of Environmental Protection). 2016. Final West Virginia integrated water quality monitoring and assessment report. In 290 pp. 
WVDEP (West Virginia Department of Environmental Protection). 2018. Watershed Assessment Branch 2018 Field Sampling Standard Operating Procedures. Division of Water and Waste Management, Watershed Assessment Branch, Charleston, WV.

WVDEP (West Virginia Department of Environmental Protection). 2020. NPDES Outlets. https://tagis.dep.wv.gov/site/GISData 


\section{Appendix}

Table A1. Physical habitat assessment sheet used in data collection (Barbour et al. 1999).

HABITAT ASSESSMENT FIELD DATA SHEET-HIGH GRADIENT STREAMS (FRONT)

\begin{tabular}{|l|l|l|}
\hline STREAM NAME & LOCATION \\
\hline STATION \#_ & STREAM CLASS \\
\hline LAT_ RIVERMTLE_ & RIVER BASIN \\
\hline STORET \# & AGENCY \\
\hline INVESTIGATORS & $\begin{array}{l}\text { DATE } \\
\text { TIME }\end{array}$ \\
\hline FORM COMPLETED BY & AM PM & REASON FOR SURVEY \\
\hline
\end{tabular}

\begin{tabular}{|c|c|c|c|c|c|}
\hline & & & Condition & Category & \\
\hline & Parameter & Optimal & SuboptimaI & Marginal & Poor \\
\hline & $\begin{array}{l}\text { 1. Epifaunal } \\
\text { Substrate' } \\
\text { Available Cover }\end{array}$ & $\begin{array}{l}\text { Greater than } 70 \% \text { of } \\
\text { substrate favorable for } \\
\text { cpifaunal colonization } \\
\text { and fish cover; mix of } \\
\text { snags, submerged logs, } \\
\text { undercut banks, cobble } \\
\text { or other stable habitat } \\
\text { and at stage to allow full } \\
\text { colonization potential } \\
\text { (i.e., logs/snags that are } \\
\text { nof new fall and not } \\
\text { transient). }\end{array}$ & $\begin{array}{l}40-70 \% \text { mix of stable } \\
\text { habitat; well-suited for } \\
\text { full colonization } \\
\text { potential; adequate } \\
\text { habitat for maintenance } \\
\text { of populations; presence } \\
\text { of additional substrate in } \\
\text { the form of newfall, but } \\
\text { not yet prepared for } \\
\text { colonization (may rate at } \\
\text { high end of scale). }\end{array}$ & $\begin{array}{l}20-40 \% \text { mix of stable } \\
\text { habitat; habitat } \\
\text { availability less than } \\
\text { desirable; substrate } \\
\text { frequently disturbed or } \\
\text { removed. }\end{array}$ & $\begin{array}{l}\text { Less than } 20 \% \text { stable } \\
\text { habitat; lack of habitat is } \\
\text { obvious; substrate } \\
\text { unstable or lacking. }\end{array}$ \\
\hline & SCORE & $20 \quad 19 \quad 18012 \quad 16$ & $15 \quad 14,13 \cdot 12 \quad 1 K_{2}$ & $10 \times 298676$ & \\
\hline 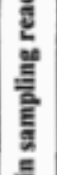 & 2. Embeddedness & $\begin{array}{l}\text { Gravel, cobble, and } \\
\text { boulder particles are } 0 \text { - } \\
25 \% \text { surrounded by fine } \\
\text { sediment. Layering of } \\
\text { cobble provides diversity } \\
\text { of niche space. } \\
\end{array}$ & $\begin{array}{l}\text { Gravel, cobble, and } \\
\text { boulder particles are } 25 \text { - } \\
50 \% \text { surrounded by fine } \\
\text { sediment. }\end{array}$ & $\begin{array}{l}\text { Gravel, cobble, and } \\
\text { boulder particles are } 50- \\
75 \% \text { surrounded by fine } \\
\text { sediment. }\end{array}$ & $\begin{array}{l}\text { Gravel, cobble, and } \\
\text { boulder particles are } \\
\text { more than } 75 \% \\
\text { surrounded by fine } \\
\text { sediment. }\end{array}$ \\
\hline $\bar{z}$ & SCORE & $203619)(8,17316$ & 11 & 3 & \\
\hline 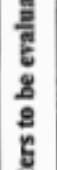 & $\begin{array}{l}\text { 3. Velocity/Depth } \\
\text { Regime }\end{array}$ & $\begin{array}{l}\text { All four velocity/depth } \\
\text { regimes present (slow- } \\
\text { deep, slow-shallow, fast- } \\
\text { deep, fast-shallow). } \\
\text { (Slow is }<0.3 \mathrm{~m} / \mathrm{s} \text {, deep } \\
\text { is }>0.5 \mathrm{~m} \text {.) } \\
\end{array}$ & $\begin{array}{l}\text { Only } 3 \text { of the } 4 \text { regimes } \\
\text { present (if fast-shallow is } \\
\text { missing, score lower } \\
\text { than if missing other } \\
\text { regimes). }\end{array}$ & $\begin{array}{l}\text { Only } 2 \text { of the } 4 \text { habitat } \\
\text { regimes present (if fast- } \\
\text { shallow or slow-shallow } \\
\text { are missing, score low). }\end{array}$ & $\begin{array}{l}\text { Dominated by } 1 \\
\text { velocity/ depth regime } \\
\text { (usually slow-deep). }\end{array}$ \\
\hline & SCORE & $20, \quad 99218 \quad 17 \quad 16$ & $15,140,13,12$ & $10,9438=7$ & 20 1. 0 \\
\hline 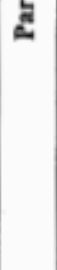 & $\begin{array}{l}\text { 4. Sediment } \\
\text { Deposition }\end{array}$ & $\begin{array}{l}\text { Little or no enlargement } \\
\text { of islands or point bars } \\
\text { and less than } 5 \% \text { of the } \\
\text { bottom affected by } \\
\text { sediment deposition. }\end{array}$ & $\begin{array}{l}\text { Some new increase in } \\
\text { bar formation, mostly } \\
\text { from gravel, sand or fine } \\
\text { sediment; } 5-30 \% \text { of the } \\
\text { bottom affected; slight } \\
\text { deposition in pools. }\end{array}$ & $\begin{array}{l}\text { Moderate deposition of } \\
\text { new gravel, sand or fine } \\
\text { sediment on old and new } \\
\text { bars; } 30-50 \% \text { of the } \\
\text { bottom affected; } \\
\text { sediment deposits at } \\
\text { obstructions, } \\
\text { constrictions, and bends; } \\
\text { moderate deposition of } \\
\text { pools prevalent. }\end{array}$ & $\begin{array}{l}\text { Heavy deposits of fine } \\
\text { material, increased bar } \\
\text { development; more than } \\
50 \% \text { of the bottom } \\
\text { changing frequently; } \\
\text { pools almost absent due } \\
\text { to substantial sediment } \\
\text { deposition. }\end{array}$ \\
\hline & SCORE & $20 \quad 19 \quad 18: 17$ & $15 \mathrm{Cl} 14,13,72 \mathrm{~s}$ & 10549897 & \\
\hline & $\begin{array}{l}\text { 5. Channel Flow } \\
\text { Status }\end{array}$ & $\begin{array}{l}\text { Water reaches base of } \\
\text { both lower banks, and } \\
\text { minimal amount of } \\
\text { channel substrate is } \\
\text { exposed. }\end{array}$ & $\begin{array}{l}\text { Water fills }>75 \% \text { of the } \\
\text { available channel; or } \\
25 \% \text { of channel } \\
\text { substrate is exposed. }\end{array}$ & $\begin{array}{l}\text { Water fills } 25-75 \% \text { of } \\
\text { the available channel, } \\
\text { and/or riffle substrates } \\
\text { are mostly exposed. }\end{array}$ & $\begin{array}{l}\text { Very little water in } \\
\text { channel and mostly } \\
\text { present as standing } \\
\text { pools. }\end{array}$ \\
\hline & SCORE & $20-6918=17436$ & $15214 \quad 13,12 \quad 11$ & & 5 \\
\hline
\end{tabular}


HABITAT ASSESSMENT FIELD DATA SHEET-HIGH GRADIENT STREAMS (BACK)

\begin{tabular}{|c|c|c|c|c|c|}
\hline \multirow{2}{*}{\multicolumn{2}{|c|}{$\begin{array}{c}\text { Habitat } \\
\text { Parameter }\end{array}$}} & \multicolumn{4}{|c|}{ Condition Category } \\
\hline & & Optimal & Suboptimal & Marginal & Poor \\
\hline \multirow{13}{*}{ 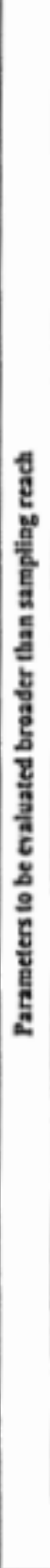 } & $\begin{array}{l}\text { 6. Channel } \\
\text { Atteration }\end{array}$ & $\begin{array}{l}\text { Channelization or } \\
\text { dredging absent or } \\
\text { minimal; stream with } \\
\text { normal pattern. }\end{array}$ & $\begin{array}{l}\text { Some channelization } \\
\text { present, usually in areas } \\
\text { of bridge abutments; } \\
\text { evidence of past } \\
\text { channelization, i.e., } \\
\text { dredging, (greater than } \\
\text { past } 20 \text { yr) may be } \\
\text { present, but recent } \\
\text { channelization is not } \\
\text { present. }\end{array}$ & $\begin{array}{l}\text { Channelization may be } \\
\text { extensive; embanikments } \\
\text { or shoring structures } \\
\text { present on both banks; } \\
\text { and } 40 \text { to } 80 \% \text { of stream } \\
\text { reach channelized and } \\
\text { disrupted. }\end{array}$ & $\begin{array}{l}\text { Banks shored with } \\
\text { gabion or cement; over } \\
80 \% \text { of the stream reach } \\
\text { channelized and } \\
\text { disrupted. Instream } \\
\text { habitat greatly altered or } \\
\text { removed entirely. }\end{array}$ \\
\hline & SCORE & $\begin{array}{lllll}20 & 19 & 18 & 17 & 16 \\
\end{array}$ & $\begin{array}{lllll}15 & 14 & 13 & 12 & 11\end{array}$ & $\begin{array}{lllll}10 & 9 & 8 & 7 & 6\end{array}$ & $\begin{array}{llllll}5 & 4 & 3 & 2 & 1 & 0\end{array}$ \\
\hline & $\begin{array}{l}\text { 7. Frequency of } \\
\text { Rifles (or bends) }\end{array}$ & $\begin{array}{l}\text { Oecurrence of riffles } \\
\text { relatively frequent; ratio } \\
\text { of distance between } \\
\text { rifnes divided by width } \\
\text { of the stream } 47: 1 \\
\text { (generally } 5 \text { to } 7 \text {; } \\
\text { variety of habitat is key. } \\
\text { In streams where riffles } \\
\text { are continuous, } \\
\text { placement of boulders or } \\
\text { other large, natural } \\
\text { obstruction is important. }\end{array}$ & $\begin{array}{l}\text { Oecurrence of riffles } \\
\text { infrequent; distance } \\
\text { between rimes divided } \\
\text { by the width of the } \\
\text { stream is between } 7 \text { to } \\
15 \text {. }\end{array}$ & $\begin{array}{l}\text { Occasional riffle or } \\
\text { bend; bottom contours } \\
\text { provide some habitat; } \\
\text { distance between riffles } \\
\text { divided by the width of } \\
\text { the stream is between is } \\
\text { to } 25 \text {. }\end{array}$ & $\begin{array}{l}\text { Generally all flat water } \\
\text { or shallow riffles; poor } \\
\text { habitat; distance between } \\
\text { rimes divided by the } \\
\text { width of the stream is a } \\
\text { ratio of }>25 \text {. }\end{array}$ \\
\hline & SCORE & $\begin{array}{lllll}20 & 19 & 18 & 17 & 16 \\
\end{array}$ & $\begin{array}{lllll}15 & 14 & 13 & 12 & 11 \\
\end{array}$ & $\begin{array}{lllll}10 & 9 & 8 & 7 & 6 \\
\end{array}$ & $\begin{array}{llllll}5 & 4 & 3 & 2 & 1 & 0 \\
\end{array}$ \\
\hline & $\begin{array}{l}\text { 8. Bank Stablilty } \\
\text { (score each bank) } \\
\text { Note: determine lef } \\
\text { or right side by } \\
\text { facing downstream. }\end{array}$ & $\begin{array}{l}\text { Banks stable; evidence } \\
\text { of erosion or bank } \\
\text { failure absent or } \\
\text { minimal; little potential } \\
\text { for future problems. } \\
<5 \% \text { of bank affected. }\end{array}$ & $\begin{array}{l}\text { Moderately stable; } \\
\text { infrequent, small areas of } \\
\text { erosion mostly healed } \\
\text { over. } 5-30 \% \text { of bank in } \\
\text { reach has areas of } \\
\text { erosion. }\end{array}$ & $\begin{array}{l}\text { Moderately unstable; } 30 \text { - } \\
60 \% \text { of bank in reach has } \\
\text { areas of erosion; high } \\
\text { erosion potential during } \\
\text { floods. }\end{array}$ & $\begin{array}{l}\text { Unstable; many eroded } \\
\text { areas; "raw" areas } \\
\text { frequent along straight } \\
\text { sections and bends; } \\
\text { obvious bank sloughing: } \\
60-100 \% \text { of bank has } \\
\text { erosional scars. }\end{array}$ \\
\hline & SCORE__(LB) & Left Bank 10 & 7 & 4 & 1 \\
\hline & SCORE _ & Right Bank 10 & 7 & $4 \quad 3$ & $\begin{array}{lll}2 & 1 & 0\end{array}$ \\
\hline & $\begin{array}{l}\text { 9. Vegetative } \\
\text { Protection (seore } \\
\text { cach bank) }\end{array}$ & $\begin{array}{l}\text { More than } 90 \% \text { of the } \\
\text { streambank surfaces and } \\
\text { immediate riparian zone } \\
\text { covered by native } \\
\text { vegetation, including } \\
\text { trees, understory shrubs, } \\
\text { or nonwoody } \\
\text { macrophytes; vegetative } \\
\text { disruption through } \\
\text { grazing or mowing } \\
\text { minimal or not evident; } \\
\text { aimost all plants allowed } \\
\text { to grow naturally. } \\
\end{array}$ & $\begin{array}{l}70-90 \% \text { of the } \\
\text { streambank surfaces } \\
\text { covered by native } \\
\text { vegetation, but one class } \\
\text { of plants is not well- } \\
\text { represented; disnuption } \\
\text { evident but not affecting } \\
\text { full plant growth } \\
\text { potential to any great } \\
\text { extent; more than one- } \\
\text { half of the potential plant } \\
\text { stubble height } \\
\text { remaining. }\end{array}$ & $\begin{array}{l}50-70 \% \text { of the } \\
\text { streambank surfaces } \\
\text { covered by vegetation; } \\
\text { disruption obvious; } \\
\text { patches of bare soil or } \\
\text { closely cropped } \\
\text { vegetation common; less } \\
\text { than one-haif of the } \\
\text { potential plant stubble } \\
\text { height remaining. }\end{array}$ & $\begin{array}{l}\text { Less than } 50 \% \text { of the } \\
\text { streambank surfaces } \\
\text { covered by vegetation; } \\
\text { disruption of streambank } \\
\text { vegetation is very high; } \\
\text { vegetation has been } \\
\text { removed to } \\
5 \text { centimeters or less in } \\
\text { average stubble height. }\end{array}$ \\
\hline & SCORE __ (LB) & Lef Bank 10 & 7 & $4-3$ & $2 \quad 1 \quad 0$ \\
\hline & SCORE__(RB) & Right Bank 10 & 6 & 4.3 & $2-1$ \\
\hline & $\begin{array}{l}\text { 10. Riparian } \\
\text { Yegetative Zone } \\
\text { Width (score each } \\
\text { bank riparian zone) }\end{array}$ & $\begin{array}{l}\text { Width of riparian zone } \\
>18 \text { meters; human } \\
\text { activities (i.e, parking } \\
\text { lots, roadbeds, clear- } \\
\text { cuts, lawns, or crops) } \\
\text { have not impacted zone. }\end{array}$ & $\begin{array}{l}\text { Width of riparian zone } \\
12-18 \text { meters; human } \\
\text { activities have impacted } \\
\text { zone only minimally. }\end{array}$ & $\begin{array}{l}\text { Width of riparian zone } \\
6-12 \text { meters; human } \\
\text { activities have impacted } \\
\text { zone a great deal. }\end{array}$ & $\begin{array}{l}\text { Width of riparian zone } \\
<6 \text { meters: little or no } \\
\text { riparian vegetation due } \\
\text { to human activities. }\end{array}$ \\
\hline & SCORE__ (LB) & Left Bank 10 & 7 & 4 & $1=0$ \\
\hline & SCORE__(RB) & Right Bank 10 & 7 & 3 & 1 \\
\hline
\end{tabular}

Total Score 
Table A2. Abundance of total individuals in the subsample generated from each site sample in each year. Those marked with $\left(^{*}\right)$ were omitted in the multivariate analyses due to low sample size. The target subsample size was $200 \pm 20 \%$ (WVDEP 2018). Subsamples with fewer individuals than that reflects sites with naturally low abundances due to poor stream condition. Four samples (-) were missing from the data set (they were not collected).

\begin{tabular}{ccccc}
\hline Site & 2016 & 2017 & 2018 & 2019 \\
\hline 1 & 185 & 200 & 182 & 195 \\
2 & 113 & 29 & 25 & 143 \\
3 & 146 & 50 & - & 119 \\
4 & $6^{*}$ & 173 & - & $13^{*}$ \\
5 & $3^{*}$ & $1^{*}$ & 35 & 58 \\
6 & 76 & 203 & 204 & 202 \\
7 & 50 & 181 & 198 & 217 \\
8 & 50 & 49 & 178 & 207 \\
9 & 102 & 214 & 199 & 222 \\
10 & 193 & 199 & - & - \\
\hline
\end{tabular}


Table A3. List of all taxa found in WRW. Taxonomic rank was identified by Order, Family, and Genus, unless otherwise noted; (-) indicates the taxa was not identified to further classifications.

\begin{tabular}{|c|c|c|}
\hline Order & Family & Genus \\
\hline \multicolumn{3}{|l|}{ Insect groups } \\
\hline Coleoptera & Elmidae & Optioservus \\
\hline Coleoptera & Elmidae & Stenelmis \\
\hline Coleoptera & Hydrophilidae & Berosus \\
\hline Coleoptera & Noteridae & Notomicrus \\
\hline Coleoptera & Psephenidae & Psephenus \\
\hline Diptera & Ceratopogonidae & Atrichopogon \\
\hline Diptera & Ceratopogonidae & Bezzia \\
\hline Diptera & Ceratopogonidae & Ceratopogon \\
\hline Diptera & Ceratopogonidae & Dasyhelea \\
\hline Diptera & Ceratopogonidae & Mallochohelea \\
\hline Diptera & Ceratopogonidae & Probezzia \\
\hline Diptera & Chironomidae & - \\
\hline Diptera & Culicidae & - \\
\hline Diptera & Empididae & Hemerodromia \\
\hline Diptera & Limoniidae & Antocha \\
\hline Diptera & Muscidae & - \\
\hline Diptera & Simuliidae & Simulium \\
\hline Diptera & Tipulidae & Tipula \\
\hline Ephemeroptera & Baetidae & Baetis \\
\hline Ephemeroptera & Heptageniidae & Maccaffertium \\
\hline Hemiptera & Veliidae & Microvelia \\
\hline Hemiptera & Veliidae & Rhagovelia \\
\hline Lepidoptera & Crambidae & Elophila \\
\hline Lepidoptera & Pyralidae & - \\
\hline Megaloptera & Corydalidae & Nigronia \\
\hline Megaloptera & Sialidae & Sialis \\
\hline Odonata & Aeshnidae & Boyeria \\
\hline Odonata & Calopterygidae & Calopteryx \\
\hline Odonata & Calopterygidae & Hetaerina \\
\hline Odonata & Coenagrionidae & Argia \\
\hline Odonata & Coenagrionidae & Coenagrion \\
\hline Odonata & Cordulegastridae & Cordulegaster \\
\hline Plecoptera & Leuctridae & Leuctra \\
\hline Plecoptera & Perlodidae & Remenus \\
\hline Trichoptera & Hydropsychidae & Cheumatopsyche \\
\hline Trichoptera & Hydropsychidae & Diplectrona \\
\hline Trichoptera & Hydropsychidae & Hydropsyche \\
\hline Trichoptera & Hydroptilidae & Hydroptila \\
\hline Trichoptera & Hydroptilidae & Stactobiella \\
\hline Trichoptera & Lepidostomatidae & Lepidistoma \\
\hline Trichoptera & Leptoceridae & Oecetis \\
\hline Trichoptera & Philopotamidae & Chimarra \\
\hline Trichoptera & Phryganeidae & Agrypnia \\
\hline Trichoptera & Polycentropodidae & Polycentropus \\
\hline Trichoptera & Rhyacophilidae & Rhyacophila \\
\hline
\end{tabular}




\begin{tabular}{lll} 
Amphipoda & Gammaridae & - \\
Annelida (phylum) & Oligochaeta (sub-class) & - \\
Basommatophora & Lymnaeidae & - \\
Basommatophora & Physidae & - \\
Basommatophora & Planorbidae & - \\
Collembola & Entomobryidae & - \\
Copepod (sub-class) & - & - \\
Decapoda & Cambaridae & Cambarus \\
Isopoda & Asellidae & - \\
Littorinimorpha & Hydrobiidae & - \\
Trombidiformes & Hydrachnidae & - \\
Turbellaria (class) & - & \\
Venerida & Cyrenidae & - \\
Venerida & Sphaeriidae & - \\
\hline
\end{tabular}


Table A4. Scores of all response variables for each sample. Low scores for BI, burrowers, and collectorgatherers indicate high stream water quality. Site $\times$ year with zeros for habit and feeing group metrics are likely due to very low abundance.

\begin{tabular}{|c|c|c|c|c|c|c|c|c|c|c|}
\hline Site & Year & WVSCl & $\begin{array}{c}\text { GLIMPSS } \\
\text { (CF) }\end{array}$ & $\begin{array}{l}\text { Family } \\
\qquad \mathrm{BI}\end{array}$ & $\begin{array}{c}\text { Genus } \\
\text { BI }\end{array}$ & $\%$ Burrower & $\%$ Clinger & $\begin{array}{l}\text { \% Collector- } \\
\text { Filterer }\end{array}$ & $\begin{array}{l}\text { \% Collector- } \\
\text { Gatherer }\end{array}$ & $\%$ Scraper \\
\hline 1 & 2016 & 62.96 & 41.02 & 5.07 & 5.60 & 31.15 & 44.81 & 36.76 & 36.22 & 5.95 \\
\hline 1 & 2017 & 41.65 & 16.79 & 5.32 & 5.89 & 57.00 & 22.00 & 19.00 & 75.50 & 2.50 \\
\hline 1 & 2018 & 48.41 & 27.11 & 5.08 & 5.35 & 35.71 & 59.89 & 47.80 & 31.32 & 1.65 \\
\hline 1 & 2019 & 48.76 & 40.44 & 5.31 & 5.53 & 43.75 & 48.96 & 38.46 & 44.62 & 5.64 \\
\hline 2 & 2016 & 41.27 & 19.19 & 5.65 & 5.87 & 10.81 & 22.52 & 22.12 & 39.82 & 0.00 \\
\hline 2 & 2017 & 51.14 & 24.70 & 4.97 & 4.83 & 32.14 & 60.71 & 55.17 & 20.69 & 0.00 \\
\hline 2 & 2018 & 46.51 & 15.45 & 5.16 & 5.56 & 72.00 & 28.00 & 20.00 & 48.00 & 8.00 \\
\hline 2 & 2019 & 49.51 & 32.07 & 5.73 & 5.72 & 29.71 & 13.04 & 11.19 & 33.57 & 0.70 \\
\hline 3 & 2016 & 61.97 & 37.88 & 4.93 & 5.44 & 10.64 & 86.52 & 77.78 & 9.03 & 6.94 \\
\hline 3 & 2017 & 47.67 & 25.77 & 5.38 & 5.56 & 44.68 & 46.81 & 30.00 & 48.00 & 14.00 \\
\hline 3 & 2019 & 55.11 & 43.41 & 5.00 & 5.15 & 27.35 & 62.39 & 44.54 & 26.05 & 15.97 \\
\hline 4 & 2016 & 37.64 & 14.24 & 6.00 & 6.17 & 33.33 & 50.00 & 50.00 & 50.00 & 0.00 \\
\hline 4 & 2017 & 13.38 & 0.11 & 5.95 & 5.96 & 98.84 & 0.58 & 0.58 & 98.84 & 0.00 \\
\hline 4 & 2019 & 41.95 & 14.45 & 6.54 & 6.46 & 44.44 & 33.33 & 23.08 & 53.85 & 0.00 \\
\hline 5 & 2016 & 46.65 & 32.50 & 5.00 & 4.00 & 0.00 & 100.00 & 100.00 & 0.00 & 0.00 \\
\hline 5 & 2017 & 26.45 & 11.11 & 6.00 & 6.00 & 0.00 & 0.00 & 0.00 & 0.00 & 0.00 \\
\hline 5 & 2018 & 47.36 & 34.00 & 4.89 & 5.00 & 0.00 & 100.00 & 71.43 & 0.00 & 22.86 \\
\hline 5 & 2019 & 51.93 & 28.85 & 4.91 & 5.12 & 3.51 & 89.47 & 74.14 & 1.72 & 13.79 \\
\hline 6 & 2016 & 44.07 & 25.84 & 5.82 & 5.75 & 41.18 & 54.41 & 40.79 & 48.68 & 9.21 \\
\hline 6 & 2017 & 55.06 & 40.01 & 5.57 & 5.49 & 29.51 & 59.56 & 48.28 & 35.47 & 6.40 \\
\hline 6 & 2018 & 39.63 & 18.94 & 5.42 & 5.69 & 55.94 & 41.09 & 28.43 & 54.41 & 11.27 \\
\hline 6 & 2019 & 46.53 & 32.13 & 5.24 & 5.45 & 30.69 & 65.84 & 58.91 & 31.19 & 5.94 \\
\hline 7 & 2016 & 43.53 & 21.91 & 5.14 & 5.36 & 24.00 & 76.00 & 72.00 & 22.00 & 4.00 \\
\hline 7 & 2017 & 43.98 & 24.13 & 5.42 & 5.39 & 39.44 & 54.44 & 53.04 & 38.67 & 1.10 \\
\hline 7 & 2018 & 29.88 & 22.85 & 5.37 & 5.52 & 44.44 & 54.04 & 49.49 & 42.93 & 4.55 \\
\hline 7 & 2019 & 58.39 & 47.08 & 4.98 & 5.29 & 7.01 & 89.72 & 80.65 & 5.53 & 7.37 \\
\hline 8 & 2016 & 47.83 & 24.49 & 5.22 & 5.32 & 12.00 & 82.00 & 80.00 & 12.00 & 0.00 \\
\hline 8 & 2017 & 49.00 & 29.04 & 5.27 & 5.43 & 23.40 & 72.34 & 67.35 & 20.41 & 6.12 \\
\hline 8 & 2018 & 50.01 & 30.42 & 5.37 & 5.61 & 28.24 & 68.82 & 65.73 & 26.97 & 3.93 \\
\hline 8 & 2019 & 59.61 & 34.66 & 5.07 & 5.37 & 11.76 & 86.27 & 82.13 & 12.56 & 1.93 \\
\hline 9 & 2016 & 38.01 & 15.99 & 6.24 & 6.10 & 58.43 & 14.61 & 13.73 & 51.96 & 4.90 \\
\hline 9 & 2017 & 52.88 & 28.09 & 5.23 & 5.42 & 10.14 & 83.57 & 81.78 & 7.48 & 0.93 \\
\hline 9 & 2018 & 51.51 & 24.26 & 5.22 & 5.68 & 20.81 & 72.08 & 70.35 & 23.62 & 0.00 \\
\hline 9 & 2019 & 52.82 & 27.82 & 5.76 & 5.95 & 54.22 & 34.34 & 21.17 & 50.90 & 0.90 \\
\hline 10 & 2016 & 47.39 & 20.81 & 5.22 & 5.94 & 47.87 & 19.15 & 17.10 & 79.27 & 1.55 \\
\hline 10 & 2017 & 45.20 & 21.42 & 5.23 & 5.47 & 36.36 & 61.11 & 57.29 & 34.67 & 0.50 \\
\hline
\end{tabular}


Figure A1. Photo log sorted alphabetically by furthest taxonomic identification. Refer to Table A4 for further details on taxonomic rank.

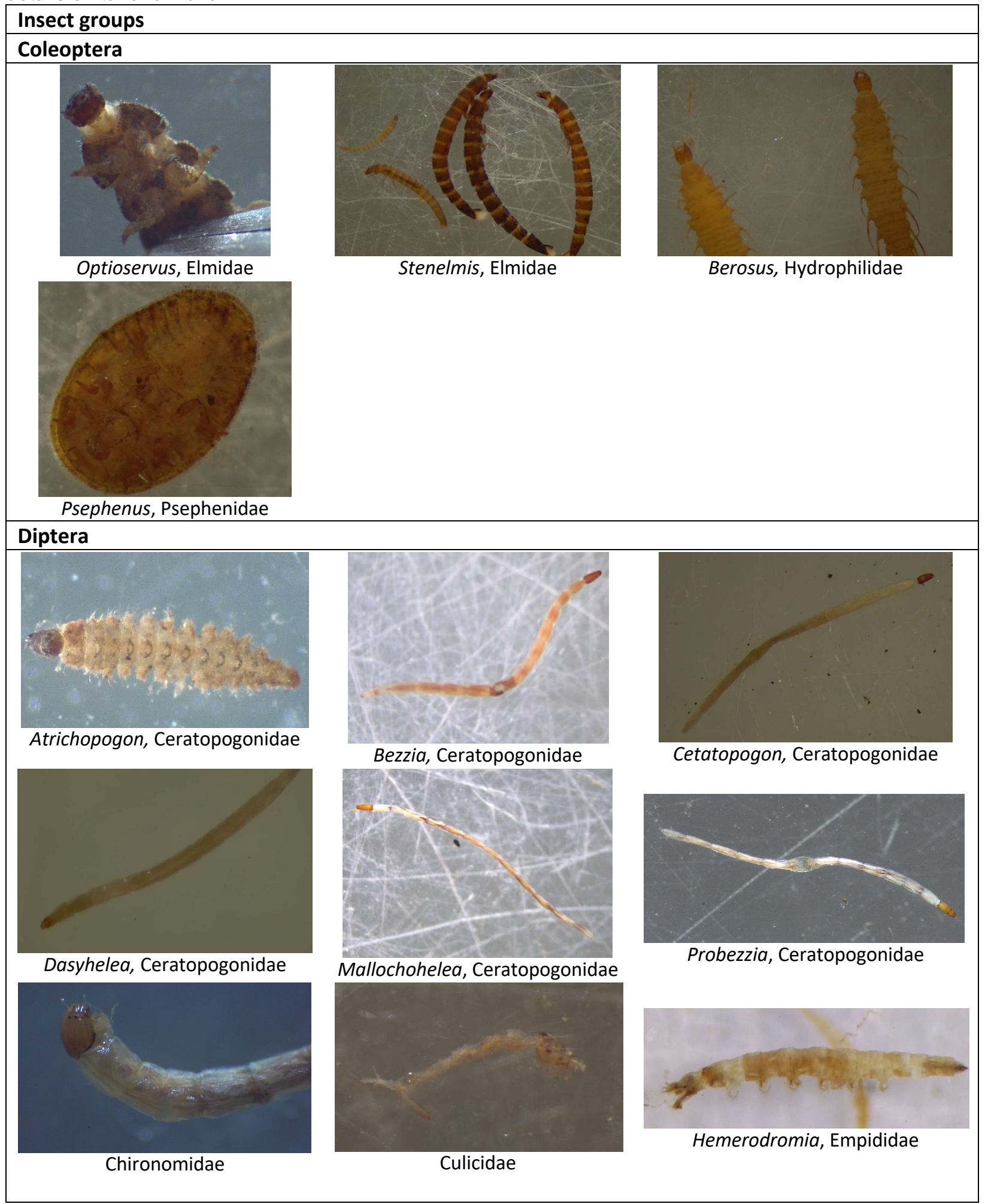




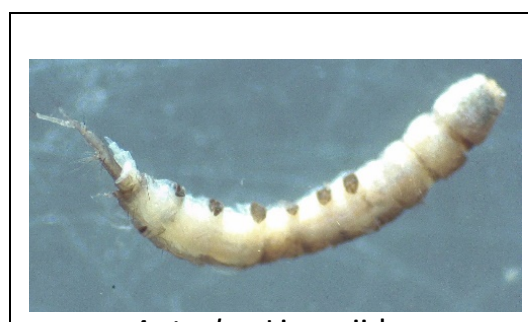

Antocha, Limoniidae

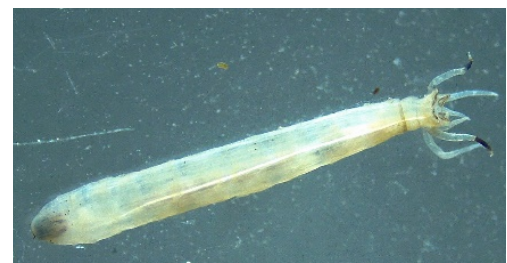

Tipula, Tipulidae

\section{Ephemeroptera}

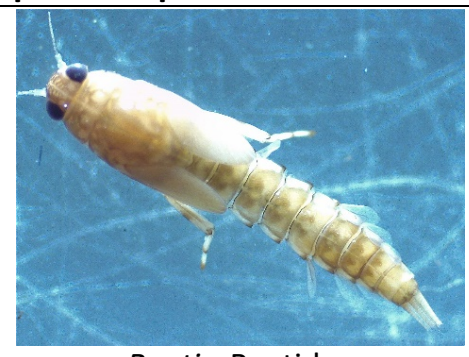

Baetis, Baetidae

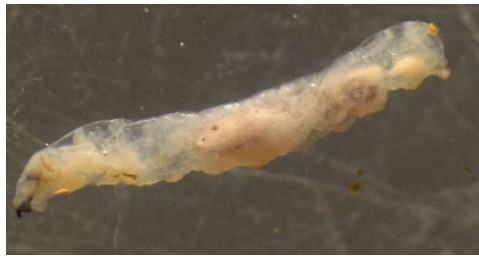

Muscidae

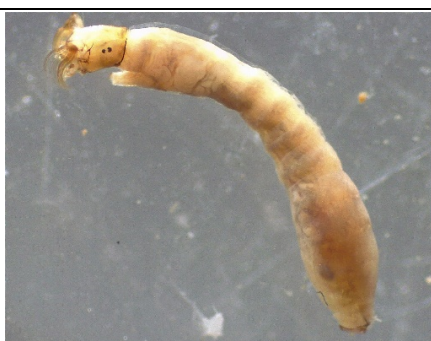

Simulium, Simulidae

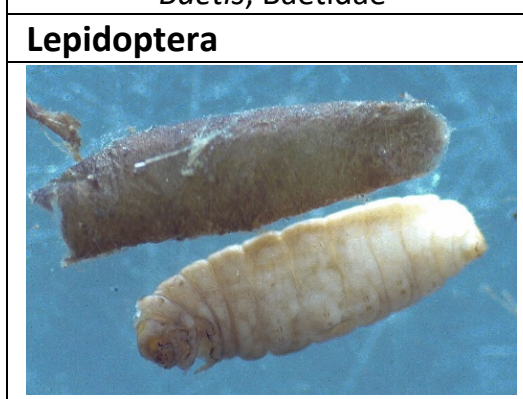

Elophila, Crambidae

\section{Megaloptera}



Nigronia, Corydalidae

Nigronia, Corydalidae
Maccaffertium, Heptageniidae
Pyralidae
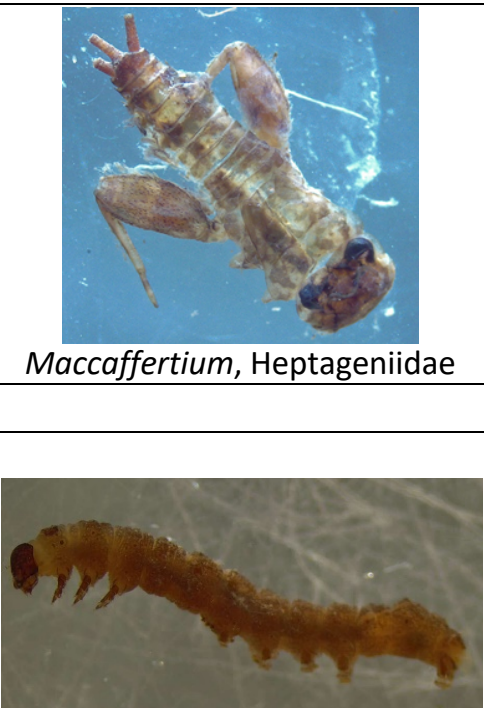



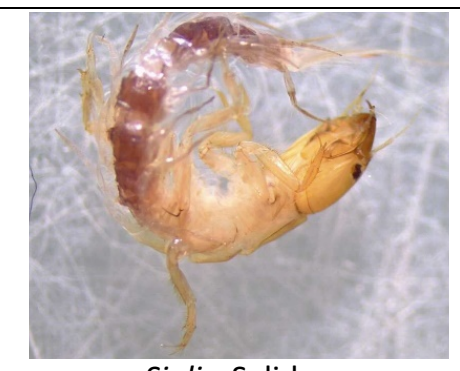

Sialis, Salidae 


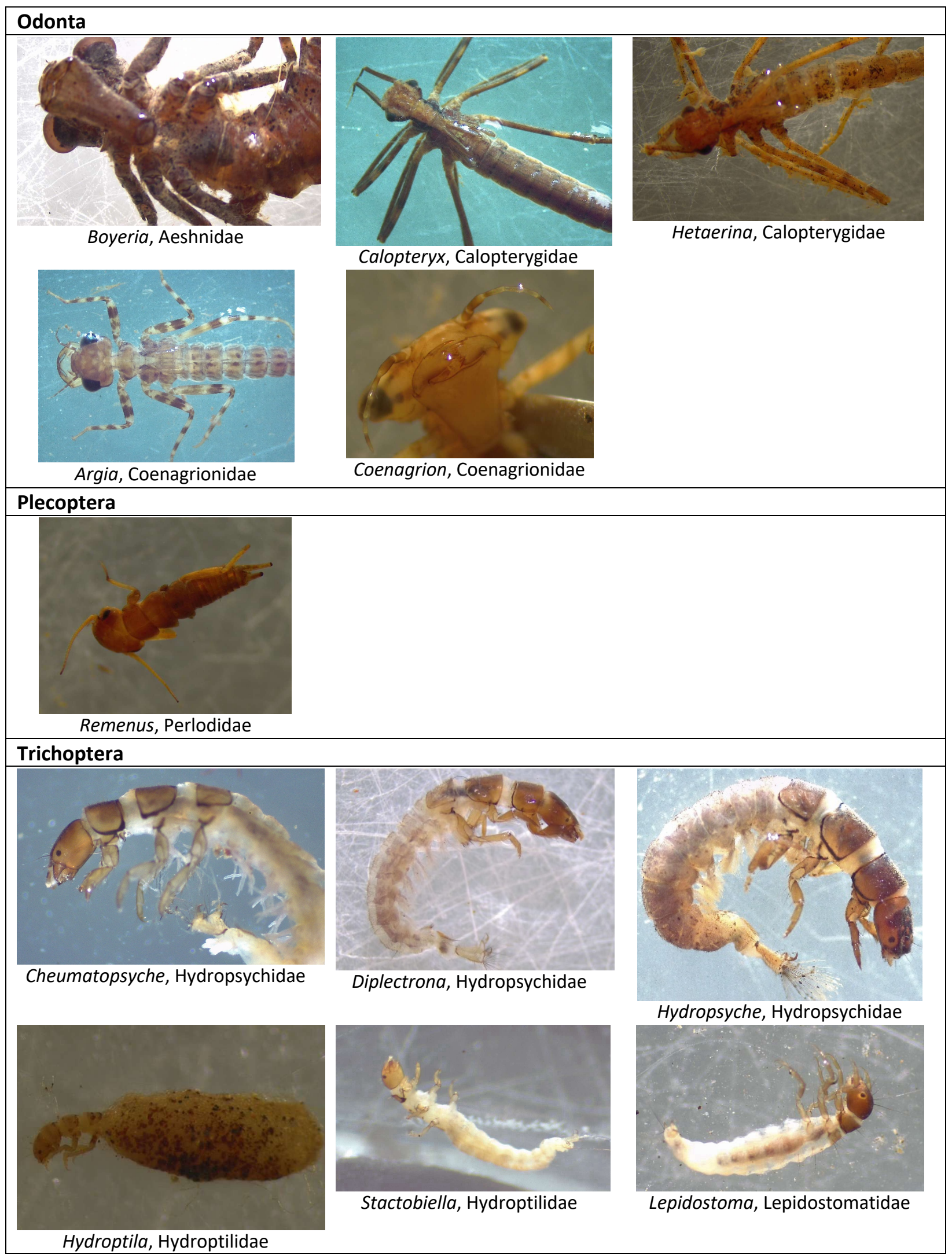











Figure A2. Average relative abundances per site of the full dataset. 37 insect groups and 10 non-insect groups were identified. Hydropsychidae and Chironomidae were the most abundant families found in WRW. 

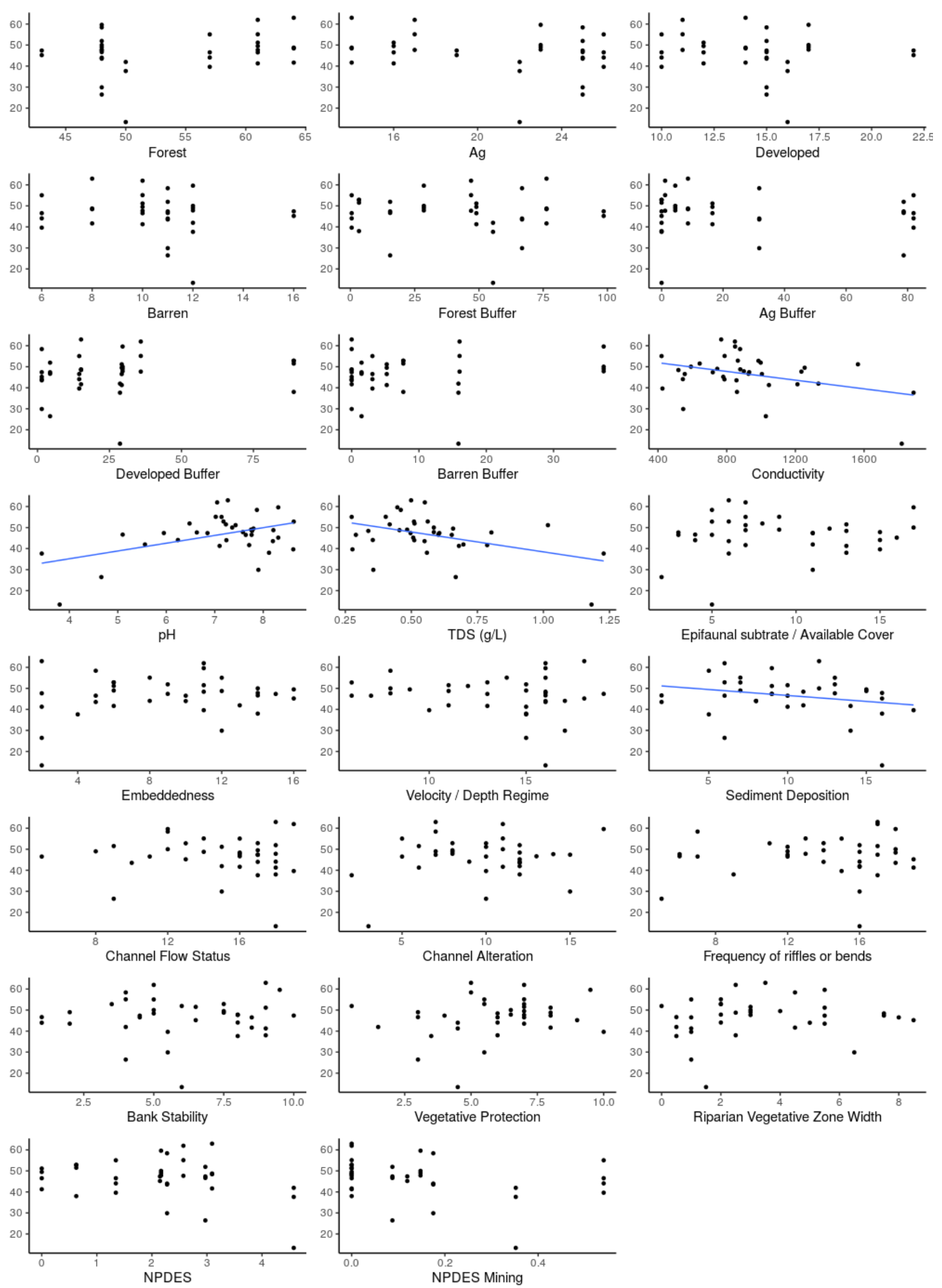

Figure A3. WVSCl scores of all sites in all years plotted against 23 environmental variables. Solid blue regression lines indicate statistically significant $(\alpha=0.05)$ relationship after adjusting for multiple tests (via Benjamini-Hochberg method), dashed blue lines indicate statistically significant relationship $(\alpha=0.05)$ for individual regression, and dashed red lines indicate a statistical trend $(\alpha=0.1)$ for the individual regression. Conductivity, $\mathrm{pH}$, TDS, and Sediment deposition were significant predictors of WVSCl. $\mathrm{pH}$ was the only predictor positively correlated with WVSCI. See Table 6 for slopes based on repeated measures ANOVA. 

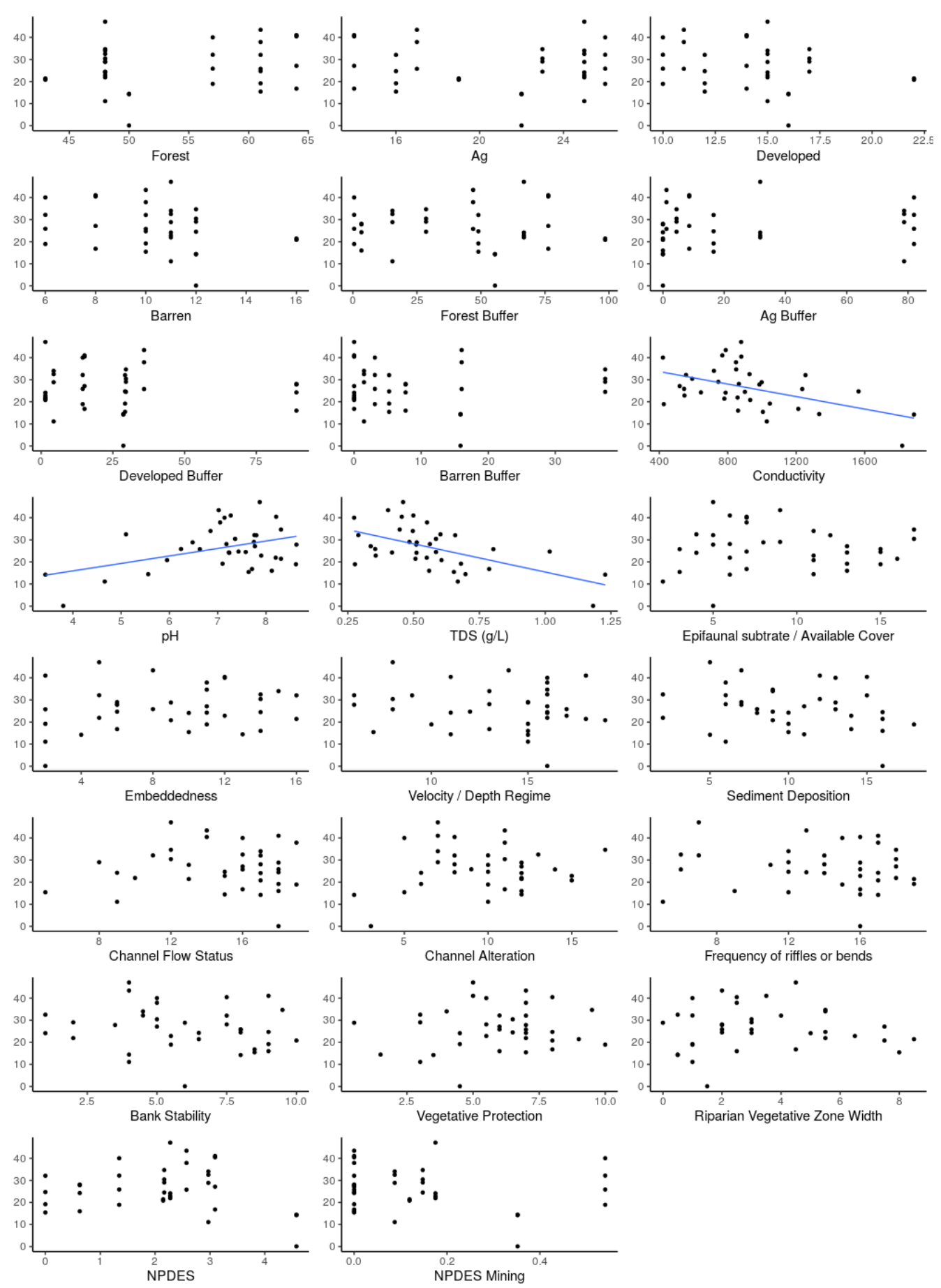

Figure A4. GLIMPSS (CF) scores of all sites in all years plotted against 23 environmental variables. Solid blue regression lines indicate statistically significant $(\alpha=0.05)$ relationship after adjusting for multiple tests (via Benjamini-Hochberg method), dashed blue lines indicate statistically significant relationship $(\alpha=0.05)$ for individual regression, and dashed red lines indicate a statistical trend $(\alpha=0.1)$ for the individual regression. Conductivity, $\mathrm{pH}$, and TDS were significant predictors of GLIMPSS (CF). $\mathrm{pH}$ was the only predictor positively correlated with GLIMPSS (CF). See Table 6 for slopes based on repeated measures ANOVA. 

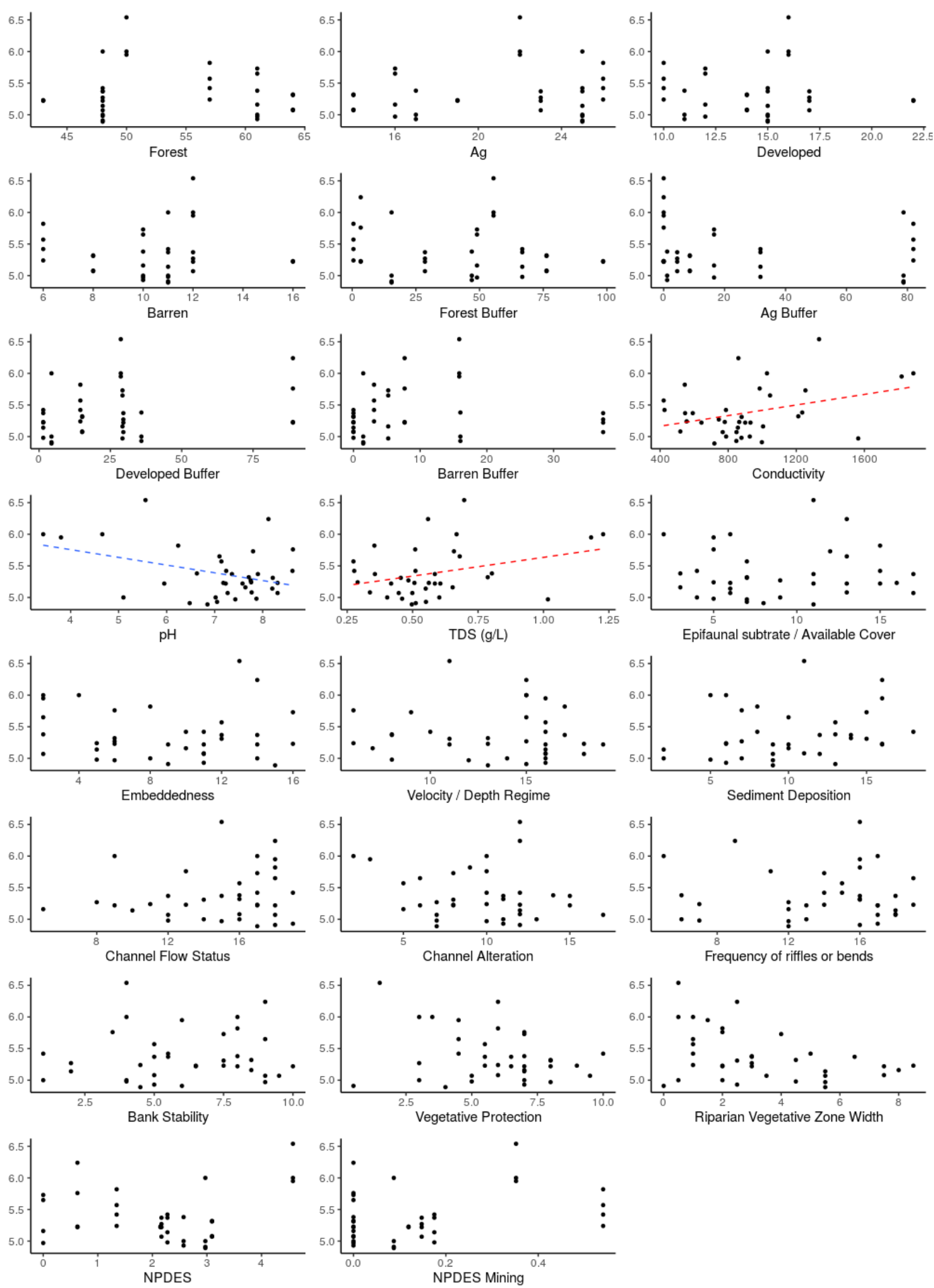

Figure A5. Family BI scores of all sites in all years plotted against 23 environmental variables. Solid blue regression lines indicate statistically significant $(\alpha=0.05)$ relationship after adjusting for multiple tests (via Benjamini-Hochberg method), dashed blue lines indicate statistically significant relationship $(\alpha=0.05)$ for individual regression, and dashed red lines indicate a statistical trend $(\alpha=0.1)$ for the individual regression. Low $\mathrm{BI}$ scores indicate there are more intolerant taxa present. $\mathrm{pH}$ was the only environmental variable to improve stream condition. See Table 6 for slopes based on repeated measures ANOVA. 

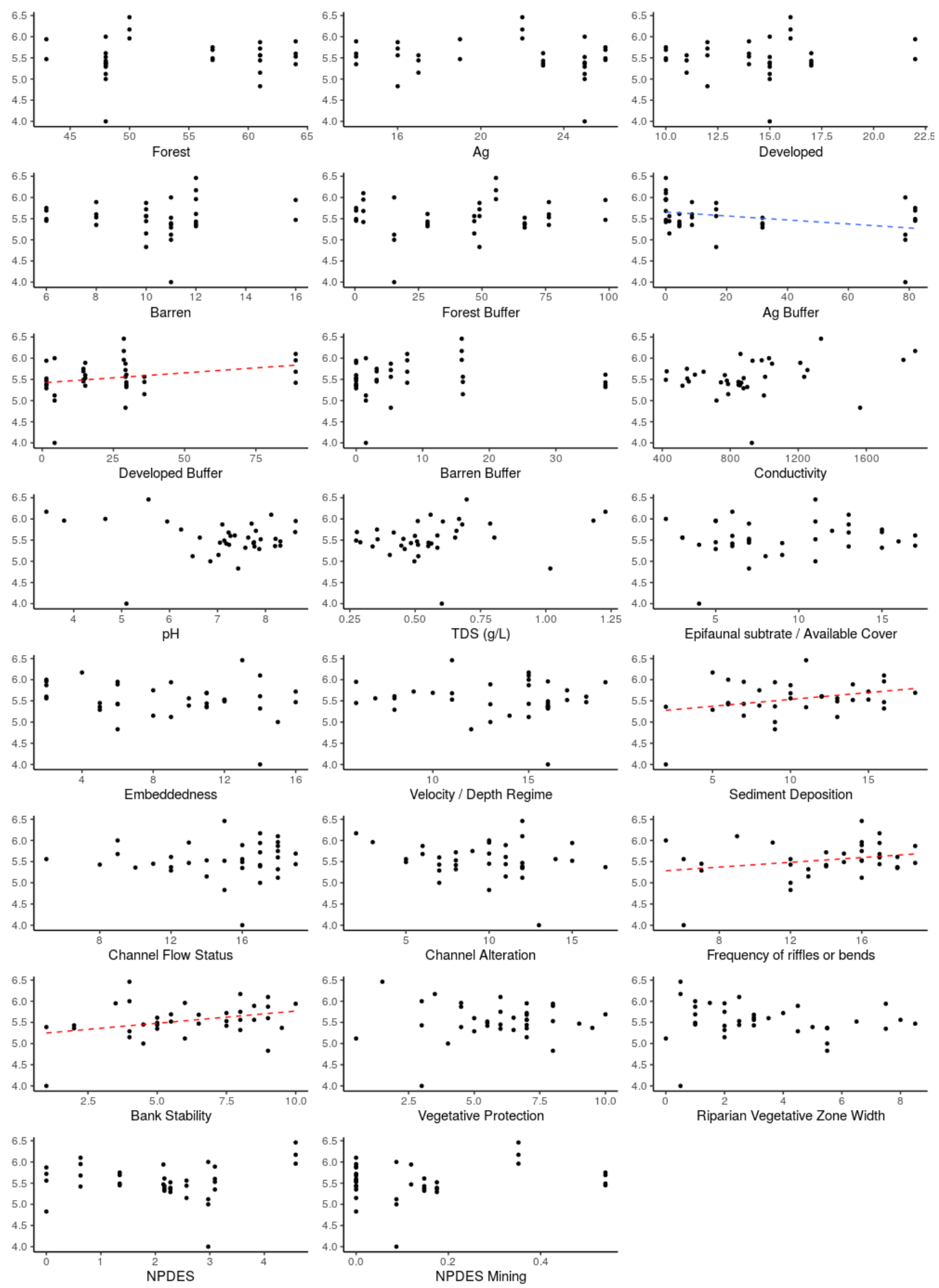

Figure A6. Genus BI scores of all sites in all years plotted against 23 environmental variables. Solid blue regression lines indicate statistically significant $(\alpha=0.05)$ relationship after adjusting for multiple tests (via Benjamini-Hochberg method), dashed blue lines indicate statistically significant relationship $(\alpha=0.05)$ for individual regression, and dashed red lines indicate a statistical trend $(\alpha=0.1)$ for the individual regression. Low BI scores indicate there are more intolerant taxa present. \% $\mathrm{Ag}$ was the only environmental variable to improve stream condition. See Table 6 for slopes based on repeated measures ANOVA. 

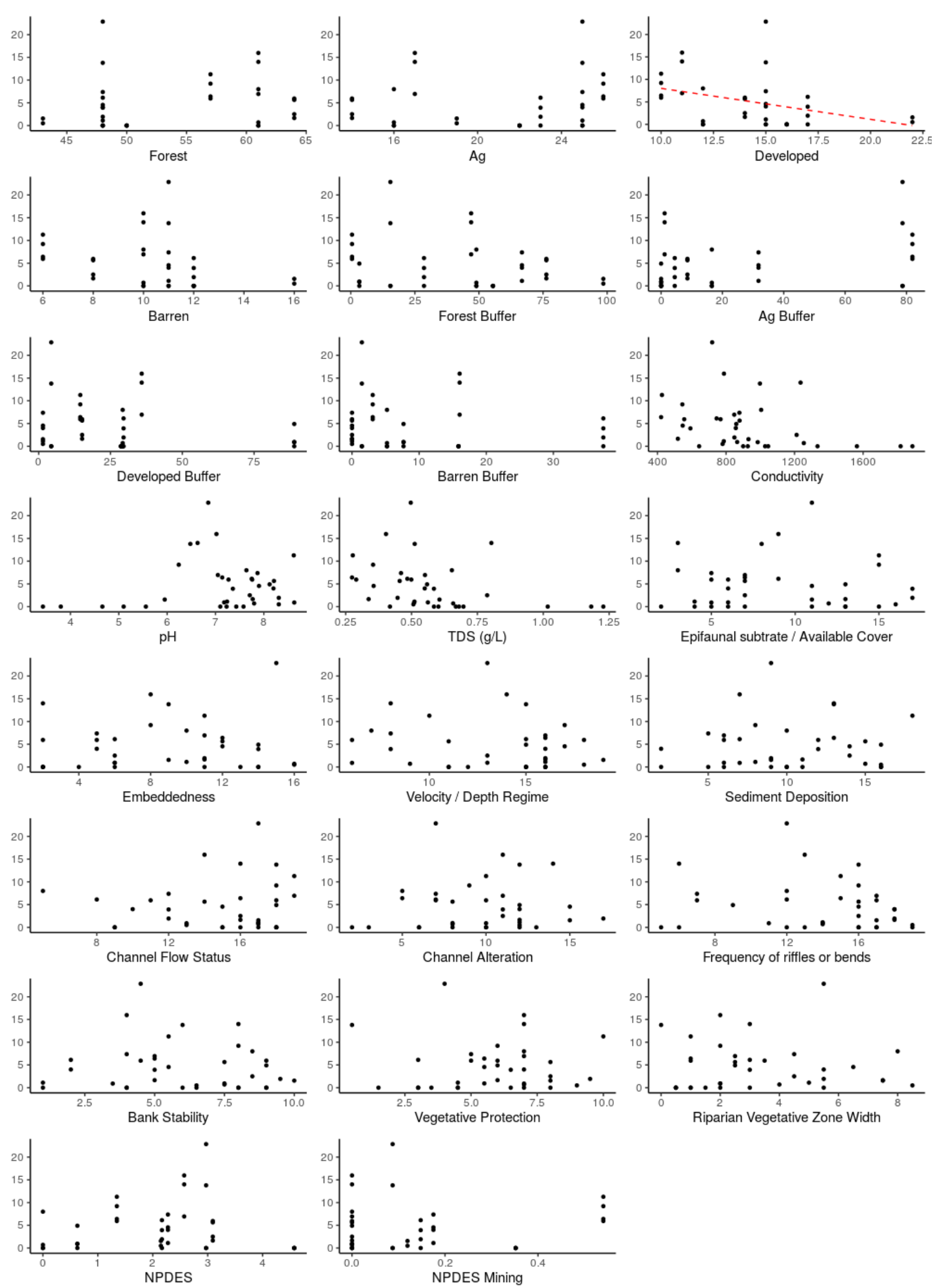

Figure A7. Percent scrapers of all sites in all years plotted against 23 environmental variables. Solid blue regression lines indicate statistically significant $(\alpha=0.05)$ relationship after adjusting for multiple tests (via Benjamini-Hochberg method), dashed blue lines indicate statistically significant relationship $(\alpha=0.05)$ for individual regression, and dashed red lines indicate a statistical trend $(\alpha=0.1)$ for the individual regression. Scrapers are expected to increase in response to development. There were no significant predictors. See Table 6 for slopes based on repeated measures ANOVA. 

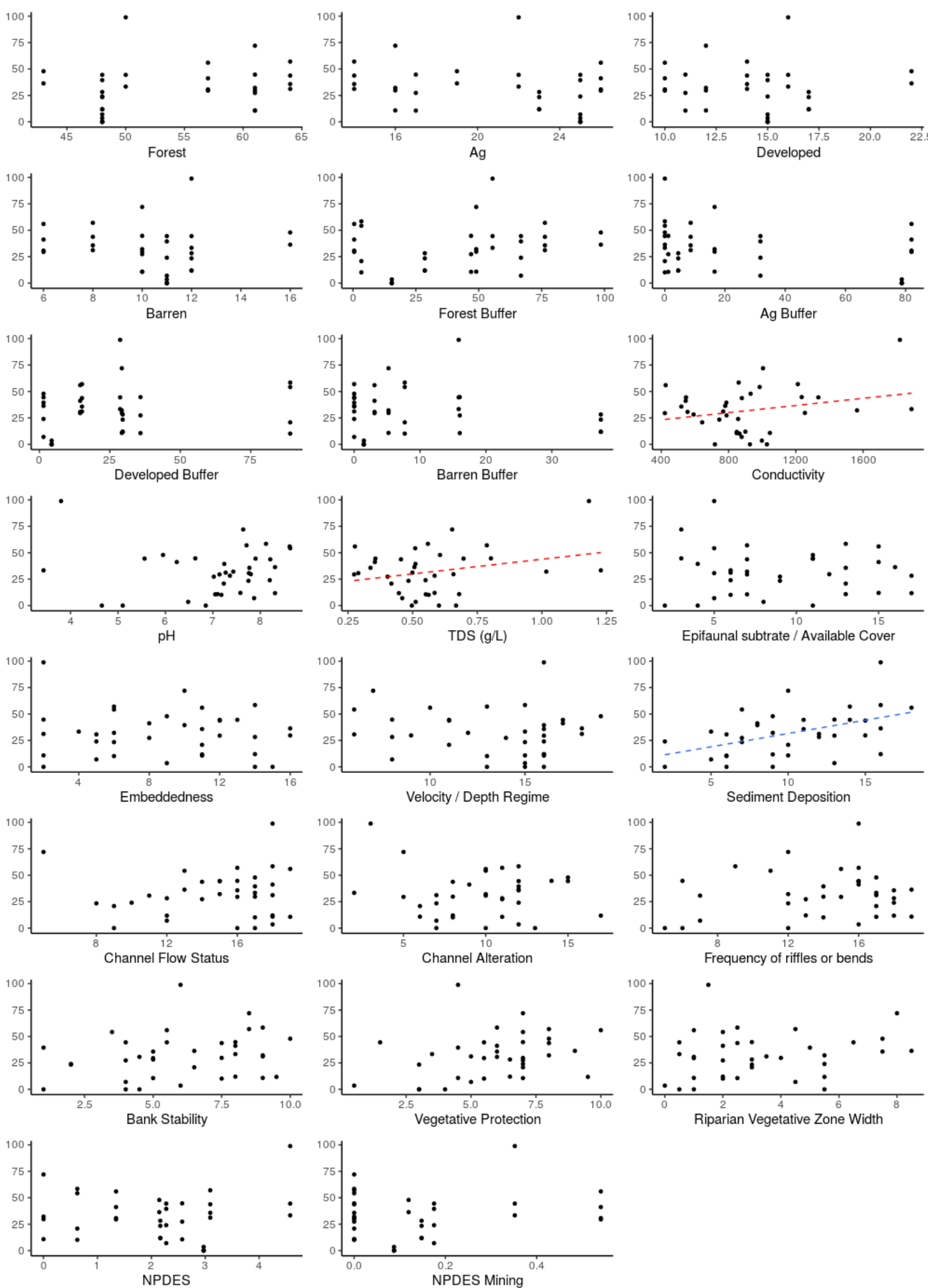

Figure A8. Percent burrowers of all sites in all years plotted against 23 environmental variables. Solid blue regression lines indicate statistically significant $(\alpha=0.05)$ relationship after adjusting for multiple tests (via Benjamini-Hochberg method), dashed blue lines indicate statistically significant relationship $(\alpha=0.05)$ for individual regression, and dashed red lines indicate a statistical trend $(\alpha=0.1)$ for the individual regression. Burrowers are expected to increase in response to development. Percent burrowers responded positively to less sediment deposition (higher number indicates more optimal habitat). See Table 6 for slopes based on repeated measures ANOVA. 

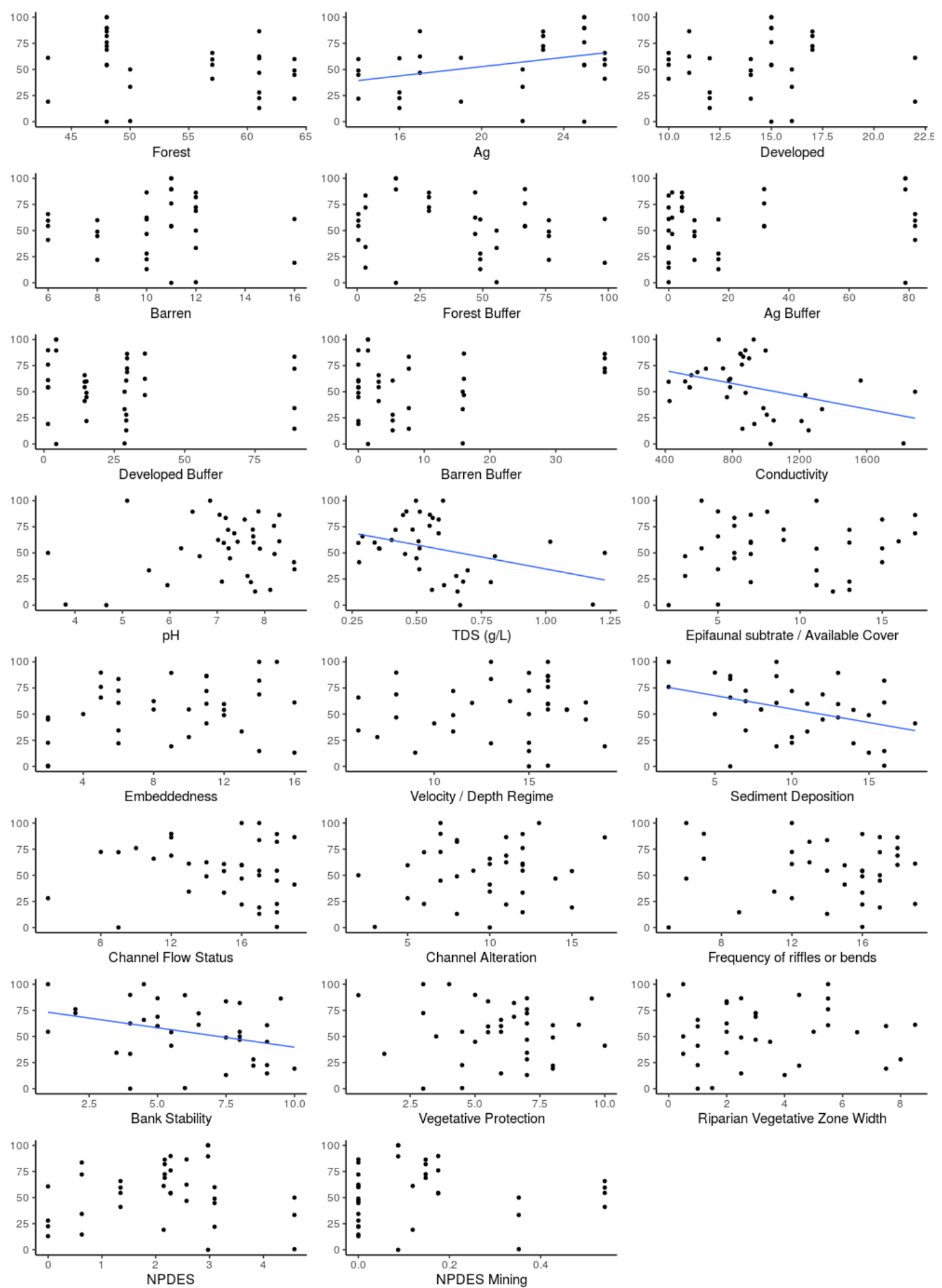

Figure A9. Percent clingers of all sites in all years plotted against 23 environmental variables. Solid blue regression lines indicate statistically significant $(\alpha=0.05)$ relationship after adjusting for multiple tests (via Benjamini-Hochberg method), dashed blue lines indicate statistically significant relationship $(\alpha=0.05)$ for individual regression, and dashed red lines indicate a statistical trend $(\alpha=0.1)$ for the individual regression. Clingers are expected to decrease in response to development. Percent clingers responded positively to $\%$ Ag). See Table 6 for slopes based on repeated measures ANOVA. 

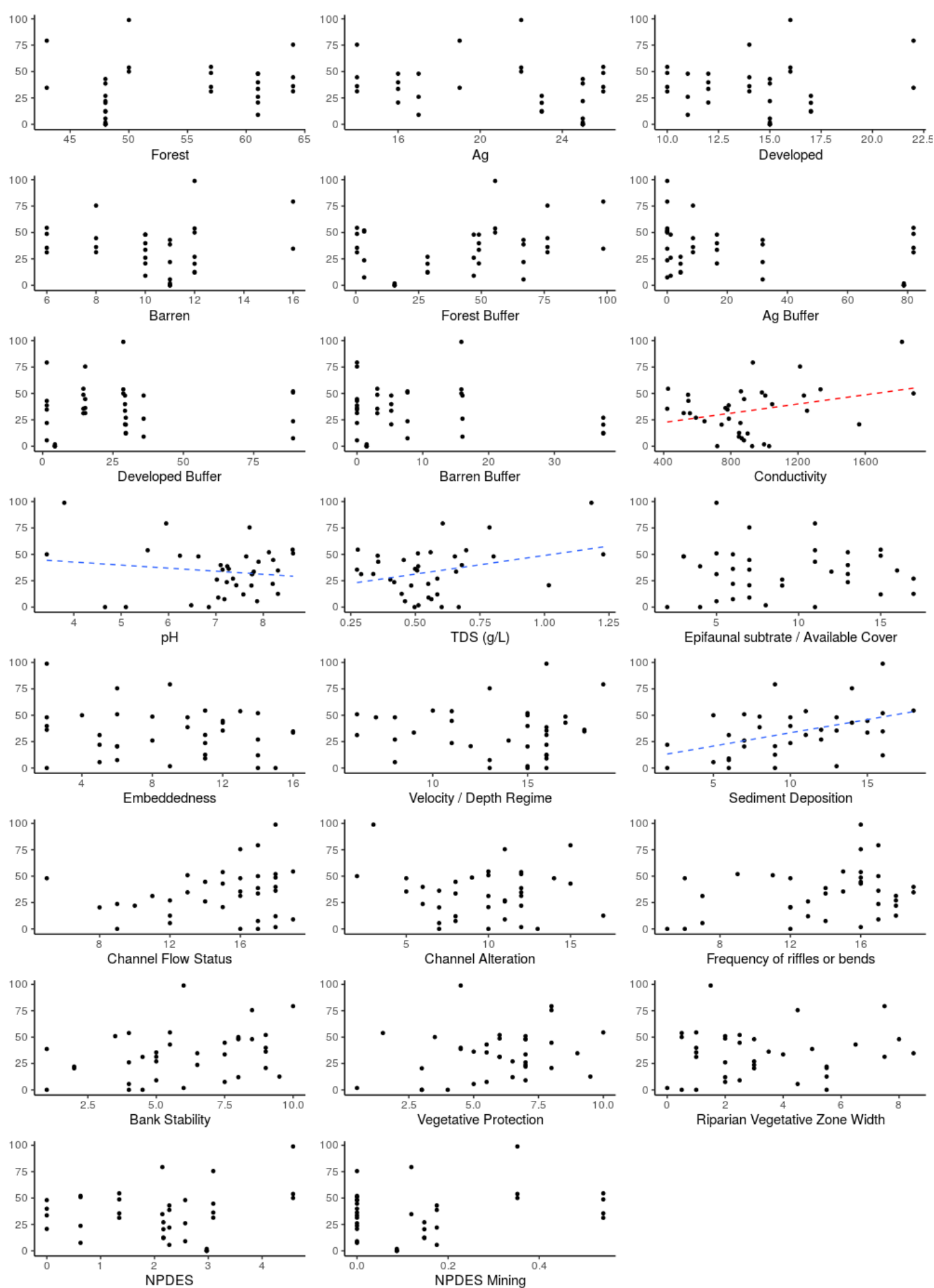

Figure A10. Percent collector-gatherers of all sites in all years plotted against 23 environmental variables. Solid blue regression lines indicate statistically significant $(\alpha=0.05)$ relationship after adjusting for multiple tests (via Benjamini-Hochberg method), dashed blue lines indicate statistically significant relationship $(\alpha=$ $0.05)$ for individual regression, and dashed red lines indicate a statistical trend $(\alpha=0.1)$ for the individual regression. Collector-gatherers are expected to increase in response to development. Percent collectorgatherers responded positively to higher TDS and less sediment deposition (higher number indicates more optimal habitat). See Table 6 for slopes based on repeated measures ANOVA. 

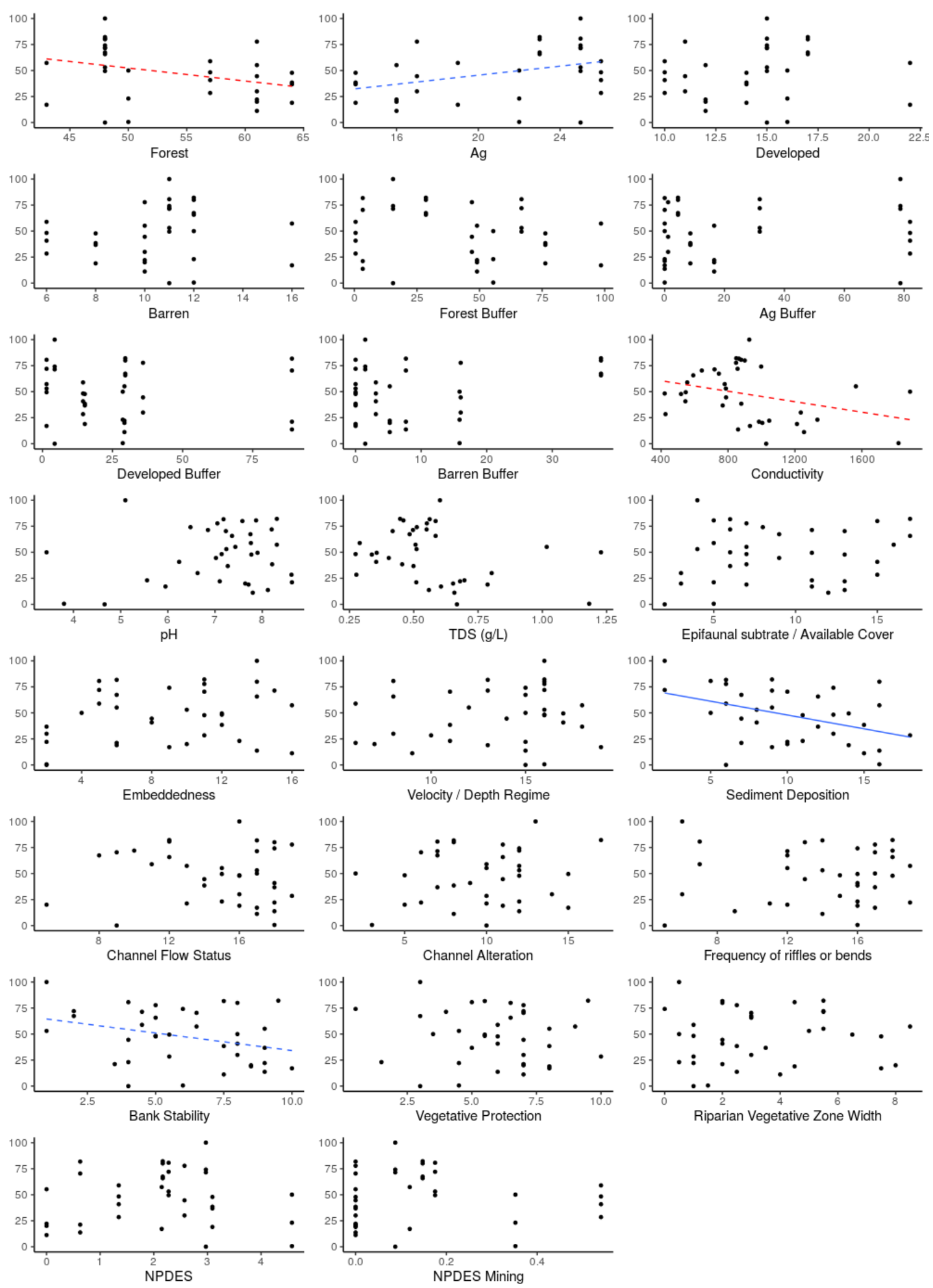

Figure A11. Percent collector-filterers of all sites in all years plotted against 23 environmental variables. Solid blue regression lines indicate statistically significant $(\alpha=0.05)$ relationship after adjusting for multiple tests (via Benjamini-Hochberg method), dashed blue lines indicate statistically significant relationship $(\alpha=$ 0.05 ) for individual regression, and dashed red lines indicate a statistical trend $(\alpha=0.1)$ for the individual regression. Collector-filterers are expected to decrease in response to development. Percent collectorfilterers responded positively to \% Ag. See Table 6 for slopes based on repeated measures ANOVA. 